\title{
BIBLIOGRAPHY OF BRYOLOGICAL RESEARCH IN HUNGARY (1968-2018)
}

\author{
József NagY ${ }^{1}$, Anna Pap-Kovács ${ }^{2} \&$ Peter Erzberger ${ }^{3}$ \\ ${ }^{1}$ H-1037 Budapest, Domoszló u. 22, Hungary; nagyjozsef.botanika@gmail.com \\ ${ }^{2} H-8196$ Litér, Bajcsy-Zsilinszky u. 53, Hungary \\ ${ }^{3}$ Belziger Str. 37, D-10823 Berlin, Germany
}

Nagy, J., Pap-Kovács, A. \& Erzberger, P. (2019): Bibliography of bryological research in Hungary (1968-2018). - Studia bot. hung. 50(1): 53-106.

\begin{abstract}
Our aim was to compile the register of bryological publications from the period 19682018 with some references to Hungary, research done in Hungary or on material collected in Hungary. We screened the contents of twenty Hungarian and several international scientific journals. Apart from traditional methods of compilation we also reviewed online databases, published biographies with corresponding bibliographies, and used personal contacts with researchers to obtain their relevant publications. As a result of our efforts we present here a synopsis of 835 publications of various types (books, parts of books, scientific articles, bibliographies, abstracts of lectures, articles in popular scientific journals, manuscripts), sorted according to the year of publishing.
\end{abstract}

Key words: ecophysiology, floristics, list of publications, liverworts, mosses

\section{INTRODUCTION}

In 1968, fifty-one years ago, Ádám Boros published his comprehensive book entitled Bryogeographie und Bryoflora Ungarns, which contains the last extensive register of the bryological literature concerning Hungary of the previous period. During the following decades, but in particular during the last twenty years, the results of bryological research related to Hungary have appeared in a continuously growing number of publications. Thus time has arrived for a renewed systematic compilation. Our aim was to establish the syllabus of references to the extraordinarily diversified Hungarian research in bryology of the period 19682018, the last 51 years.

\section{MATERIAL AND METHODS}

Apart from bryofloristical research in continuation of great traditions, and the fields of ecophysiology and ecology of bryophytes, which have grown important during the last 30 years, we have also compiled papers on bryophyte associations and vegetation, nature conservation, taxonomy, anatomy, palaeobotany, 
population genetics, pharmacology, history and politics of science and other relevant areas.

Apart from scientific publications in Hungarian and international journals, we also compiled relevant parts of students handbooks, determination tables or easy-to-read scientific articles. The types of publications comprise books, parts of books, scientific articles, bibliographies, summaries/abstracts, articles in popular scientific journals, manuscripts (doctoral and diploma theses, research reports).

As a starting point we used the compilation of the senior author (P.E.). We consulted biographic accounts with corresponding bibliography of the following: Ádám Boros (BOROSNÉ-KENYERES \& ORBÁN 1976), László Vajda (RAJCZY 1987), Zoltán Tuba (downloaded from an expired link: http://bdi.szie.hu/ node/40), Sándor Orbán (PÉNZEs-KónYa et al. 2017), and Tamás Pócs (OrbáN \& PÉNZES-KóNYA 2013). The thematic bibliography of SZURDOKI (2000) complements our compilation, we did not feel the necessity to re-evaluate its complete contents.

We screened the tables of contents of 20 Hungarian and two international scientific journals. For this purpose, we used some online tools and databases, e.g. http://epa.oszk.hu, http://real.mtak.hu, http://www.okologia.mta.hu, http:// www.matarka.hu, https://adtplus.arcanum.hu, http://www.jstor.org/stable.hu, https://library.hungaricana.hu, as well as online databases of universities and museums.

During our research we used the cumulative index of all references that appeared in Journal of Bryology (1972-2018) and Field Bryology (2004-2018) prepared by Philip Stanley (http://www.lumiweb.com/download_allrefs.htm). In addition, we evaluated the abstract books of the following scientific events:

- Advances in research on the flora and vegetation of the Carpatho-Pannonian region (Aktuális Kárpát-medencei flóra- és vegetációkutatás konferenciák),

- Congresses of Hungarian Ecologists (Magyar Ökológus Kongresszusok)

- Hungarian conferences on the biology of nature conservation (Magyar Természetvédelmi Biológia konferenciák).

In the case of five researchers we downloaded and selected the relevant publications from the website sustained by the Hungarian Academy of Sciences (Magyar Tudományos Mủvek Tára, https://www.mtmt.hu). We addressed six renowned scholars personally and thus recieved from them directly the lists of publications dealing with Hungarian bryological research.

As a result of our efforts we present the register of 835 scientific and popular scientific publications, sorted according to the year of print. 


\section{ENUMERATION}

Boros Á. (1915-1971): Florisztikai jegyzetek. - manuscript, Magyar Természettudományi Múzeum, Budapest.

VAJDA L. (1933-1978): Florisztikai jegyzetek [Field diaries]. - manuscript, Magyar Természettudományi Múzeum, Tudománytörténeti gyüjtemény, Budapest.

\section{8}

Boros Á. (1968): Bryogeographie und Bryoflora Ungarns. - Akadémiai Kiadó, Budapest, 466 pp.

Boros Á. (1968): Mohák. - In: HorToBÁgy T. (ed.): Növényhatározó I. Baktériumok-Mohák. Tankönyvkiadó, Budapest, pp. 567-612.

Boros Á. \& VAJDA L. (1968): A Bakony-hegység lápjainak mohaföldrajza. (Moosgeographie der Moorgebiete des Bakony-Gebirges). - Veszprém megyei Múz. Közl. 7: 187-192.

DEBRECZY Zs. (1968): A mohafajok szerepe a Balatonfelvidék egy területének vegetációs szukcessziójában. (Die Rolle der Moosarten in der Vegetations-Sukzession eines Gebietes des Balatonoberlandes). - Fragmenta bot. Mus. hist.-nat. hung. 6: 59-66.

Nagy E. (1968): Moss spores in Hungarian Neogene strata. - Acta Bot. Acad. Sci. Hung. 14(1-2): $113-132$.

Pócs T. (1968): XIII. Törzs: Mohák. Bryophyta. - In: HoRToBÁGyi T. (ed.): Növénytan 2, Növényrendszertan és növényföldrajz. (Phytotaxonomy and phytogeography). Tankönyvkiadó, Budapest, pp. 190-211.

Simon T. (1968): Die Torfmoor-Gesellschaften Ungarns. - Acta Universitatis Debreceniensis de Ludovico Kossuth nominatae. Series Geographica Geologica et Meteorologica 7(14): 201-206.

VAJDA L. (1968): A Szigligeti Arborétum mohái. (Die Moose des Arboretums Szigliget). - Veszprém megyei Múz. Közl. 7: 237-240.

VöRöss L. Zs. (1968): Domb- és hegyvidéki növények a Dráva-síkon és más florisztikai adatok. Bot. Közlem. 55: 185-186.

\section{9}

Balogh M. (1969): Megyénk természeti értékei. Az öcsi Nagy-tó. - Napló [Veszprém] 25(266): 8. Boros Á. (1969): A mohák rendszere. - In: KÁRpÁti Z. (ed.): A növények világa II. - Gondolat Könyvkiadó, Budapest, pp. 89-105.

VAJDA L. (1969): A Sátorhegység mohaflórája. (Die Moosflora des Sátorgebirges). - Fragmenta bot. Mus. hist.-nat. hung. 7: 93-120.

VAJDA L. (1969): A magyarországi leveles májmohák határozókulcsa. Jungermanniae acrogynae. (Bestimmungstabelle der beblätterten Lebermoose. Jungermanniae acrogynae). - Fragmenta bot. Mus. hist.-nat. hung. 7: 121-134.

Vöröss L. Zs. (1969): Mohok és harasztok az abaligeti barlangban, villanyfényben. (Moose und Farne bei elektrischem Licht in der Höhle von Abaliget). - Bot. Közlem. 56(3): 176.

\section{0}

Boros Á. (1970): Für Ungarn neue und interessante Moose V. - Bot. Közlem. 57: 80.

Boros Á. (1970): Florisztikai Közlemények V. (Floristische Mitteilungen V). - Bot. Közlem. 57(1): 69-72.

Boros Á. (1970): Barna Györffy (1911-1970). - Rev. Bryol. 37: 397. 
Boros Á. (1970): Tápiószele környéke flórájának virágosnövény- és mohaérdekességei. (Interessantere Blütenpflanzen und Moose in der Flora der Umgegend von Tápiószele). - Agrobotanika 10: $247-251$.

Boros Á. \& VAjDa L. (1970): Für die Flora Ungarns neue und interessante Moose V. - Ann. Hist.nat. Mus. Nat. Hung. 62: 149-152.

Hevesi A. (1970): Az algák és a mohák szerepe a bükki forrásmészkő képződésében. - Bot. Közlem. 57(3): 233-244.

Simon T. (1970): Bryocönológiai és ökológiai adatok a Zempléni-hegységből. (Bryozönologische und ökologische Angaben aus dem Zempléner Gebirge). - Bot. Közlem. 57(1): 31-43.

Simon T. (1970): Tőzegmohás növénytársulások új előfordulása a Tátika-Kovácsi hegycsoportban. (Elözetes közlemény). (Neues Vorkommen von torfmoosreicher Pflanzengesellschaften in den Bergen Tátika-Kovácsi. (Vorläufige Mitteilung)). - Bot. Közlem. 57(3): 200.

\section{1}

Boros Á. (1971): A barlangok felsőbbrendủ növényvilága. - Karszt és Barlang 1971(2): 49-52.

Boros Á. (1971): Látszólagos ellentmondások néhány xerophyton moha kárpáti, kárpát-medencei és horvátországi elterjedésében. (Paradoxa in der Verbreitung einiger xerophytischen Moose der Karpaten, der Karpatenbecken und Kroatiens). - Bot. Közlem. 58: 125-129.

Boros Á. (1971): A mohák jelentősége a mezőgazdaságban. - Agrobotanika 12: 99-106.

GALLÉ L. (1971): Epiphytenvegetation der Weisspappelstämme von den sandbindenden Wäldern der Grossen Ungarischen Tiefebene. - Móra F. Múz. Évk. 1971: 15-35.

Simon T. (1971): Mohagazdag szilikátgyepek a Zempléni hegységben. (Moosreiche Silikat-Felsenrasen in dem Zempléner-Gebirge). - Bot. Közlem. 58(1): 33-45.

VAJDA L. (1971): Bryologiai közlemények. 1-2. (Bryologische Mitteilungen. 1-2). - Bot. Közlem. 58(1): 29-31.

Vöröss L.Zs. (1971): Az Abaligeti-barlang villanyfényben élö mohai és harasztjai. - Pécsi Müszaki Szemle 14: 17-23.

VöRöss L.Zs. (1971): Néhány újabb adat Baranya flórájához II. (Neue Beiträge zur Flora von Baranya (Südungarn). - Bot. Közlem. 58: 46.

\section{2}

Boros Á. (1972): A magyarországi és kárpáti barlangok felsőbbrendủ növényzetére vonatkozó irodalom. - Karszt és Barlangkutatási tájékoztató 2: 20-22.

Boros Á. \& SzABó L. (1972): A levegőszennyeződés első áldozatai a zuzmók és a mohák. - Természet Világa 103(10): 456-458.

Simon T. \& Kovács-LÁNG E. (1972): Produkcióbiológiai vizsgálatok a csévharaszti IBP mintaterületen. - MTA Biol. Oszt. Közl. 15: 61-69.

Simon T. \& OrbÁn S. (1972): Untersuchungen der Assimilationsfläche und des Chlorophyllgehalts des Festuca vaginata Rasens und der Roggensaat. - Ann. Univ. Sci. Budapest 14: 165-167.

\section{3}

Debreczy, Zs. (1973): A Balaton-felvidéki Péter-hegy és környéke cönológiai vizsgálata. (The coenological investigations of Péter-hegy (Mountain) and its environs in the Balaton Upland). - A Veszprém Megy. Múz. Közlem. 12: 191-220. 
GALLÉ L. (1973): Kryptogám növénytársulások a szegedi körtöltés téglaburkolatán. - Studia bot. bung. 8: 25-32.

Kiss E. Cs., Borhidi A. \& VAJDA L. (1973): Sphagnum fajok elöfordulása a Velencei tavon. (Sphagnum-Arten am Velenceer See). - Bot. Közlem. 60(1): 25-26.

Orbán S. \& Debreczy Zs. (1973): Moos-arealgeographische Studien aus dem Gebiet der Karpaten und Karpatenbecken I. - Studia bot. hung. 8: 65-98.

Simon T. (1973): Megemlékezés Boros Ádámról (1900-1973). - Bot. Közlem. 60(1): 3-5.

Simon T. (1973): Brachyodontium trichodes (Web. f.) Bruch Síkfökút közelében. - Bot. Közlem. 60(3): 163-166.

VAJDA L. (1973): Prof. Dr. Ádám Boros (1900-1972). - Rev. bryol. lichenol. 39: 495-496.

\section{4}

Domina L. (1974): Kisbér és Ácsteszér mohái. - A tatai Herman Ottó Kör munkái 4: 113-116.

JÁRAI-KomLóDI M. (1974): Comparative spore morphological examinations in Funaria and Physcomitrium species. - Acta Bot. Hung. 20(1-2): 71-81.

MÉszáros I. (1974): Tata mohái I. - A tatai Herman Ottó Kör munkái 4: 117-118.

OrbÁN S. (1974): Moos-arealgeographische Studien aus dem Gebiet der Karpaten und Karpatenbecken II. - Studia bot. hung. 9: 43-70.

Orbán S. (1974): A Mniaceae család fajainak elterjedése a Kárpátok és a Kárpát-medence területén. - Doktori értekezés, ELTE, TTK, Budapest, 161 pp.

Pócs T. (1974): Bryological research in Hungary. - Taxon 23: 882-883.

Simon T. (1974): Mohák, zuzmók, harasztok (Búvár zsebkönyvek). - Móra Könyvkiadó, Budapest, $64 \mathrm{pp}$.

Simon T. (1974): Estimation of phytomass dry-weight of epiphytic mosses at Síkfókút (near Eger, N Hungary). - Acta Bot. Hung. 20(3-4): 341-348.

\section{5}

Bakalár S.-né, Orbán S., Pócs T., Suba L. \& Vajda L. (1975): Adatok a Tarnavidék mohaflórájához. (Daten zur Moosflora des Tarna-Gebiets). - Stud. bot. hung. 10: 111-114.

Boros Á. \& JÁrai-KomLódi M. (1975): An atlas of recent European moss spores. - Akadémiai Kiadó, Budapest, 465 pp.

Delgadillo C. (1975): Taxonomic revision of Aloina, Aloinella and Crossidium (Musci). - Bryologist 78: 245-303. https://doi.org/10.2307/3241887

ORBÁN S. (1975): Moos-arealgeographische Studien aus dem Gebiet der Karpaten und Karpatenbecke III. - Studia bot. hung. 10: 63-109.

Simon T. (1975): Nowellia curvifolia (Dicks.) Mitt. a Bakonyban és más adatok a hazai mohaflórához. - Abstr. Bot. 3: 105-111.

SIMON T. (1975): Mosses as indicator organisms for soil conditions in steppe forest ecosystems. XII. Int. Bot. Congr. Abstr., Leningrad, p. 87.

SIMON T. \& SZERÉNYI G. (1975): Moss ecological investigation in the forest-steppe associations of the IBP-area at Csévharaszt. - Acta Bot. Hung. 21(1-2): 117-136.

VAJDA L. (1975): Bryologische Notizen IV. 1. Mnium blyttii Br. in den Südkarpaten. 2. Neue Daten zur Moosgeographie Ungarns. 3. Fissidens exiguus Sull. neu für Ungarn. - Studia bot. hung. 10: $119-122$. 


\section{6}

BArbalics I. J. (1976): Adatok a Vasi Hegyhát mohaflórájához. - Bot. Közlem. 63(1): 21-22.

Borosné-KenYeres J. \& OrBÁN S. (1976): Boros Ádám (1900-1973) tudományos dolgozatainak jegyzéke. - Studia bot. hung. 11: 107-119.

JÁrAi-Komlódi M. \& OrbÁN S. (1976): Spore morphological studies on recent European Encalypta species. - Acta Bot. Hung. 21(3-4): 305-345.

OlÁн B. (1976): A magyarországi Orthotrichumok (Musci) gyakorisága, morfológiai felépítése, fenológiai viszonyai. - Abstr. Bot. 4: 1-33.

OlÁн B. (1976): Az Orthotrichumok (Musci) elterjedése Magyarországon. - Abstr. Bot. 4: 83-129.

OlÁн B. (1976): A magyarországi Orthotrichumok (Musci) ökológiai tulajdonságai. - Abstr. Bot. 4: 67-82.

OlÁн B. (1976): A magyarországi Orthotrichumok (Musci) klasszifikációja és taxonómiai leírása. - Abstr. Bot. 4: 35-66.

Orbán S. (1976): Moos-arealgeographische Studien aus dem Gebiet der Karpaten und im Karpatenbecken IV. - Studia bot. hung. 11: 49-81.

Orbán S. (1976): A Riccia gougetiana Mont. és más érdekes Riccia fajok a Hortobágyon. - Bot. Közlem. 62(3): 197-201.

Orbán S. \& Pócs T. (1976): Rhodobryum ontariense (Kindb.) Kindb. in central Europe. - Acta Bot. Hung. 22(3-4): 447-448.

Pócs T. (1976-1977): Type catalogue of the Bryophyte Herbarium of Ho Si Minh Teachers' College, Eger, Hungary. (Az egri Ho Si Minh Tanárképző Főiskola mohagyüjteményének típuskatalógusa). - Folia Hist.-nat. Mus. Matr. 4: 15-36.

Szujkó-Lacza J., Kováts D., Orbán S., Verseghy K., Komáromi Zs. \& Hajdu L. (1976): Néhány egyszerű módszer a Hortobágyi Nemzeti Park növényfajainak és vegetációjának tanulmányozásához. (Some simple methods for studying the species and vegetation of Hortobágy National Park (HNP)). - Studia bot. hung. 11: 83-106.

\section{7}

DÉZSI L. \& Simon T. (1977): Investigation of the K-, Ca-, P-, N- and amino acid content of the epiphitic Hypnum cupressiforme. (Síkfókút Project No. 16). - Acta Botanica 22(1-2): 17-28.

DömötöRnÉ SzILÁGYi J. (1977): A sejtfal cellulóz-vázszerkezete a Marchantia polymorpha L. gametophytonjában. (Die Zellulose-Skelettstruktur der Zellwand in der Gametophyt der Art Marchantia polymorpha L.). - Bot. Közlem. 64(1): 5-11.

Dömötörné SzILÁgyi J. \& WojnÁrovits-HrapKa I. (1977): The cellulose skeleton structure in some cell types of the gametophyton of Marchantia polymorpha L. - Acta Botanica 23(1-2): 41-61.

GALlÉ L. (1977): Magyarország zuzmócönózisai. (Flechtenassoziationen in Ungarn). - Móra F. Múz. Évk. 1976-77: 429-493.

HAJdu L. (1977): The flora of the Hungarian caves. - Karszt és Barlang 1977(Special Issue): 39-42.

ORBÁN S. (1977): Moss-arealgeographischen Studien aus dem Gebiet der Karpaten und im Karpatenbecken V. - Studia bot. hung. 12: 41-54.

Orbán S. (1977): Die Dynamik von Moosgesellschaften im Hortobágy National Park. - Bryophytorum Bibliotheca 13: 661-680.

Sımon T. (1977): A Zempléni-hegység északi részének védendő flóra különlegességeiről. (Zum Naturschutz empfohlene floristische Merkwürdigkeiten des nördlichen Zempléner Gebirges). - Abstr. Bot. 5: 57-63. 
Simon T. (1977): Vegetationsuntersuchungen im Zempléner Gebirge. (Die Vegetation ungarischer Landschaften 7). - Akadémiai Kiadó, Budapest, 350 pp.

\section{8}

FRIDVALSZKY L. \& DÖMÖTÖRNÉ SZILÁGYi, J. (1978): Cellulose skeleton structure of the cell wall in the gametophyton of Marchantia polymorpha L. - II. Parenchyma cells. - Acta Botanica 24(1-2): 57-68.

Pócs T. (1978): Bryological workshop in Hungary, June 1978. Bulletin of Bryology XIV. - Taxon 27(4): 433.

Pócs T. (1978): Changes in Hungarian Bryology. Bulletin of Bryology XIV. - Taxon 27(4): 434-435.

Rajczy M. (1978): How does affect the cave environment on some mosses? - In: Hindák F. (ed.): Proceedings of the Cryptogamological Symposium of the Slovak Academy Sciences Smolenice 20.-23.3.1978, Slovenská botanická spoločnost pri SAV, Bratislava, pp. 261-271.

\section{9}

BAKALÁRNÉ SÜTŐ I. \& BALOGH M. (1979): Sphagnum girgensohnii, a Velencei-tó és hazánk újabb boreális flóraeleme. (Sphagnum girgensohnii, ein neues boreales Florenelement in Ungarn). - Bot. Közlem. 66(1): 11-14.

BARBALICS I. J. (1979): Vasvár környékének tőzegmoha előfordulásai. - Savaria, a Vas Megyei Múzeumok Értesitöje 9-10: 11-25.

FRITSCH R. (1979): Chromosome numbers of some Hungarian liwerworts. - Abstr. Bot. 5(Suppl. 3): 75-78.

Galambos I. (1979): A Fontinalis hypnoides Hartm. új termőhelye. Rövid közlemények. - Veszprém megyei Múz. Közl. 14: 262-263.

ORBÁn S. (1979): Bericht über die erste Konferenz des Moosforscher-Arbeitsgemeinschaft in den sozialistischen Ländern. - Abstr. Bot. 5(Suppl. 3): 1-6.

Pócs T. (1979): XIII. Törzs: Mohák. Bryophyta. - In: HoRToвÁGYi T. (ed.): Növényrendszertan. ("Plant Taxonomy", college and university textbook +1 table). Tankönyvkiadó, Budapest, pp. 346-369.

Pócs T. (1979): Bryotaxonomical and chorological research in Hungary: Proceedings, Conferentia Bryologorum, 5-8. Junii 1978 in Eger. - Abstr. Bot. 5(Suppl. 3): 43-45.

Siller I. (1979): Mannia triandra (Scop.) Grolle in Hungary. - Acta Botanica 25(1-2): 139-142.

Simon T. (1979): Zönologische und ökologische Moospflanzenforschungen in Ungarn. - Abstr. Bot. 5(Suppl. 3): 33-42.

SzABó É. (1979): Csolnok mohái. - A tatai Herman Ottó Kör munkái 6: 107-108.

\section{0}

JuHÁsz M. (1980): Bryophyte spores from Hungarian Early Cretaceous rocks. - Acta Biol. Szeged., Nova series 26(1-4): 51-62.

Meinunger L. (1980): Adatok Magyarország flórájához. - Bot. Közlem. 67(3): 183-184.

Orbán S. (1980): Bryophyta-Mohák. - In: Soó R. (ed.): A magyar flóra és vegetáció rendszertaninövényföldrajzi kézikönyve. Akadémiai Kiadó, Budapest, pp. 20-36.

Orbán S. (1980): Adatok a Bükki Nemzeti Park (BNP) mohaflórájának ismeretéhez. - Folia Hist.nat. Mus. Matr. 6: 71-72. 
RAJCZY M. (1980): A new measure for comparing the shape of moss leaves. - Studia bot. hung. 14: 63-71.

VAJDA L. (1980): A Marsupella hungarica Boros et Vajda leírásának érvényessé tétele. (Die Geltendmachung der Beschreibung von Marsupella hungarica). - Bot. Közlem. 67(1): 35-36.

\section{1}

BAKALÁRNÉ SÜTŐ I. (1981): A Sphagnum fimbriatum a Siroki Nyírjes-tó átmeneti lápján.(Sphagnum fimbriatum in the marshy vegetation of Lake Nyirjes at Sirok). - Folia Hist.-nat. Mus. Matr. 7: 161-162.

FEHÉR G. \& ORBÁN S. (1981): A bükki „Öserdő” korhadó fáinak mohacönológiai vizsgálata. (Mosscenoses living on rotting woods of the so-called "Öserdo"” in the Bükk Mountains). - Folia Hist.-nat. Mus. Matr. 7: 15-28.

Galambos I. (1981): A Barcsi borókás tájvédelmi körzet mohaflórája. - Dunántúli Dolg. Term. Tud. Sorozat 2: 25-42.

HajDú L. \& ORBÁN S. (1981): Über die grüne Pflanzenwelt der Baradla-Höhle bei Aggtelek. Studia bot. hung. 15: 5-17.

RajCZy M. \& HolcZer Zs. (1981): Moos-arealgeographische Studien aus dem Gebiet der Karpaten und im Karpatenbecken VI. - Studia bot. hung. 15: 93-95.

VAJDA L. (1981): Erneute Validation der Beschreibung von Marsupella hungarica Boros et Vajda. - Studia bot. hung. 15: 91-92.

VAJDA L. (1981): Neue Daten zu der Moosflora des Bükkgebirges. - Studia bot. hung. 15: 92-93.

\section{2}

GALLÉ L. (1982): A Funaria hungarica Boros újabb előfordulásai a Kárpát-medencében. (New data of the Bryales species Funaria hungarica Boros in the Carpatian Basin). - Abstr. Bot. 7: 11-14.

MARSTALler R. (1982): Über einige thermophile und lichtliebende Moosgesellschaften auf Andesitgestein im Szentendre-Visegráder Gebirge (Ungarn). - Herzogia 6: 29-50.

ORBÁN S. (1982): The bryoflora of the Hortobágy National Park and the adjoining conservation areas. - In: Szuj Kó-LaCzA, J. (ed.): The flora of the Hortobágy National Park. Akadémiai Kiadó, Budapest, pp. 97-103.

ORBÁN S. (1982): Floristical and chorological investigations on bryophytes in Hungary. - Lejeunea 107: 30-31.

Suba J., KisZely-VÁmosi A., LÉGRÁdi Gy. \& OrbÁN S. (1982): Examination of the photosynthetic fixation ${ }^{14} \mathrm{CO}_{2}$ on bryophyte and lichen species. - Acta Bot. Acad. Sci. Hung. 28(1-2): 181-191.

SzerÉNYi G. (1982): A pilisi Hosszú-hegy talajlakó moháinak ökológiai vizsgálata. - Abstr. Bot. 7: $15-43$.

\section{3}

BAKALÁrné SÜtő I., Orbán S., SUba J. \& TAKÁcs B. (1983): A Cypripedium calceolus L. feltárt termőhelyei a Bükk-hegységben és környékén. (Sites of Cypripedium calceolus L. in the Bükk Mountains and its surroundings). - Folia Hist.-nat. Mus. Matr. 8: 77-84.

BALOGH M. (1983): A Velencei-tó nyugati medencéjének úszólápjai és hatásuk a vízminőségre. - Kandidátusi Értekezés, MTA, Budapest, 110 pp.

ORBÁN S. (1983): A magyarországi mohák stratégiái, összefüggésük a környezet ökológiai és cönológiai jellemzőivel. - MTA, Budapest, 115 pp. 
ORBÁN S. \& VAJDA L. (1983): Magyarország mohaflórájának kézikönyve. - Akadémiai Kiadó, Budapest, $580 \mathrm{pp}$.

RAJCZY M. (1983): About the length of active life of some xerophytic cryptogams in the dry season. - Studia bot. hung. 16: 67-72.

Vöröss L.Zs. (1983): A Pécsi Tanárképző Főiskola herbáriuma 1979-ben. - Bot. Közlem. 70 (1-2): 105-112.

\section{4}

Barbalics I. J. (1984): Magyarország új flóraeleme a Sphagnum rubellum Wils. - Vasi Szemle 38(3): 458-459.

ORbán S. (1984): A magyarországi mohák stratégiái és T, W, R értékei. - Acta Acad. Paed. Agr., Sect. Biol. 17: 755-765.

Orbán S. \& Galambos I. (1984): Crossidium crassinerve (De Not.) Jur. new member of the Hungarian bryoflora. - Bryol. Beiträge 3: 23-27.

Тива Z. (1984): Changes in photosynthetic pigment system of the drought tolerant Tortula ruralis during a daily desiccation. - In: VÁŇA J. (ed.): Proceedings of the Third meeting of bryologists from Central and East Europe. Univerzita Karlova, Praha, pp. 343-352.

\section{5}

Bíró Gy. \& Debreczy Zs.: Habitat and plant community conditions of a heliophyte, droughtand warm resistant (photofil-xerothermotolerant) moss micro-community ("Grimaldio-tortelletum" Prov.) and microrespirometric tests of its species. - Abstr. Bot. 9(Suppl. 1): 9.

Czenthe B. (1985): A keleméri Mohos-tavak cönológiai viszonyai. (Coenological relations of the "Mohos-tavak" at Kelemér). - Bot. Közlem. 72(1-2): 89-112.

DüLL R. (1985): Zygodon in Europe and Macaronesia, with special regard to Central Europe. Abstr. Bot. 9(Suppl. 2): 45-54.

Galambos I. \& Juhász M. (1985): Újabb adatok a Barcsi Borókás Tájvédelmi Körzet mohaflórájához. - Dunántúli Dolg. Term. Tud. Sorozat 5: 233.

H. Kovács K. (1985): A magyarországi barlangok mohaflórája. - Természettudományi Múzeum, Budapest, Szakdolgozat, $52 \mathrm{pp}$.

KANDA H. (1985): IAB Conference of Bryoecology, Hungary. (In Japanese.) - Proc. bryol. Soc. Japan 4: 44-46.

ORBÁn S. (1985): Preface. - Abstr. Bot. 9(Suppl. 2): 5-6.

Orbán S. (1985): Bryophyta-Mohák. - In: Priszter Sz. (ed.): A magyar flóra és vegetáció rendszertani és növényföldrajzi kézikönyve VII. Akadémiai Kiadó, Budapest, pp. 29-31.

Orbán S. (1985): A Sár-hegy mohaflórája. - Folia Hist.-nat. Mus. Matr. 10(Suppl. 1): 39-46.

ORBÁN S. (1985): The use of bryophytes for ecological comparison of vegetational units and of habitats. - Abstr. bot.9(Suppl. 1): 29.

P.-KomÁromy Zs., PADisÁ J. \& RAJCZY M. (1985): Flora in the lamp-lit areas of the cave „Annabarlang" near Lillafüred (Hungary). - Ann. hist.-nat. Mus. Nat. Hung. 77: 103-112.

PAdisÁk J., RAJCZY M., P. KomÁRomy Zs. \& HAzslinszKy T. (1985): Experiments on algae and mosses developing around different lamps in the cave "Pál-völgyi-barlang" - In: HAZSLINSZKY T. (ed.): International colloquium on lamp flora. Hungarian Speleological Society, Budapest, pp. 83-102.

PÁt KaI T., Pócs T. \& KIs G. (1985): SEM-EDX studies on mosses from polluted environments. - In: Roland Eötvös Physical Society (ed.): Hungarian-Austrian joint conference on electron mi- 
croscopy held together with XIIIth Hungarian national conference on electron microscopy: 25-27 April, 1985, Balatonaliga: Program and abstracts. ELFT, Budapest, p. 111.

RAJCZy M., PAdisáx J. \& P.-Komáromy Zs. (1985): Flora in the lamp-areas of the caves near Lillafüred (Miskolc, Hungary). - In: HAzslinszKy T. (ed.): International colloquium on lamp flora. Hungarian Speleological Society, Budapest, pp. 27-41.

RAJCzy M.: Bryophyte flora in the lamp-lit areas of the caves near Lillafüred (NE-Hungary). Abstr. Bot. 9(Suppl. 1): 33.

Simon T. (1985): The leaf-area index of three moss species. - Abstr. Bot. 9(Suppl. 1): 46.

Simon T. \& SZERÉNYi G. (1985): A study of soil characteristics under moss tufts in the acid sand area of Somogy county, Hungary. - Abstr. Bot. 9(Suppl. 2): 205-218.

TuвA Z. (1985): Light, temperature and desiccation responses of $\mathrm{CO}_{2}$-exchange in Tortula ruralis. - Abstr. Bot. 9(Suppl. 1): 50.

TuвA Z. (1985): Photosynthetic pigment responses in Tortula ruralis during daily desiccation. Abstr. Bot. 9(Suppl. 2): 231-239.

VÉGH Zs. (1985): Lamp flora in the Aggtelek cave. - In: Hazslinszky T. (ed.): International Colloquium on lamp flora. Hungarian Speleological Society, Budapest, pp. 51-60.

Vöröss L. Zs. (1985): Mnium hornum és Lycopodium clavatum a Tarnavidéken, Domaházán. Bot. Közlem. 72(1-2): 181-183.

\section{6}

Galambos I. (1986): Contributions to the Hungarian bryoflora. - Studia bot. hung. 19: 89-91.

GRADSTEIN S. R. (1986): The bryoecology conference in Hungary, 1985. - Taxon 35(3): 614-615.

MARSTAller R. (1986): Zur räumlichen Anordnung einiger Moosgesellschaften im Bereich xerothermer Waldstandorte am Beispiel der Fehér kövek bei Sümeg (Komitat Veszprém) in Ungarn. - Gledischia 14: 343-348.

Olasz T. (1986): A Dicranella cerviculata (Hedw.) Schimp. újabb magyarországi előfordulása. (A new record of Dicranella cerviculata (Hedw.) Schimp. in Hungary). - Bot. Közlem. 73(1-2): 77-79.

RajCzy M., Buczkó K. \& P. Komáromy Zs. (1986): Contributions to the flora of the Hungarian caves I. Flora of the entrances of the caves Lök-völgyi-barlang and Szeleta-barlang. - Studia bot. hung. 19: 79-88.

Tótн Z. (1986): A Tortula Hedw. Sect. Rurales De Not. (Musci, Pottiaceae) rendszertani revíziója és elterjedése a Kárpát-Medencében (Taxonomic revision of Tortula Hedw. sect. Rurales De Not. (Musci, Pottiaceae) and its distribution in the Carpathian Basin). - Abstr. Bot. 10: 145-185.

TuвA Z. (1986): A mohák bioindikátor szerepe. (Bioindicator role of bryophytes). - In: Kovács M., PoDANi J., TubA Z. \& TurcsáNyi G. (eds): A környezetszennyezést jelző és mérő élőlények. (Bioindication of environmental pollution). Mezőgazdasági Kiadó, Budapest, pp. 76-82.

\section{7}

BAKalárné Sü Tő I., Kiszely-VÁmosi A., Orbán S., Suba J. \& TAKÁcs B. (1987): Az Esztramoshegy bányászattól érintetlen gerincének florisztikai viszonyai. (The conditions of the flora on the ridge of Estramos Hill unaffected by mining activities). - Acta Acad. Paed. Agr. Nova Series, Sect. Biol. 18(2): 35-50.

BALÓ K. (1987): Some photosynthesis-ecological characteristics of forest bryophytes. - Symposia Biol. Hung. 35 Part A: 125-136. 
Bíró Gy. \& Debreczy Zs. (1987): Ecological conditions in a photophilous-xerothermotolerant moss community (Mannio-/Grimaldio-) tortelletum inclinatae (Assoc. nov.) and microrespirometric tests of its species. - Symposia Biol. Hung. 35 Part A: 81-102.

KIss T. (1987): Regressive succession induced by acid rain in cryptogamic communities inhabiting Juglans bark. - Symposia Biol. Hung. 35 Part A: 865-882.

MÁzsa K., KovÁcs-LÁNG E. \& SNAKIN V. V. (1987): Changes in soil pH along the zonation of cryptogamous synusia at Bugac (Hungary). - Symposia Biol. Hung. 35 Part A: 33-37.

OrBÁN S. (1987): László Vajda 1890-1986. (obituary). - The Bryological Times 41: 6.

ORBÁN S. (1987): The use of bryophytes for ecological comparison of vegetational units and of habitats. - Symposia Biol. Hung. 35 Part A: 379-404.

RajCzy M. (1987): In memoriam László Vajda (1890-1986). - Ann. Hist.-nat. Mus. Nat. Hung. 79: $37-42$.

Simon E. (1987): Liophyllum palustre, a parasite on Sphagnum. - Symposia Biol. Hung. 35 Part A: $165-174$.

Simon T. (1987): The leaf area index of three moss species (Tortula ruralis, Ceratodon purpureus and Hypnum cupressiforme). - Symposia Biol. Hung. 35 Part B: 699-706.

Tótн Z. (1987): A phytogeographic review of Tortula Hedw. sect. Rurales De Not. (Pottiaceae, Musci) in Hungary. - Acta Bot. Hung. 33(3-4): 249-278.

TuвA Z. (1987): Method for the determination of the entire photosynthetic pigment composition of bryophytes. - In: RUdolph H. \& Hartmann E. (eds): Bryological Methods Workshop. (Developments, enviroment, metabolism, systematics). Johannes Gutenberg University Press, Mainz, pp. 118-119.

TuвA Z. (1987): Light, temperature and desiccation responses of $\mathrm{CO}_{2}$-exchange in desiccation tolerant moss, Tortula ruralis. - Symposia Biol. Hung. 35 Part A: 137-150.

Zólyomi B. (1987): Buntflechtenmoos und lebermoos synuzien. - Symposia Biol. Hung. 35 Part A: $375-378$.

\section{8}

Daróczy S., Bolyós A., Dezső Z., Pázsit Á., Nagy J. \& Nagy M. (1988): Could mosses be used for the subsequent mapping of the Chernobyl fallout? - Naturwissenschaften 75(11): 569-570.

Galambos I. (1988): Vajda László 1890-1986. - Fol. Mus. Hist.-nat. Bakonyiensis 7: 7-10.

ORBÁN S. (1988): Mohák stratégiáinak ökológiai, cönológiai összefüggései. - In: BARTHA S. (ed.): I. Magyar Ökológus Kongresszus, Budapest, Összefoglalók, p. 139.

Smith A. J. E. (1988): Proceedings of the IAB Conference on Bryoecology, Vols A \& B. by T. Pócs, T. Simon, Z. Tuba, J. Podani - J. Ecol. 76(2): 602-603. https://doi.org/10.2307/2260618

TAN B. C. (1988): Proceedings of the IAB Conference of Bryoecology by T. Pócs, T. Simon, Z. Tuba, J. Podani. - The Bryologist 91(2): 158-159. https://doi.org/10.2307/3242636

\section{9}

Buczkó K. \& RAjCzy M. (1989): Contribution to the flora of the Hungarian caves II. Flora of three caves near Beremend, Hungary. - Studia bot. hung. 21: 13-26.

Kiszely-Vámosi A., Marschall Z., Suba J. \& Orbán S. (1989): A Bükk hegység északi peremhegyeinek florisztikai és cönológiai jellemzése. - Acta Acad. Paed. Agr., Sect. Biol. 19(6): $135-185$. 
ORBÁN S. (1989): The coenological and ecological connections of the life strategies of bryophytes. In: Herben T. \& McQueen C. B. (eds): Proceedings of the sixth meeting of the Central and East European Bryological Working Group (CEEBWG): Liblice, Czechoslovakia, 12th through 16th September, 1988. Botanical Institute of the Czechoslovak Academy of Sciences, Průhonice, pp. 172-179.

Orbán S. (1989): Analysis of some plant communities based on bryophyte layer. - Acta Acad. Paed. Agr., Sect. Biol. 19(6): 197-209.

RAJCZY M. (1989): The flora of Hungarian caves. - Karszt és Barlang 1989 (Special Issue): 69-72. Standovár T. \& Tóth Z. (1989): Vegetation map of the Bátorliget Mire Preserve, 1989. - Abstr. Bot. 13: 153-157.

Voj т Kó A. (1989): A Felső-Szoros mohaflórája. - Acta Acad. Paed. Agr.: Nova series 19(6): 231-235.

Wiehle W. (1989): Pócs T., Simon T., Tuba Z. \& Podani J. (eds), Proceedings of the IAB Conference of Bryoecology. Budapest - Vácrátót, Hungary, 5-10 August, 1985. Part A + Part B. (Symposia Biologica Hungarica; 35). Akadémiai Kiadó, Budapest 1987. - Feddes Repertorium 100(7-8): 356.

\section{0}

ORBÁN S. (1990): Life strategies of endangered bryophytes in Hungary. - Biol. Conservation 59: 109-112. https://doi.org/10.1016/0006-3207(92)90568-8

Purger Z. (1990): Mohaismertetô., - Erdészeti és Faipari Egyetem Erdőmérnöki Kar, Sopron.

RajCZY M. (1990): Mohák. Bryophyta. - In: RakonCZAY Z. (ed.): Vörös Könyv. Akadémiai Kiadó, Budapest, pp. 322-325.

STANdovár T. \& Tóth Z. (1990): Bátorliget botanikai felmérése. - In: Zalainé Kovács É. (ed.): Lippay János Tudományos Ülésszak előadásainak és posztereinek rövid összefoglalói (1990. november 7-8.), Kertészeti Szekció. Kertészeti és Élelmiszeripari Egyetem kiadványai, Budapest, p. 348.

Tuba Z., Csintalan Zs. \& Meenks J. L. D. (1990): Introduction of measuring remoistening $\mathrm{CO}_{2}$-exchange in lichens and bryophytes for indicating air pollution. - Physiol. Plantarum 79(2): A125.

\section{1}

Dulai S. \& VojTKó A. (1991): Az egerbaktai tőzegmohás láp állapotfelmérése összefüggésben az ökológiai adottságokkal. - Folia Hist.-nat. Mus. Matr. 16: 45-70.

JEANPLONG J. (1991): A kemeneskápolnai láp a múlté. - Vasi Szemle 45(2): 274-276.

KÁRÁsz I. (1991): A verpeléti Várhegy flórája és természetvédelmi értékelése. - Acta Acad. Paed. Agr., Nova series 20: 117-131.

KóNYA E. (1991): A mohaboritás mérése és összehasonlitása különbözö növénytársulásokban. - In: PEREG Ovits L. (ed.): II. Magyar Ökológus Kongresszus: 1991. július 4-7., PATE, Georgikon, Keszthely: Poszterek összefoglalói PATE, Keszthely, p. 82.

MARSChALL M. (1991): Moha és talaj kölcsönhatások erdö- és gyeptársulásokban. OTDK dolgozat, KLTE, TTK, Debrecen, 45 pp.

Meenks J. L. D., Tuba Z. \& Csintalan Zs. (1991): Ecophysiological responses of Tortula ruralis upon transplanation around a power plant in west Hungary. - J. Hattori Bot. Lab. 69: 21-35.

ORBÁN S. (1991): A mohakutatás alakulása hazánkban az utóbbi évtizedekben. (Decades in the Hungarian bryology). - Bot. Közlem. 78(Suppl.): 29-32. 
ORBÁN S. (1991): The dynamics of the bryophyte layer of disturbed communities on the basis of life strategy examinations. - In: Abstracts of the Lectures \& Posters: 34th IAVS Symposium, 2630, August 1991 Eger, Hungary, p. 92.

ORbÁn S. (1991): Mohák. - In: Simon T. (ed.): Baktérium-, alga-, gomba-, zuzmó- és mohahatározó. Tankönyvkiadó, Budapest, pp. 677-778.

Orbán S., Marschall Z., Kónya E., LÉGrády Gy., Suba J., Kárász I., Tuba Z., Varga J. \& DósA G. (1991): A mohák életstratégiái, vizsgálatának eredményei. - In: Peregovits L. (ed.): II. Magyar Ökológus Kongresszus: 1991. július 4-7., PATE, Georgikon, Keszthely: Poszterek összefoglalói. PATE, Keszthely, p. 110.

Orbán S., MARSChall M. \& MÉszáros I. (1991): Moha és talaj kölcsönhatások erdö- és gyeptársulásokban. - In: Peregovits L. (ed.): II. Magyar Ökológus Kongresszus: 1991. július 4-7., PATE, Georgikon, Keszthely: Poszterek összefoglalói. PATE, Keszthely, p. 93.

Orbán S., MARSChall Z., SUba J. \& VojtKó A. (1991): Vegetációtanulmányok a Bükk hegységben: a Messzelátó-hegy, Ördög-hegy növényzete. - Acta Acad. Paed. Agr., Nov. ser. 20: 139-159.

PURGer Z. (1991): A mohagyep szerepe az erdők természetes újulatának megtelepedésében. (On the role of mosses in the natural regrown of forests). - Természetvédelmi Közlem. 1: 13-18.

Standovár T., Tóth Z. \& Simon T. (1991): Vegetation of the Bátorliget mire Reserve. - In: MAHUNKA S. (ed.): Bátorliget Nature Reserves - after forty years. Hungarian Natural History Museum, Budapest, pp. 57-118.

Suba J., MARsChall M. \& WitTchen T. (1991): Mohafajok fotoszintézis-ökológiai vizsgálata. In: Pereg ovits L. (ed.): II. Magyar Ökológus Kongresszus: 1991. július 4-7., PATE, Georgikon, Keszthely: Poszterek összefoglalói. PATE, Keszthely, p. 135.

VArga J. (1991): Adatok Felsőtárkány területének bryofaunájára vonatkozóan. - Acta Acad. Paed. Agr., Nova series 20: 81-88.

\section{2}

Galambos I. (1992): A Zirci Arborétum mohaflórája. (Musci of the arboretum of Zirc). - Fol. Mus. Hist.-nat. Bakonyiensis 11: 29-35.

Galambos I. (1992): A Barbula s. l. nemzetség magyarországi fajainak revíziója. (A revision of Hungarian Barbula s. 1. (Musci: Bryophyta, Pottiaceae) species). - Fol. Mus. Hist.-nat. Bakonyiensis 11: 37-144.

MARSChall M. (1992): Mohák elemtartalmának és termőhelyindikációjának összefüggései. - In: Díjnyertes dolgozatok kiadványa, OKTDK dolgozat, Szeged, pp. 103-110.

Meenks J. L. D., Csintalan Zs. \& TUba Z. (1992): Ecophysiological responses of Tortula ruralis upon lead and cadmium treatments. - In: MÉszÁros I., GebefüGI I. \& LöRINCI I. (eds): Proceedings of Symposium on ecological approaches of environmental chemicals. GSF Bericht 4/92: 31-44.

MeEnKs J. L. D. \& TubA Z. (1992): Bryophytes as biological indicators. - In: KovÁcs M. (ed.): Biological indicators in environmental protection. Ellis Horwood Ltd. Publ. \& Akadémiai Kiadó, Chichester \& Budapest, pp. 65-75.

ORBÁN S. (1992): Life strategies in endangered bryophytes in Hungary. - Biological Conservation 59(2-3): 109-111. https://doi.org/10.1016/0006-3207(92)90568-8

PAPP B. (1992): A Koloska-völgy patakmenti növényzetének állapotfelmérése és térképezése.(Mapping and survey on the condition of vegetation along the Koloska karst stream in Hungary). - Bot. Közlem. 79(1): 1-17.

Simon T. (1992): Vegetation change and protection of the Csaroda relic mires, Hungary. - Acta Soc. Bot. Pol. 61 (1): 63-74. https://doi.org/10.5586/asbp.1992.005 
Tóтн Z. (1992): Bátorliget mohaflórájának elemzése. (Analysis of the bryophyte flora of the Bátorliget Mire Reserve). - In: Vort P. (ed.): Lippay János Tudományos Ülésszak előadásai (1992. november 4-5.). Kertészeti és Élelmiszeripari Egyetem kiadványai, Budapest, pp. 212-215.

Tuba Z. \& Csintalan Zs. (1992): Introduction of cryptogamic ecophysiological monitoring system in Hungary for indication of air pollution and other environmental effects. - In: SCHLEICHER K. (ed.): Pollution knows no frontiers: priorities for Pan European Cooperation. Paragon House, New York, pp. 199-211.

\section{3}

Boros Á., Járai-Komlódi M., Tóth Z. \& Nilsson S. (1993): An atlas of recent European bryophyte spores. - Scientia Publishing, Budapest, 321 pp.

Dobolyi K. Z., Szerdahelyi T. \& Szollát Gy. (1993): Botanical bibliography of the Pilis Nature Preservation Area (Hungary). - Studia bot. hung. 24: 77-90.

Gólya I. \& SEbESTYÉN R. (1993): Mohák cézium-szennyezettsége Vas megyében. - Izotóptechnika, diagnosztika 36(3-4): 163-165.

Marschall M. \& MÉszáros I. (1993): Some ecophysiological features in a desiccation tolerant moss species (Tortula ruralis) under drought stress. - In: 8th CEEBWG Meeting, Eger, Magyarország, p. 14.

Marstaller R. (1993): Die Moosgesellschaften des Villányer Gebirges in Südungarn. - Phytocoenologia 22(2): 193-273. https://doi.org/10.1127/phyto/22/1993/193

Tuba Z. \& Csintalan Zs. (1993): The use of moss cushion transplantation technique for bioindication of heavy metal pollution. - In: MARKERT B. (ed.): Plants as biomonitors for heavy metal pollution of terrestrial environments. VCH Publisher, Inc. Weinheim, New York, pp. 403-412.

Voj Tó A. (1993): The spore morphology of Hepaticae species. - Acta Biol. Szeged. 39: 59-69.

\section{4}

Csintalan Zs., TAKÁcs Z. \& TuBA Z. (1994): Közúti forgalom okozta környezetszennyezés hatásának kriptogám ökofiziológiai bioindikációja. - In: Peregovits L. \& Löкös L. (eds): III. Magyar Ökológus Kongresszus: Előadás-kivonatok és poszter-összefoglalók. Szeged, p. 25.

Csintalan Zs., Tuba Z. \& Meenks J. L. D. (1994): Kadmium- és ólomkezelt Tortula ruralis ökofiziológiai válaszai. (Ecophysiological responses of Tortula ruralis upon treatments with lead and cadmium). - Bot. Közlem. 80(2): 205-215.

Daróczy S., Bolyós A., Dezső Z., Pázsit Á., Nagy J., Tamási T., Benke E. \& Nagy M. (1994): Subsequent mapping of 137 Cs fallout from Chernobyl in Hungary using the radioactivity found in mosses. - Naturwissenschaften 81(4): 175-177.

Galambos I. (1994): Boros Ádám és a szervezett Bakony-kutatás (1962-1972). - Studia bot. hung. 25: 97-99.

Gólya I. \& SEBESTYÉn R. (1994): Mohák radioaktivitása Vas megyében. - Bot. Közlem. 81(2): 201-207.

Kámory E., Keserü Gy. M. \& PAPp B. (1994): A gyógyító moha. - Természettudományi Közlöny 525: 564 .

MARSCHALL M. \& MÉSZÁRos I. (1994): Ökofiziológiai jellemzök vizsgálata egy kiszáradástoleráns mohafaj, a Tortula ruralis desszikációja során. - In: Peregovits L. \& Löкös L. (eds): III. Magyar Ökológus Kongresszus: Előadás-kivonatok és poszter-összefoglalók. Szeged, p. 109.

MARSCHALl M. \& MÉszÁros I. (1994): Some data to the applicability of bryophytes as bioindicators. - Acta Biologica Debrecina-Supplementum Oecologica Hungarica 5: 245-255. 
Marschall M., MészÁros I. \& Somogyi A. (1994): Adatok mohafajok bioindikátor szervezetként való alkalmazhatóságához. - In: Peregovits L. \& Lökös L. (eds): III. Magyar Ökológus Kongresszus: Előadás-kivonatok és poszter-összefoglalók. Szeged, p. 110.

Marschall Z., Cseh R., Dulai S. \& Molnár I. (1994): Xero- és mezofil mohafajok fotoszintézisökológiai tulajdonságainak szezonális dinamikája. - In: Peregovits L. \& Lökös L. (eds): III. Magyar Ökológus Kongresszus: Előadás-kivonatok és poszter-összefoglalók. Szeged, p. 111.

MARSTALlER R. (1994): Zur Verbreitung bemerkenswerter Moose in der Umgebung von Budapest (Ungarn). - Feddes Repert. 105: 531-547. https://doi.org/10.1002/fedr.19941050718

Orbán S. (1994): A magyarországi mohászat rövid története. - Studia bot. hung. 25: 101-102.

Penksza K., Turcsányi G. \& Kovács M. (1994): A Siroki Nyírjestó tőzegmohalápjának elemkatasztere. (Element concentration cadasters of a peat profiles in Nyírjes bog near Sirok in Hungary). - Bot. Közlem. 81(1): 29-41.

Pócs T. (1994): Boros Ádám, a bryológus. - Studia bot. bung. 25: 91-93.

Purger Z. (1994): A Köszegi-hegység mohaflórája. - In: BArTha D. (ed.): A Kőszegi-hegység vegetációja I-II. EFE Növénytani Tanszék, Kőszeg-Sopron, pp. 33-41.

RAJCZY M. (1994): Boros Ádám herbáriuma. - Studia bot. hung. 25: 99-100.

Simon T. (1994): Boros Ádám, a flórakutató. - Studia bot. hung. 25: 94-95.

Tuba Z., Csintalan Zs., NAgy Z., Szente K. \& TAKÁcs Z. (1994): Sampling ofterricolous lichen and moss species for trace element analysis, with special reference to bioindication of air pollution. - In: MARKERT B. (ed.): Environmental sampling for trace analysis. VCH, Weinheim, pp. 415-434.

\section{5}

Csintalan Zs., Tuba Z. \& Laitat E. (1995): Photosynthetic acclimation of the forest moss Polytrichum formosum to long-term elevated $\mathrm{CO}_{2}$. - In: MATHIs P. (ed.): Photosynthesis: from light to biosphere. Proceedings of the 10. International Photosynthesis Congress, Montpellier, France. Kluwer Acad. Publ., Dordrecht, pp. 925-928.

Csintalan Zs., Tuba Z. \& LAitat E. (1995): Slow chlorophyll fluorescence, net $\mathrm{CO}_{2}$ assimilation and carbohydrate responses in the forest moss Polytrichum formosum to elevated $\mathrm{CO}_{2}$ concentrations. - In: Mathis P. (ed.): Photosynthesis: from light to biosphere. Proceedings of the 10. International Photosynthesis Congress, Montpellier, France. Kluwer Acad. Publ., Dordrecht, p. 925. https://doi.org/10.1007/978-94-009-0173-5_1129

ECCB (1995): Red data book of European bryophytes. - European Committee for Conservation of Bryophytes. Trondheim, $291 \mathrm{pp}$.

JAKAв G. \& Lesku B. (1995): Piricse-Júlia-liget: egy ismeretlen láp Bátorliget árnyékában. - Calandrella 9: 9-21.

KÁMORY E., KeSERÜ Gy. M. \& PAPP B. (1995): Isolation and antibacterial activity of marchantin A, a cyclic bis(bibenzyl) constituent of Hungarian Marchantia polymorpha L. - Planta Medica 61: 387-388.

KRöel-Dulay Gy. (1995): A magyarországi tözegmohalápok összehasonlító vizsgálata. - manuscript (MSc theses), ELTE Növényrendszertani és Ökológiai Tanszék, Budapest.

MARSChAll M., Dulai S. \& MolnáR I. (1995): The applicability of chlorophyll fluorescence as a sensitive indicator of desiccation in a liverwort, Porella platyphylla. - In: MATHIS P. (ed.): Photosynthesis: from light to biosphere. Proceedings of the 10. International Photosynthesis Congress, Montpellier, France. Kluwer Acad. Publ., Dordrecht, pp. 517-520. https://doi.org/10.1007/978-94-009-0173-5_818

MarSChall M., Dulai S. \& Molnár I. (1995): The applicability of chlorophyll fluorescence as a sensitive indicator of desiccation in a liverwort, Porella platyphylla. - Photosynthesis Research 1: 200 . 
Marschall Z. \& Gyarmati A. (1995): A Plagiochila asplenioides előfordulása a Keserü-völgyben (Heves-Borsodi dombság). - Acta Acad. Agr., Nova Series 21 (Suppl. 1): 397-401.

MARSTALler R. (1995): Die azidophytische Bryophytenvegetation in einigen Gebirgen in der Umgebung von Budapest (Ungarn). - Feddes Repert. 106: 247-270.

https://doi.org/10.1002/fedr.19951060320

Marstaller R. (1995): Die Bryophytenvegetation einiger Gebirge in der Umgebung von Budapest (Ungarn) Teil 1: Die Moosgesellschaften der Verbände Grimmion tergestinae SM. 1947 und Grimaldion fragrantis Had. et. Sm 1944. - Beitr. Ökol. 1: 121-168.

ORBÁN S. (1995): Mohák szerepe az erdei társulásokban, társulások értékelése mohaflórájuk alapján. - Tilia 1: 185-198.

Orbán S. \& Tóth Z. (1995): Mohák. - In: Járai-Komlódi M. (ed.): A magyar flóra. Pannon Enciklopédia, Magyarország növényvilága. - Dunakanyar 2000 Kiadó, Budapest, pp. 100-109.

PAPP B. \& RAJCZY M. (1995): Changes of bryophyte vegetation and habitat conditions along a section of the river Danube in Hungary. - Cryptog. Helv. 18: 95-106.

TuвA Z. \& Kis G. (1995): Ritka mohafajok a magyarországi Bodrogközben. (Rare bryophyte species in the Hungarian Bodrogköz). - Bot. Közlem. 82(1-2): 55-57.

Tuвa Z. (1995): Overview of the flora and vegetation of the Hungarian Bodrogköz. - Tiscia 29: $11-17$

Vojt Kó A. \& MARschall Z. (1995): Botanikai vizsgálatok a Komlóska patak (Zempléni-hegység) láprét együttesén. (Botanical researches on the fens of Komlóska stream (Zemplén Mts).) - Acta Acad. Agr., Nova Series 21 (Suppl. 1): 371-378.

\section{6}

Erzberger P. (1996): Zur Verbreitung von Hedwigia stellata in Europa. - Herzogia 12: 221-238.

Gyarmati A. \& Marschall Z. (1996): Bryoflora of Aggtelek National Park. - In: Barati S. (ed.): Research, conservation, management; Symposium Abstract Volume. Aggtelek-Jósvafö, p. 120.

ITTzÉs P. (1996): Adatok az Északi-középhegység mohaflórájához. (Some floristic data on the bryophyte-flora of Northern Mountains of Hungary). - Kitaibelia 1(1): 34-35.

JAKAB G. \& LESKU B. (1996): Egy újabb ősláp a Nyírségben: A piricsei Júlia-liget botanikai értékei I. - Kitaibelia 1(1): 46-55.

MARSTALler R. (1996): Die Bryophytengesellschaften der Ordnungen Neckeretalia complanatae Jez. et Vondr. 1962 und Leptodictyetalia riparii Phil. 1956 in einigen Gebirgen bei Budapest (Ungarn). - Nova Hedwigia 63: 229-260.

Marstaller R. (1996): Die Bryophytengesellschaften des Verbandes Ctenidion mollusci Stef. 1941 in der Umgebung von Budapest (Ungarn). - Tuexenia 16: 553-578.

MARSTALLER R. (1996): Epiphytische Moosgesellschaften in der westlichen Baranya (Ungarn). Tuexenia 13: 519-531.

ÓDOR P. (1996): Coenological study of club moss populations in the west part of Hungary. - Abstr. Bot. 20(1): 47-52.

Ódor P., SzURDoki E. \& Tóth Z. (1996): Újabb adatok a Vendvidék mohaflórájához. (Recent data for the bryoflora of Vendvidék (Hungary)). - Bot. Közlem. 83(1-2): 97-108.

PAPp B. \& RajCzy M. (1996): Az Örség mohaflórája a Magyar Természettudományi Múzeum Növénytára mohaherbáriuma alapján. (Hepatics and mosses of Örség (Western Hungary) on the basis of the Herbarium Bryophytorum of the Hungarian Natural History Museum). Savaria, a Vas Megyei Múzeumok Értesitóje 23(2): 275-295.

PAPP B. \& RAJCZY M. (1996): Bioindication of habitat conditions with bryophytes at some streams in Aggtelek National Park and Balaton-felvidék region, Hungary. - In: BARATI S. (ed.): Research, conservation, management; Symposium Abstract Volume. Aggtelek-Jósvafö, p. 127. 
PAPP B. \& RAJCZY M. (1996): Changes of aquatic and riparian bryophyte vegetation in Szigetköz. In: BercziK Á. (ed.): 31. Konferenz der IAD, Baja Ungarn 1996, Limnologische Berichte. Donau 1996, I. Wissenschaftliche Referate. MTA ÖBKI Magyar Dunakutató Állomás, Vácrátót/Göd, pp. 157-162.

SÜMEGi P. (1996): A bátorligeti láp fejlödéstörténete. - Calandrella 10:151-160.

SzURDOKI E. (1996): Distribution and coenological preferance of Sphagnum species in the Vendvidék. - In: Barati S. (ed.): Research, conservation, management; Symposium Abstract Volume, Aggtelek-Jósvafö, p. 105.

Tuba Z., Csintalan Zs. \& Proctor M. C. F. (1996): Photosynthetic responses of a moss, Tortula ruralis (Hedw.) Gaertn. et al. ssp. ruralis, and the lichens Cladonia convoluta (Lam.) P. Cout. and C. furcata (Huds.) Schrad. to water deficit and short periods of desiccation, and their eco-physiological significance: a baseline study at present-day $\mathrm{CO}_{2}$ concentration. - New Phytol. 133(2): 353-361. https://doi.org/10.1111/j.1469-8137.1996.tb01902.x

Tuba Z., Szente K., Csintalan Zs., Nagy Z., Takács Z., Koch J., Badacsonyi A., MuraKeÖZy É.P., MaSARovicova E., SMIRnOfF N. \& Proctor M.C. F. (1996): Ecophysiological acclimation of flower and cryptogamic dry grassland species to long-term elevated $\mathrm{CO}_{2}$. Plant Phys. Biochem. (special issue): 325-326.

\section{7}

BuczKó K., RajCzy M., Ács É. \& PApp B. (1997): Signals of cryptogams. - In: LÁNG I., BanCZEROWSKI I. \& BERCZIK Á. (eds): Studies on the environmental state of the Szigetköz after the diversion of the Danube. MTA Szigetköz Bizottság, Budapest, pp. 83-96.

Csintalan Zs., Takács Z., Tuba Z., Proctor M. C. F., Smirnoff N. \& Grace J. (1997): Desiccation tolerant grassland cryptogams under elevated $\mathrm{CO}_{2}$ : preliminary findings. - Abstr. Bot. 21(2): 309-315.

Gyarmati A. \& MARSCHALl Z. (1997): Results of bryological research in Aggtelek National Park in the frame of complex ecological state assessment. - In: TóTH E. \& HoRVÁTH R. (eds): Research in Aggtelek National Park and Biosphere Reserve. Proceedings of the "Research, conservation, management” Conference. Aggtelek, Hungary, 1-5 May 1996. II. Aggtelek National Park Directorate, Jósvafö, pp. 269-274.

JАКАв G. (1997): Egy újabb ősláp a Nyírségben: A piricsei Júlia-liget botanikai értékei II. (MohákBryophyta). (The flora of the "Júlia-liget" near Piricse II. (Bryophyta)). - Kitaibelia 2(1): 46-50.

JAKAB G. (1997): A Nyírség mohaflórája I. (florisztikai rész). (Bryophyte flora of Nyírség (NE Hungary) I.). - Kitaibelia 2(2): 148-159.

JАКАВ G. (1997): Egy újabb glaciális reliktum a keleméri Kis-Mohosról. - Kitaibelia 2(2): 159.

Kis G. \& Tuba Z. (1997): Mohaadatok a Bodrogközből. - Kitaibelia 2(2): 219-220.

Marstaller R. (1997): Die Moosgesellschaften der Ordnung Orthotrichetalia Had. in Kl. et Had. 1944 in der Umgebung von Budapest, Ungarn. - Tuexenia 17: 327-336.

NAGY J. (1997): Research establishing the biomonitoring of Lake Bence (Bence-tó) at the northern part of the Great Hungarian Plain. - In: Tóth E. \& HoRváth R. (eds): Research in Aggtelek National Park and Biosphere Reserve. Proceedings of the "Research, conservation, management" Conference. Aggtelek, Hungary, 1-5 May 1996. I. Aggtelek National Park Directorate, Jósvafó, pp. 153-158.

PAPP B. (1997): Balaton-felvidéki Aszóföi-séd és a Pécsely-patak mohavegetációjának vizsgálata. Hidrol. Közl. 77(1-2): 77-79.

PAPP B. \& RAJCZY M. (1997): Bioindication of habitat conditions with Bryophytes at some streams in Aggtelek National Park and Balaton-felvidék region, Hungary. - In: TóTH E. \& HoRVÁTH 
R. (eds): Research in Aggtelek National Park and Biosphere Reserve. Proceedings of the "Research, conservation, management" Conference. Aggtelek, Hungary, 1-5 May 1996. II. Aggtelek National Park Directorate, Jósvafö, pp. 47-57.

Purger Z., Balogh L., Papp B., Rajczy M. \& Szmorad F. (1997): A Kőszegi-hegység mohaflórája. - Tilia 5: 94-271.

Rogovszky Z. (1997): Állapotjelentés a Szöcei Tözegmohásról. - kutatási jelentés (kézirat), Fiatalok Természetismereti Klubja, 23 pp.

SZÖvÉNYI P. (1997): A kőszegi tőzegmohás lápok. - Tilia 5: 272-312.

SZURDOKI E. (1997): Distribution and coenological preferance of Sphagnum species in Vendvidék.

- In: Tóth E. \& Horváth R. (eds): Research in Aggtelek National Park and Biosphere

Reserve. Proceedings of the "Research, conservation, management" Conference. Aggtelek, Hungary, 1-5 May 1996. I. Aggtelek National Park Directorate, Jósvafo,, pp. 393-402.

Tóтн Z. (1997): A beregi tőzegmohás lápok. - Természet Világa 128(9): 420-422.

TuвA Z. (1997): A mohák, mint a környezet nehézfém terhelésének jelzöi és méröi. - In: BALOGH Á. (ed.): Környezeti biokémia. Studium Kiadó, Nyíregyháza, pp. 236-251.

Tuba Z., Csintalan Zs., Badacsonyi A. \& Proctor M. C. F. (1997): Chlorophyll fluorescence as an exploratory tool for ecophysiological studies on mosses and other small poikilohydric plants. - J. Bryol. 19(3): 401-407. https://doi.org/10.1179/jbr.1997.19.3.401

\section{8}

Csintalan Zs., Takács Z., Proctor M. C. F., Lichtenthaler H. K. \& Tuba Z. (1998): Dessication and rehydration responses of dessication tolerant moss and lichen species from a temperate semidesert grassland. - J. Hattori Bot. Lab. 84(1): 71-80.

ERzberger P. (1998): Tortula brevissima Schiffn. - eine für die Flora Ungarns neue Moosart. Bot. Közlem. 85(1-2): 63-72.

JAKAв G. (1998): A Nyírség mohaflórája II. (biogeográfiai rész). (Bryophyte flora of Nyírség (NE Hungary) II). - Kitaibelia 3(1): 137-149.

JAKAB G. \& LESKU B. (1998): Aktuális botanikai kutatások a Kelet-Nyírségben. - Kitaibelia 3(1): 99-101.

Jakab G., Magyari E., Rudner E. \& Sümegi P. (1998): A keleméri Nagy-Mohos tó fosszilis mohaflórája. (Fossil mosses of Nagy-Mohos bog near Kelemér (NE Hungary)). - Kitaibelia 3(2): 353-354.

LÁJER K. (1998): Az Aldrovanda vesiculosa L. újabb előfordulása és egyéb adatok Magyarország flórájának ismeretéhez. - Kitaibelia 3(2): 263-274.

LÁJER K. (1998): Bevezetés a magyarországi lápok vegetáció-ökológiájába. - Tilia 6: 84-238.

MARSCHALL M. (1998): Nitrate reductase activity during desiccation and rehydration of the desiccation tolerant moss Tortula ruralis and the leafy liverwort Porella platyphylla. - J. Bryol. 20(2): 273-285. https://doi.org/10.1179/jbr.1998.20.2.273

Marschall M., Proctor M. C. F. \& MolnÁr I. (1998): Chlorophyll-fluorescence measurements during drying and remoistening of the desiccation-tolerant leafy liverwort Porella platyphylla. - In: GARAB Gy. (ed.): Photosynthesis: mechanisms and effects Volume IV. Proceedings of the XIth international congress on photosynthesis. Budapest, Magyarország, August 17-22, 1998. Springer Science + Business Media, B. V., Dordrecht, pp. 2593-2596. https://doi.org/10.1007/978-94-011-3953-3_609

MARSChall Z., PÉli E. R. \& Cseh R. (1998): Investigation of the photosynthetical properties of Hypnum cupressiforme moss types adapted to different stress factors. - In: GARAB Gy. (ed.): Photosynthesis: mechanisms and effects Volume V. Proceedings of the XIth international 
congress on photosynthesis. Budapest, Magyarország, August 17-22, 1998. Springer Science + Business Media, B. V., Dordrecht, pp. 4085-4088.

Mázsa K., Mészáros R. \& Kalapos T. (1998): Ecophysiological background of microhabitat preference by soil-living lichens in a sand grassland-forest mosaic; study plan and initial results. (Ökophysiologische Parameter der bodenbewohnenden Flechten und Moose im Spiegel der Standortwahl der Arten: Forschungsplan und einige vorläufigen Ergebnisse). Sauteria 9: 165-171.

Melikant B. \& Bisztray Gy. (1998): Physcomitrella p. mohanövények transzformálása TetR transzgénnel. - In: ILLÉs É. (ed.): A „Lippay János - Vas Károly” Tudományos Ülésszak Elöadásainak és Posztereinek Összefoglalói. Budapest, 1998. szeptember 16-18. Kertészet. Kertészeti és Élelmiszeripari Egyetem, Budapest. pp. 36-37.

NAGY J. \& FigeczKy G. (1998): Decay of peat moss cushions on the Lake Bence-tó in the northern part of the Great Hungarian Plain. - Studia bot. bung. 27-28: 163-167.

Nagy J., Figeczky G., Penksza K., Fintha I., Molnár A., Tóth Z. \& Kalapos T. (1998): Contributions to the flora and vegetation of the Lake Bence-tó, NE Hungary. - Studia bot. bung. 27-28: 151-161.

PAPP B. \& RAJCZY M. (1998): Bryophyte flora of the branch-systems of the Danube in Szigetköz in 1991-1992. - Acta Bot. Hung. 40(1-4): 149-166.

PAPP B. \& RAJCZY M. (1998): Investigations on the condition of bryophyte vegetation of montain streams in Hungary. - J. Hattori Bot. Lab. 84: 81-90.

PAPP B. \& RAJCZY M. (1998): The role of Bryophytes as bioindicators of water quality in the Danube. - Verh. Internat. Verein. Limnol. 26(3): 1254-1256. https://doi.org/10.1080/03680770.1995.11900923

PÉNZESNÉ KóNYA E. \& ORBÁN S. (1998): A Bükk hegység radiolarit alapkőzetủ területeinek mohaflórája. (Bryophyte-flora of the radiolarite areas of the Bükk mountains (N-Hungary)). - Kitaibelia 3(2): 357-359.

Proctor M. C. F., Nagy Z., Csintalan Zs. \& Takács Z. (1998): Water-content components in bryophytes: analysis of pressure-volume relationships. - J. Exp. Bot. 49(328): 1845-1854. https://doi.org/10.1093/jxb/49.328.1845

SzövÉNYi P. (1998): A kőszegi tőzegmohás lápok. (Die zwei Kőszeger Moore). - Kitaibelia 3(1): 81.

SZURDOKI E. \& ÓDOR P. (1998): Evaluation of bryoflora of Bakony hills and Balaton region, Hungary, on the basis of the European Red Data Book of Bryophytes. In The 3rd European Conference on the Conservation of Bryophytes. Program \& Abstracts, 31.8.-4.9.1998. Trondheim.

Takács Z., Csintalan Zs., Lichtenthaler H. K. \& Tuba Z. (1998): Ecophysiological responses of the desiccation tolerant moss, Tortula ruralis to elevated $\mathrm{CO}_{2}$ level and heavy metal stress. - Garab Gy. (ed.): Photosynthesis: mechanisms and effects Volume V. Proceedings of the XIth international congress on photosynthesis. Budapest, Magyarország, August 17-22, 1998. Springer Science + Business Media, B. V., Dordrecht, pp. 4089-4092. https://doi.org/10.1007/978-94-011-3953-3_949

Tuba Z., Csintalan Zs., Szente K., Nagy Z. \& Grace J. (1998): Carbon gains by desiccation tolerant plants at elevated $\mathrm{CO}_{2}$. - Func. Ecol. 12(1): 39-44. https://doi.org/10.1046/j.1365-2435.1998.00173.x

Tuba Z., Proctor M. C. F. \& Csintalan Zs. (1998): Ecophysiological responses of homoiochlorophyllous and poikilochlorophyllous desiccation tolerant plants: a comparison and an ecological perspective. - Plant Growth Regulation 24(3): 211-217.

Vojt kó A. (1998): Relationships between the morphology of the spores of Hungarian Hepaticae species and their strategy types. - Studia bot. hung. 27-28: 109-115. 


\section{9}

BAKAlárné Sütő I. (1999): A tőzegmohák (Sphagnaceae) általános jellemzése. - In: FARKAS S. (ed.): Magyarország védett növényei. Mezőgazda Kiadó, Budapest, pp. 70-81.

Csintalan Zs., Proctor M. C. F. \& Tuba Z. (1999): Chlorophyll fluorescence during drying and rehydration in the mosses Rhytidiadelphus loreus (Hedw.) Warnst., Anomodon viticulosus (Hedw.) Hook. \& Tayl. and Grimmia pulvinata (Hew.) Sm. - Annals of Botany 84(2): 235-244. https://doi.org/10.1006/anbo.1999.0919

ERzBERgER P. (1999): Distribution of Dicranum viride and Dicranum tauricum in Hungary. - Studia bot. hung. 29: 35-47.

JAKAB G. (1999): Fosszilis mohák egy ópusztaszeri honfoglalás kori kútból. - Crisicum 2: 29-34.

LÁJER K. (1999): Florisztikai adatok a Dunántúlról, valamint Vácrátót környékéről. (Floristische Angaben aus Transdanubien und der Umgebung von Vácrátót (Donauebene)). - Kitaibelia 4(2): 311-317.

MARSCHALl M. (1999): Növényélettani és fotoszintézis-ökofiziológiai kutatások az egri föiskolán (tudománytörténeti áttekintés). - In: VARGA J. (ed.): MTA MAB Tudományos Konferencia. Eger, Magyarország, p. 37.

MARSCHALL M. (1999): Mohafajok bioindikátor szerepe és kiszáradás-toleranciájuk fiziológiai háttere. - PhD dolgozat, Kossuth Lajos Tudományegyetem, Debrecen.

Marschall M. \& Proctor M. C. F. (1999): Desiccation tolerance and recovery of the leafy liverwort Porella platyphylla (L.) Pfeiff.: Chlorophyll-fluorescence measurements. - J. Bryol. 21(4): 257-262. https://doi.org/10.1179/jbr.1999.21.4.257

Mázsa K., Mészáros R. \& Kalapos T. (1999): Ecophysiology of steppe mosses and lichens. - In: Kovács-Láng E., Molnár E., Kröel-Dulay Gy. \& Barabás S. (eds): Long term ecological research in the Kiskunság, Hungary. Kiskun LTER, Institute of Ecology and Botany, Hungarian Academy of Sciences, Vácrátót, pp. 37-38.

Nagy J., Figeczky G., Molnár M. \& SelÉnyi M. (1999): Adatok a beregi tőzegmohás lápok vegetációjának változásaihoz. (Data on the changes in the vegetation of peat bogs in Bereg (NE-Hungary)). - Kitaibelia 4(1): 193-195.

Orbán S. (1999): Általános bryológia. - Líceum Kiadó, Eger, 380 pp.

PAPP B. (1999): A védő-védtelen mohák. - Élet és Tudomány 54(3): 72-74.

PAPP B. \& RAJCZY M. (1999): Bryophytes of the Kiskunság National Park and of the other parts of the Danube-Tisza Interfluve. - In: Lőkös L. \& RAJCzy M. (eds): The flora of the Kiskunság National Park, Cryptogams. Magyar Természettudományi Múzeum, Budapest, pp. 363-413.

Pócs T. (1999): A löszfalak virágtalan növényzete I. Orografikus sivatag a Kárpát-medencében. (Studies on the cryptogamic vegetation of loess cliffs, I. Orographic desert in the Carpathian Basin). - Kitaibelia 4(1): 143-156.

RajCzy M. \& PAPp B. (1999): A vízi/vízparti mohavegetáció változása a Szigetközben (1991-1998). - In: LÁng I., BAnCzerowski J. \& Berczik Á. (eds): A Szigetköz környezeti állapotáról. MTA Szigetközi Munkacsoport, Budapest, pp. 113-118.

Szövényi P., Szurdoki E. \& Tóth Z. (1999): Új mohafajok előfordulása a Soproni- és Köszegihegységben. (Neue Moosarten aus dem Günser- und Soproner-Gebirge). - Kitaibelia 4(2): 329-330.

TAkács Z., Csintalan Zs., SAss L., Laitat E., VAss I. \& Tuba Z. (1999): UV-B tolerance of bryophyte species with different degree of desiccation tolerance. - J. Photochem. Photobiol. B: Biol. 48(2-3): 210-215. https://doi.org/10.1016/s1011-1344(99)00029-9

van Zanten B. O. (1999): Studies on the cryptogamic vegetation of loess cliffs II. The genus Bryum Hedw. on loess cliffs in the Pannonian Basin, including Bryum gemmiferum Wilcz. \& Demar. and Bryum violaceum Crundw. \& Nyh. new to Hungary. - Kitaibelia 4(1): 157-162. 
van Zanten B. O. (1999): Studies on the cryptogamic vegetation of loess cliffs, III. Ceratodon conicum (Hampe) Lindb., new to Hungary. - Kitaibelia 4(1): 163-164.

\section{0}

BADACSONYi A., BATES J. W. \& Tuba Z. (2000): Effects of desiccation on phosphorus and potassium acquisition by a desiccation-tolerant moss and lichen. - Annals of Botany 86(3): 621-627. https://doi.org/10.1006/anbo.2000.1228

BALOGH M. (2000): A lápok rendszerezése. - In: Szurdoki E. (ed.): Tözegmohás élőhelyek Magyarországon: kutatás, kezelés, védelem. CEEWEB Munkacsoport, Miskolc, pp. 57-65.

BALOGH M. (2000): Az úszóláp-szukcesszió kérdései I. (On the succession of floating bogs I.). - Kitaibelia 5(1): 9-16.

Beckett R. P., Csintalan Zs. \& Tuba Z. (2000): ABA treatment increases both the desiccation tolerance of photosynthesis and nonphotochemical quenching in the moss Atrichum undulatum. - Plant Ecology 151(1): 65-71. https://doi.org/10.1023/A:1026546707649

Csintalan Zs., Takács Z., Proctor M. C. F., Nagy Z. \& Tuba Z. (2000): Early morning photosynthesis of the moss Tortula ruralis following summer dew-fall in a Hungarian temperate dry sandy grassland. - Plant Ecol. 151(1): 51-54. https://doi.org/10.1023/a:1026590506740

ERZBERGER P. \& PAPP B. (2000): Orthotrichum sprucei discovered in continental Central Europe. - Herzogia 14: 213-215.

Hamerlynck E. P., Tuba Z., Csintalan Zs., Nagy Z., Henebry G. \& Goodin D. (2000): Diurnal variation in photochemical efficiency and surface reflectance of the desiccation-tolerant moss, Tortula ruralis. - Plant Ecol. 151(1):55-63. https://doi.org/10.1023/A:1026594623578

JAKAB G. \& MAGYARI E. (2000): Új távlatok a magyar lápkutatásban: szukcessziókutatás paleobryológiai és pollenanalitikai módszerekkel. (Progress in Hungarian mire succession studies: the use of palaeobryological and palynological techniques in the reconstruction of hydroseres). - Kitaibelia 5(1): 17-36.

Juhász A., BenKö Zs., Csintalan Zs. \& TuBA Z. (2000): A Tortula ruralis fotoszintézis-ökológiai sajátosságainak szezonális változásai. - Acta Biol. Debr., Suppl. Oecol. Hung. Fasc. 11(1): 239.

KirÁLY G. \& HoRVÁTH F. (2000): Magyarország flórájának térképezése: lehetőségek a térképezés hálórendszerének megválasztására. (Kartierung der Flora Ungarns: Möglichkeiten für die Auswahl des Kartierungsnetzes). - Kitaibelia 5(2): 357-368.

Kis G. \& TuвA Z. (2000): Contribution to the bryoflora of the Hungarian Bodrogköz. - Acta Bot. Hung. 42(1-4): 193-203.

Kun A., ItTzÉs P., Facsar G. \& HöHn M. (2000): Sziklagyepek és lejtősztyeppek a Középdunai Flóraválasztó környékén II. Mészkő- és dolomitvegetáció a Cserhát-hegységben. (Rocky grasslands and steppe slopes in the region of Middle-Danubian flora boundary. Dolomite and limestone vegetation in the Cserhát Hills). - Kitaibelia 5(1): 209-215.

LÁJER K. (2000): Helyreigazítás: egyes mohaadatok revíziója. - Kitaibelia 5(2): 369.

MAgyari E., JAKAB G., SÜMEgi P., Rudner E. \& MolnáR M. (2000): Paleobotanikai vizsgálatok a keleméri Mohos-tavakon. - In: SZURDOKI E. (ed.): Tőzegmohás élőhelyek Magyarországon: kutatás, kezelés, védelem. CEEWEB Munkacsoport, Miskolc, pp. 101-131.

MARSChall M. \& LAUfer Zs. (2000): Carbohydrates and the main characteristics of their metabolism in fructan-synthetising bryophytes. - Plant Physiol. Biochem. 38: 127.

Marschall M., Proctor M. C. F. \& Smirnoff N. (2000): Aspects of the photosynthetic responses of bryophytes. - J. Exp. Bot. Suppl. 51: 58.

ÓDOR P. (2000): Új faj a hazai mohaflórában: az Anastrophyllum hellerianum (Nees ex Lindenb.) Schust. (New species in the Hungarian bryoflora: Anastrophyllum hellerianum (Nees ex Lindenb.) Schust.). - Kitaibelia 5(1): 111-113. 
ÓDOR P. (2000): Kékes Észak Erdőrezervátum mohaflórája és mohavegetációjának jellemzése. (Description of the bryoflora and bryophyte vegetation of Kékes North Forest Reserve in Mátra mountains (North-Hungary)). - Kitaibelia 5(1): 115-123.

ÓDOR P. \& PAPP B. (2000): Korhadó fán élő mohák preferenciái hegyvidéki üde lomberdeinkben. - Acta Biol. Debr., Suppl. Oecol. Hung. Fasc. 11(1): 116.

Ódor P. \& STANDovár T. (2000): A mohavegetáció aljzatspecificitása és szerkezete egy természetközeli hegyvidéki bükkös erdőben. - Acta Biol. Debr., Suppl. Oecol. Hung. Fasc. 11(1): 286.

ORBÁN S. (2000): A löszfalak moháinak életstratégiái. (Life strategies of bryophytes of loess cliffs). - Acta Biol. Debr., Suppl. Oecol. Hung. Fasc. 11 (1): 117.

PAPP B. \& ERzBerger P. (2000): A Villányi-hegység mohaflórája (Bryophyta). (The bryophyte flora of the Villány Hills, South Hungary). - Dunántúli Dolg. Term. Tud. Sorozat 10: 37-45.

PApp B., Ódor P. \& ERzberger P. (2000): Preliminary data about the present Hungarian local populations of rare European bryophytes. - Studia bot. hung. 30-31: 95-111.

PAPP B. \& RAJCZY M. (2000): Bryophytes of saline-alkali areas of the Danube-Tisza Interfluve, Hungary. - Lindbergia 25(2-3): 134-139.

PAPP B. \& RAJCZY M. (2000): Contributions to the knowledge of the bryophytes of the forests along the Fekete-Körös, SE Hungary. - Studia bot. hung. 30-31: 57-67.

PAPP B. \& RAJCZy M. (2000): A vízi-vízparti mohavegetáció változása a Szigetközben (1991-1999). - Acta Biol. Debr., Suppl. Oecol. Hung. Fasc. 11 (1): 123.

PÉNZESNÉ KóNYA E. (2000): Mohafajok térbeli mintázatának vizsgálata radiolarit alapkőzetű területeken. - Acta Biol. Debr., Suppl. Oecol. Hung. Fasc. 11 (1): 291.

PÉNZESNÉ KóNYA E. \& ORBÁN S. (2000): A Bükk hegység radiolarit alapkőzetü területeinek mohaflórája II. (The bryophyte flora of radiolarite bedrock in the Bükk mountains II). Kitaibelia 5(1): 125-130.

Pócs T. (2000): Gondolatok szárazságtürö növényeink származásáról. - In: VIRÁGH K. \& KUN A. (eds): Vegetáció és dinamizmus. MTA Ökol. Bot. Kut. Int., Vácrátót, pp. 239-242.

Pócs T. (2000): Botanikai kutatások 50 esztendeje az Egri Tanárképző Főiskola Növénytani Tanszékén. - In: OrbáN S. (ed.): 50 éves a biológia oktatás Egerben. Magyar Tudomány Napja '99 Konferencia előadásainak összefoglalói. Nyíregyháza, Hungary, 3-5 November 1999. Eszterházy Károly Főiskola Biológiai és Környezettudományi Intézet, Eger, pp. 34-36.

Pócs T. (2000): Bryological activities at the Eger College, Hungary, during the past two years. - The Bryological Times 102: 7.

SzURDOKI E. (2000): A hazai lápokkal foglalkozó irodalmak összegyüjtése (Bibliográfia). - In: SzURDOKI E. (ed.): Tőzegmohás élőhelyek Magyarországon: kutatás, kezelés, védelem. CEEWEB Munkacsoport, Miskolc, pp. 155-182.

SzURDOKI E. (ed.) (2000): Tözegmohás élóhelyek Magyarországon: kutatás, kezelés, védelem. CEEWEB Munkacsoport, Miskolc, $184 \mathrm{pp}$.

Szurdoki E., Tóth Z. \& Pelles G. (2000): The Sphagnum populations of the Zemplén Mountains, NE Hungary. - Studia bot. hung. 30-31: 113-125.

TAKÁcs Z., Lichtenthaler H. K. \& TUBA Z. (2000): Fluorescence emission spectra of desiccation tolerant cryptogamic plants during a rehydration-desiccation cycle. $-\mathrm{J}$. Plant Physiol. 156(3): 375-379. https://doi.org/10.1016/s0176-1617(00)80076-0

van ZANTEN B. O. (2000): Studies on the cryptogamic vegetation of loess cliffs, IV. Chenia leptophylla (C. Müll.) Zander, new to Hungary. - Kitaibelia 5(2): 271-274.

\section{1}

BAdacsonyi A. \& Tuba Z. (2001): A környezet állapotának jelzése mohákkal. - Bot. Közlem. 86-87(1-2): 207-219. 
BALOGH M. (2001): Az úszóláp-szukcesszió kérdései II. Az úszólápok növényzetének szukcessziója. (Die Fragen der Sukzession der schwimmenden Moorvegetation). - Kitaibelia 6(2): 291-297.

BARINA Z. (2001): Felhagyott homokbányák florisztikai vizsgálata II. (Floristic investigation of Hungarian abandoned sand-pits II). - Kitaibelia 6(1): 157-165.

Csintalan Zs., Tuba Z., Takács Z. \& Laitat E. (2001): Responses of nine bryophyte and one lichen species from different microhabitats to elevated UV-B radiation. - Photosynthetica 39(2): 317-320. https://doi.org/10.1023/A:1013717628481

Dulai S., Orbán S., Horváth F., Csizi K., Marschall M. \& Molnár I. (2001): A növekvő tilakoid energizáltság és a csökkenő víztartalom hatása a fotoszintetizáló apparátus hőmérsékleti stabilitására Homalothecium lutescensben in vivo. In: IV. Magyarországi Fotoszintézis Találkozó. Szeged, Magyarország. Poszter összefoglalók, p. 5.

Erzberger P. (2001): Ditrichum crispatissimum (Muell. Hal.) Paris, a new species of the Hungarian bryoflora, and Ditrichum flexicaule (Schleich. ex Schwaegr.) Hampe in Hungary. Studia bot. hung. 32: 87-105.

KALAPOS T. \& MÁzSA K. (2001): Juniper shade enables terricolous lichens and mosses to maintain high photochemical efficiency in a semiarid temperate sand grassland. - Photosynthetica 39(2): 263-268.

Magyari E., Sümegi P., Braun M., Jakab G. \& MolnáR, M. (2001): Retarded wetland succession: anthropogenic and climatic signals in a Holocene peat bog profile from north-east Hungary. - J. Ecol. 89(6): 1019-1032. https://doi.org/10.1111/j.1365-2745.2001.00624.x

Marschall M., Proctor M. C. F., Smirnoff N. \& Dulai S. (2001): Mohafajok fotoszintetikus válaszainak sajátosságai. - In: IV. Magyarországi Fotoszintézis Találkozó. Szeged, Magyarország. Poszter összefoglalók, p. 11.

ÓDOR P. \& STANDOvÁR T. (2001): Richness of bryophyte vegetation in a near-natural and managed beech stands. The effects of management-induced differences in dead wood. - Ecol. Bulletins 49: 219-229. https://doi.org/10.2307/20113278

PAPP B. (2001): A mohák. A növényvilág szálláscsinálói. - TermészetBúvár 56(5): 34-36.

PAPP B., ÓdOR P. \& SZURDoKI E. (2001): An overview of options and limitations in the monitoring of endangered bryophytes in Hungary. - Novit. Bot. Univ. Carol. 15: 45-58.

PAPP B., ÓDOR P. \& SZURDOKI E. (2001): Experiences of the monitoring of endangered bryophytes in Hungary. - In: VÁŇA J. (ed.): Abstracts and programme of the 4th European conference on the conservation of bryophytes. Průhonice, p. 6 .

Pócs T. (2001): Rare and endangered moss species of loess cliffs in the Danube Basin. - In: VÁŇA J. (ed.): Abstracts and programme of the 4th European conference on the conservation of bryophytes. Průhonice.

Sımon T. (2001): A havasi varázslófü (Circaea alpina L.) hazai cönológiája. (Die Zönologie der Alpin-Hexenkraut (Circaea alpina L.) in Ungarn). - Bot. Közlem. 88(1-2): 107-116.

SzaBó L. Gy. (2001): Emlékek Boros Ádámról. - Kitaibelia 6(1): 199-206.

SZÖvÉNYi P., GALAMBos I. \& Hock Zs. (2001): A Soproni-hegység mohaflórája. (Bryophyte flora of the Sopron Mts.). - Tilia 10: 5-180.

Szurdoki E., Ódor P., TímÁr G. \& TóTH Z. (2001): Tőzegmohás élőhelyek térképezése a VasiHegyhát területén. (Habitat mapping of peat mosses in the area of the Vasi-Hegyhát (Western Hungary)). - Természetvédelmi Közlem. 9: 111-149.

TAKÁcs Z., Tuba Z. \& SMirnoff N. (2001): Exaggeration of desiccation stress by heavy metal pollution in Tortula ruralis: a pilot study. - Plant Growth Regulation 35(2): 157-160. https://doi.org/10.1023/A:1014481704892

Tuba Z. (2001): Bryophytes, the desiccation-tolerance and the elevated $\mathrm{CO}_{2} \cdot-$ Biol. Bull. Poznan 38: 226-228. 


\section{2}

Anonymus (2002): Beszélgetés Dr. Pócs Tamás akadémikussal - Barangolás a mohák birodalmában. - Élet és Tudomány 57(48): 1516-1518.

BALogh M. (2002): Az Örségi Tájvédelmi Körzet úszólápjai. - Kanitzia 10: 203-210.

BAlogh M. \& Zöld-BAlogh Á. (2002): Domboldali dagadóláp hazánkban. - Kanitzia 10: $211-216$

Dulai S., Horváth F., Orbán S., Darkó É., Csizi K. \& Molnár I. (2002): Water deficit under continuous light enhances the thermal stability of photosystem II in Homalothecium lutescens moss. - Acta Biol. Szeged. 46(3-4): 159-160.

ERzBerger P. (2002): Funaria muhlenbergii and Funaria pulchella (Funariaceae, Bryophyta) in Hungary. - Studia bot. hung. 33: 47-63.

ERzBerger P. (2002): Minor contribution to the bryoflora of the Cserhát Mts (Hungary). - Studia bot. hung. 33: 41-45.

Hamerlynck E. P., Csintalan Zs., Nagy Z., Tuba Z., Goodin D. \& Henebry G. (2002): Photosynthetic acclimation to altered light environment in the desiccation tolerant moss, Tortula ruralis (Hedw.) Gaertn. et al. - Oecologia 131(4): 498-505. https://doi.org/10.1007/s00442-002-0925-5

Носк Zs. (2002): Három dolomit sziklagyep moha-diaspórabankjának összehasonlitása a Csíkihegyekben (kezdeti eredmények). - In: HoRváth A. (ed.): Aktuális flóra- és vegetációkutatás a Kárpát-medencében V., Összefoglalók, Pécs, pp. 100-101.

JakAb G., MAgrari E. \& SÜMEgi P. (2002): Paleobotanikai adatok a Kalocsai-Sárrét vegetációs fejlődéséhez. - In: Horváth A. (ed.): Aktuális flóra- és vegetációkutatás a Kárpát-medencében V., Összefoglalók, Pécs, pp. 58-59.

Juhász A., Balogh J., Csintalan Zs. \& Tuba Z. (2002): Carbon sequestration of the poikilohydric moss carpet vegetation in semidesert sandy grassland ecosystem. - Acta Biol. Szeged. 46(3-4): 223-225.

KÜRSCHNER H. (2002): Life strategies of Pannonian loess cliff bryophyte communities: Studies on the cryptogamic vegetation of loess cliffs, VIII. - Nova Hedwigia 75(3-4): 307-318. https://doi.org/10.1127/0029-5035/2002/0075-0307

KüRSCHNER H. \& Pócs T. (2002): Bryophyte communities of the loess cliffs of the Pannonian Basin and adjacent areas, with the description of Hilpertio velenovskyi-Pterygoneuretum compacti ass. nov. - Studies on the cryptogamic vegetation of loess cliffs, VI. - Nova Hedwigia 75(1-2): 101-119. https://doi.org/10.1127/0029-5035/2002/0075-0101

LÁJer K. (2002): Az Örségi Tájvédelmi Körzet lápi és mocsári növénytársulásai. - Kanitzia 10: $175-202$.

MARSCHALl M. \& LAUfer Zs. (2002): Metabolic activity of Sphagnum recurvum under different environmental conditions. - Acta Biol. Szeged. 46(3-4): 247-248.

Mázsa K., Kalapos T. \& Draskovits R. (2002): Fotoszintézis-válaszreakciók és élőhelymozaikpreferencia összefüggése talajlakó xeroterm zuzmóknál és moháknál. - In: BÁLDI A. et al:: Szupraindividuális biológiai kutatások. MTA ÖBKI, Vácrátót, pp. 41-46.

NAGY J. (2002): A beregi lápok vegetációfejlödése. - In: Horváth A. (ed.): Aktuális flóra- és vegetációkutatás a Kárpát-medencében V., Összefoglalók, Pécs, pp. 45-46.

NAGY J. (2002): Szündinamikai vizsgálatok egy tözegmohaláp természeti értékeinek megörzésére. $\mathrm{PhD}$ dolgozat, Szent István Egyetem, Biológiai Doktori Iskola, Gödöllö, 206 pp.

Ódor P., PAPP B. \& Szurdoki E. (2002): Attekintés a mohafajok védelmének szakmai alapjairól Európában és hazánkban. - In: Lengyel Sz., Szentirmai I., BÁldi A., Horváth M. \& LENDVAi Á. (eds): Az 1. Magyar Természetvédelmi Biológiai Konferencia program és absztraktkötete. Magyar Biológiai Társaság, Budapest, p. 62. 
Ódor P. \& STANDOVÁR T. (2002): Substrate specificity and community structure of bryophyte vegetation in a near-natural montane beech forest. - Community Ecology 3(1): 39-49. https://doi.org/10.1556/comec.3.2002.1.5

ÓDor P., SZuRdoki E. \& TóTH Z. (2002): Az Örségi Tájvédelmi Körzet főbb élőhelyeinek mohavegetációja. (The bryophyte vegetation of important habitats in the Örség Protected Landscape Area (Hungary)). - Kanitzia 10: 15-60.

Orbán S. (2002): A löszfalak moháinak életstratégiái. - In: SAlamon-Albert É. (ed.): Magyar botanikai kutatások az ezredfordulón: Tanulmányok Borhidi Attila 70. születésnapja tiszteletére. PTE Növénytani Tanszék, Pécs, pp. 581-588.

PAPp B., Ódor P. \& SzURdoKi E. (2002): A Berni Konvencióban szerepló mohafajok veszélyeztetettségi helyzete Magyarországon és a monitoring nehézségei. - In: HoRvÁTH A. (ed.): Aktuális flóra- és vegetációkutatás a Kárpát-medencében V., Összefoglalók, Pécs, pp. 22-23.

PÉNZESNÉ KóNYA E. (2002): Mohafajok térbeli mintázatának és időbeli dinamikájának vizsgálata azonos alapközetü területeken. - In: HoRVÁTH A. (ed.): Aktuális flóra- és vegetációkutatás a Kárpát-medencében V., Összefoglalók, Pécs, pp. 65-66.

PÉNZESNÉ KóNYA E. (2002): Vadzavarás hatása Leucobryum juniperoideum térbeli mintázatára. In: Lengyel Sz., Szentir mai I., BÁldi A., Horváth M. \& Lendvai Á. (eds): Az 1. Magyar Természetvédelmi Biológiai Konferencia program és absztraktkötete: Veszélyeztetett fajok védelme. Magyar Biológiai Társaság, Budapest, Nyugat-Magyarországi Egyetem, Sopron, pp. $1-2$.

Söderström L., Urmi E. \& VÁŇA J. (2002): Distribution of Hepaticae and Anthocerotae in Europe and Macaronesia. - Lindbergia 27: 3-47.

SZÖVÉNYI P. (2002): The phorophyte preferences of epiphytic bryophytes in a Carici brizoidisAlnetum alliance in NW Hungary. - MSc értekezés, ELTE, TTK, Budapest.

SzÖVÉNYI P. (2002): Epifiton mohafajok fafaj preferenciájának vizsgálata hegyvidéki patakmenti égerligetben (terepi és kisérletes vizsgálatok). The phorophyte preferences of epiphytic bryophytes in a Carici brizoidis-Alnetum alliance in NW Hungary (field and experimental studies). - In: HoRvátr A. (ed.): Aktuális flóra- és vegetációkutatás a Kárpát-medencében V., Összefoglalók, Pécs, pp. 66-68.

SZURDOKI E. \& NAGY J. (2002): Sphagnum dominated mires and Sphagnum occurrences of NorthHungary. - Folia Hist.-nat. Mus. Matr. 26: 67-84.

Tuba Z., Csintalan Z., Szente K., Nagy Z. \& Grace J. (2002): Carbon gains by desiccationtolerant plants at elevated $\mathrm{CO}_{2}$. - Functional Ecol. 12(1):39-44.

https://doi.org/10.1046/j.1365-2435.1998.00173.x

VERESS M. (2002): Néhány bakonyi patakmeder mésztufa kiválásainak morfogenetikai típusai. Hidrol. Közl. 82(1): 15-22.

\section{3}

Badacsonyi A., Csintalan Zs. \& Tuba Z. (2003): Mohatranszplantációs bioindikáció alkalmazása a nehézfém-terhelés kistáj térléptékü vizsgálata során. - In: DoмBos M. \& LAKNER G. (eds): VI. Magyar Ökológus Kongresszus. Előadások és poszterek összefoglalói. Gödöllö, 2003. augusztus 27-29, Bessenyei György Könyvkiadó, Nyíregyháza, p. 26.

Fodor A. \& Szurdoki E. (2003): Nyugat-Magyarország tözegmoha elöfordulásai. - In: Dombos M. \& LAKNER G. (eds): VI. Magyar Ökológus Kongresszus. Elöadások és poszterek összefoglalói. Gödöllő, 2003. augusztus 27-29, Bessenyei György Könyvkiadó, Nyíregyháza, p. 89.

Hock Zs. (2003): Dolomit sziklagyepek kriptogám diaspóra bankjának vizsgálata. (Diaspore bank of bryophytes and ferns in grasslands on dolomite rock). - MSc értekezés, ELTE, TTK, Budapest. 
Hock Zs., Szövényi P. \& Tóth Z. (2003): A moha-diaspórabank szezonális változásainak vizsgálata dolomit sziklagyepekben. - In: Dомвоs M. \& LAKNER G. (eds): VI. Magyar Ökológus Kongresszus. Előadások és poszterek összefoglalói. Gödöllő, 2003. augusztus 27-29, Bessenyei György Könyvkiadó, Nyíregyháza, p. 111.

Juhász A., Balogh J., Csintalan Zs. \& Tuba Z. (2003): Mérsékeltövi félsivatagi homokpusztagyep Tortula ruralis mohaszönyegeinek éves szénmérlege. - In: Dombos M. \& LAKNER G. (eds): VI. Magyar Ökológus Kongresszus. Előadások és poszterek összefoglalói. Gödöllő, 2003. augusztus 27-29, Bessenyei György Könyvkiadó, Nyíregyháza, p. 125.

Juhász I., SÜMEgi P., Ja Kab G., SzÁntó Zs. \& MolnÁr M. (2003): Jégkorszaki reliktum Sphagnum láp Magyarországon. - In: Dombos M. \& LAKNER G. (eds): VI. Magyar Ökológus Kongresszus. Előadások és poszterek összefoglalói. Gödöllö, 2003. augusztus 27-29, Bessenyei György Könyvkiadó, Nyíregyháza, p. 126.

KozÁk I. O., KozÁk M., Fekete J. \& Sharma V. K. (2003): Concentration of Polycyclic Aromatic Hydrocarbons (PAHs) in moss (Hypnum cupressiforme) from Hungary. - J. Envir. Sci. Health, Part A 38(11): 2613-2619. https://doi.org/10.1081/ese-120024450

LÁJER K. (2003): A Caricetum buekii, Caricetum cespitosae, Caricetum paniceo-nigrae, Cirsietum rivularis és Sagittario-Sparganietum emersi hazai előfordulásáról. (Occurrence of Caricetum buekii, Caricetum cespitosae, Sagittario-Sparganietum emersi, Caricetum paniceo-nigrae and Cirsietum rivularis in Hungary). - Kitaibelia 8(1): 35-42.

MARSCHALl M. \& LAUfer Zs. (2003): Carbohydrates and the main characteristics of their metabolism in fructan-synthetizing bryophytes. - Acta Acad. Paed. Agr., Sect. Biol. 23: 137-147.

Nagy J., NÉmeth N. \& FigeczKy G. (2003): Dynamics of Sphagnum cushions in the willow carr of Bence-tó mire (NE Hungary) and its nature conservation aspects. - Polish Bot. J. 48: 163-169.

ÓDOR P. (2003): The importance of coarse woody debris for bryophyte vegetation of semi natural beech forests. - PhD Thesis, Department of Plant Taxonomy and Ecology, Eötvös Loránd University, Budapest, $31 \mathrm{pp}$.

Ódor P., SILLER I. \& STANDováR T. (2003): A korhadó fák jelentösége a gombák, mohák és edényesek kompoziciójában természetközeli bükkösökben. - In: Dомвоs M. \& LA KNER G. (eds): VI. Magyar Ökológus Kongresszus. Előadások és poszterek összefoglalói. Gödöllö, 2003. augusztus 27-29, Bessenyei György Könyvkiadó, Nyíregyháza, p. 206.

Orbán S. (2003): In honour of the seventy-year-old Tamás Pócs. - Acta Bot. Hung. 45(3-4): 227258. https://doi.org/10.1556/abot.45.2003.3-4.1

Orbán S. (2003): Pócs Tamás, a trópusi bryológus. - Acta Acad. Paed. Agr., Sect. Biol. 24: 11-19.

ORBÁN S. (2003): Mohák. - In: SimON T. (ed.): Baktérium-, alga-, gomba-, zuzmó- és mohahatározó. Nemzeti Tankönyvkiadó, Budapest, pp. 715-820.

Orbán S. \& Tóth Z. (2003): Mohák. - In: JÁrai-KomLódi M. (ed.): A magyar flóra. Pannon Enciklopédia, Magyarország növényvilága. Urbis Kiadó, Budapest, pp. 100-109.

Ötvös E., PÁzmÁndi T. \& Tuba Z. (2003): First national survey of atmospheric heavy metal deposition in Hungary by analysing of mosses. - Science of Total Environment 309: 151-160. https://doi.org/10.1016/s0048-9697(02)00681-2

PAPP B. (2003): A Fülöpszállás környéki szikes tavak mohaflórájának állapotfelmérése. (Investigation on the bryophyte flora of saline-alkali lakes around Fülöpszállás (Central Hungary). Természetvédelmi Közlem. 10: 217-228.

PAPp B. \& ERzberger P. (2003): Data about the actual local populations of bryophyte species protected in Hungary. - Studia bot. hung. 34: 33-42.

PAPP B., ÓdOR P. \& SzURDOKI E. (2003): Különbözö éloóhelyek mohaszintjének hosszú távú dinamikai vizsgálata az NBmR keretében. Elözetes eredmények. - In: Doмвоs M. \& LAKNER G. 
(eds): VI. Magyar Ökológus Kongresszus. Előadások és poszterek összefoglalói. Gödöllő, 2003. augusztus 27-29, Bessenyei György Könyvkiadó, Nyíregyháza, p. 212.

PAPP B., Ódor P. \& SzURDOKI E. (2003): Threat status of some protected bryophytes in Hungary. - Acta Acad. Paed. Agr., Sect. Biol. 24: 189-200.

PÉNZESNÉ KónYA E. (2003): A Leucobryum juniperoideum (Brid.) C. Muell. új hazai előfordulásai. - Acta Acad. Paed. Agr., Nov. Ser.: Sect. Biol. 8: 133-137.

PÉnZes KónYA E. (2003): The effect of animal disturbance on the spatial pattern and dynamics of Leucobryum juniperoideum (Brid.) C. Muell. - Acta Acad. Paed. Agr., Sect. Biol. 24: 201-213.

Simon T. (2003): A Lunularia cruciata (L.) Lindb. régi-új hazai termőhelye. (The old-new home habitat of the Lunularia cruciata (L.) Lindb.). - Acta Acad. Paed. Agr., Sect. Biol. 24: 129-136.

SZÖvÉNYI P., HocK Zs. \& TóTH Z. (2003): A kéreg kémiai összetételének hatása epifiton mohafajok megtelepedési valószínűségére és további fejlődésére. - In: Dомвоs M. \& LAKNER G. (eds): VI. Magyar Ökológus Kongresszus. Előadások és poszterek összefoglalói. Gödöllő, 2003. augusztus 27-29, Bessenyei György Könyvkiadó, Nyíregyháza, p. 257.

SZURDOKI E. (2003): Peat mosses of North Hungary. - Studia bot. hung. 34: 55-79.

\section{4}

BAlOgh L., LöKös L., PAPP B. \& VASAs G. (2004): Herbarium Waisbeckerianum.1. Waisbecker Antal herbáriumának Piers Vilmos által összeállított gomba-, zuzmó- és mohagyűjteménye a szombathelyi Savaria Múzeumban. (Herbarium Waisbeckerianum.1. The fungi, lichens and bryophytes collection of Vilmos Piers in Savaria Museum, Szombathely). - Savaria, a Vas Megyei Múzeumok Értesitöje 28: 7-47.

Dulai S., Csizi K., Sass-Gyarmati A., Orbán S. \& Molnár I. (2004): Combined effects of thylakoid energisation level and water deficit on thermal stability of photosystem II in a dessication tolerant moss. - Acta Acad. Paed. Agr., Sect. Biol. 25: 127-138.

ERzBeRger P. \& PAPP B. (2004): Annotated checklist of Hungarian bryophytes. - Studia bot. hung. 35: $91-150$.

Fodor A. (2004): Nyugat-Magyarország tözegmoha elöfordulásai. - Szakdolgozat, ELTE, TTK, Biológiai Intézet, Budapest.

Hock Zs., SZövényi P. \& Tóth Z. (2004): A kriptogám diaspórabank összetétele dolomit sziklagyepekben. - In: SzABó I., HeRmAnN T. \& SzALóKY I. (eds): Aktuális flóra- és vegetációkutatás a Kárpát-medencében VI., Keszthely, 2004. Összefoglaló kötet. Veszprémi Egyetem, Georgikon Mezőgazdaságtudományi Kar, Növénytani és Növényélettani Tanszék, Keszthely, p. 103.

Hock Zs., SzövéNYi P. \& TóTH Z. (2004): Seasonal variation in the bryophyte diaspore bank of open grasslands on dolomite rock. - J. Bryol. 26: 285-292. https://doi.org/10.1179/174328204x19478

Juhász A., Balogh J., Csintalan Zs. \& Tuba Z. (2004): The influence of the seasonal waterregime change on the photosynthetic features and carbon-balance of the poikilohydric moss carpet vegetation. - In: HidvéGi Sz. \& Gyuricza Cs. (eds): Proceedings of the III. AlpsAdria Scientific Workshop: Dubrovnik, Croatia, 1-6 March 2004. Hungarian Academy of Sciences, Budapest, pp. 107-111.

Kis G. \& MolnÁr K. (2004): Adatok a Mátra hegység moha- és zuzmóflórájához. (Data to the bryophyte and lichen flora of the Mátra Mts). - Acta Acad. Paed. Agr.: Nov. ser. 25: 25-38.

Marschall M. \& Proctor M. C. F. (2004): Are bryophytes shade plants? Photosynthetic light responses and proportions of chlorophyll a, chlorophyll $\mathrm{b}$ and total carotenoids. - Annals of Botany 94(4): 593-603. https://doi.org/10.1093/aob/mch178 
Marschall M. \& Proctor M. C. F. (2004): Aspects of stress tolerance in bryophytes. - Acta Acad. Paed. Agr., Sect. Biol. 25: 113-126.

Naszradi T., Badacsonyi A., Németh N., Tuba Z. \& Batić F. (2004): Zinc, lead, cadmium and copper concentrations of meadow plants and mosses along the M3 motorway (Hungary) after the introduction of lead-free fuel. - J. Atmospheric Chem. 49(1-3): 593-603. https://doi.org/10.1007/s10874-004-1268-x

ÓDOR P. (2004): Kidőlt fákon megjelenö mohavegetáció szukcessziója a korhadás során. - In: SzABó I., HERMANN T. \& SzALóKY I. (eds): Aktuális flóra- és vegetációkutatás a Kárpát-medencében VI., Keszthely, 2004. Összefoglaló kötet. Veszprémi Egyetem, Georgikon Mezőgazdaságtudományi Kar, Növénytani és Növényélettani Tanszék, Keszthely, p. 109.

Ódor P. \& van HeEs A. F. M. (2004): Preferences of dead wood inhabiting bryophytes for decay stage, log size and habitat types in Hungarian beech forests. - J. Bryol. 26(2): 79-95. https://doi.org/10.1179/037366804225021038

Orbán S. \& SASS-Gyarmati A. (2004): Új adatok az Upponyi-hegység mohaflórájához. - Acta Acad. Paed. Agr., Sect. Biol. 25: 43-48.

Ötvös E., Kozák I. O., Fekete J., Sharma V. K. \& Tuba Z. (2004): Atmospheric deposition of polycyclic aromatic hydrocarbons (PAHs) in mosses (Hypnum cupressiforme) in Hungary. Science of Total Environment 330(1-3): 89-99. https://doi.org/10.1016/j.scitotenv.2004.02.019

PAPp B. (2004): A készüló új magyar moha vörös lista. - In: Szabó I., Hermann T. \& Szalóky I. (eds): Aktuális flóra- és vegetációkutatás a Kárpát-medencében VI., Keszthely, 2004. Összefoglaló kötet. Veszprémi Egyetem, Georgikon Mezőgazdaságtudományi Kar, Növénytani és Növényélettani Tanszék, Keszthely, p. 19.

PAPP B. (2004): Mohák és természetvédelem. (Bryophytes and conservation). - Magyar Múzeumok 10(4): 21-23.

PÉNZES-KóNYA E. (2004): Comparative analysis of the bryophyte vegetation in acidophilous forest communities in the Bükk Mts (NE Hungary). - Acta Bot. Hung. 46(3-4): 373-384. https://doi.org/10.1556/abot.46.2004.3-4.9

PÉNZESNÉ KóNYA E. (2004): Mészkerülö erdötársulások mohaszintjének összehasonlító elemzése. In: SzABó I., Hermann T. \& SzALó KY I. (eds): Aktuális flóra- és vegetációkutatás a Kárpátmedencében VI., Keszthely, 2004. Összefoglaló kötet. Veszprémi Egyetem, Georgikon Mezögazdaságtudományi Kar, Növénytani és Növényélettani Tanszék, Keszthely, p. 58.

PÉNZESNÉ KóNYA E. (2004): Új adatok a Leucobryum juniperoideum (Brid.) C. Muell. hazai elöfordulásairól. - In: SzABó I., Hermann T. \& SzALóKY I. (eds): Aktuális flóra- és vegetációkutatás a Kárpát-medencében VI., Keszthely, 2004. Összefoglaló kötet. Veszprémi Egyetem, Georgikon Mezőgazdaságtudományi Kar, Növénytani és Növényélettani Tanszék, Keszthely, p. 59.

Pócs T., Sabovljević M., Puche F., Segarra J. G. M., Gimeno C. \& Kürschner H. (2004): Crossidium laxefilamentosum Frey $\&$ Kürschner, new to Europe and to North Africa. $-J$. Bryol. 26(2): 113-124. https://doi.org/10.1179/037366804225021074

SZövÉNYi P., Hocк Zs. \& TóTH Z. (2004): Epifiton mohafajok regenerációs dinamikája és potenciálja a laboratóriumban. - In: Szabó I., Hermann T. \& SzALóKy I. (eds): Aktuális flóra- és vegetációkutatás a Kárpát-medencében VI., Keszthely, 2004. Összefoglaló kötet. Veszprémi Egyetem, Georgikon Mezőgazdaságtudományi Kar, Növénytani és Növényélettani Tanszék, Keszthely, p. 113.

SzövÉNYi P., HocK Zs. \& Tóth Z. (2004): Phorophyte preferences of epiphytic bryophytes in a stream valley in the Carpathian Basin. - J. Bryol. 26(2): 137-146. https://doi.org/10.1179/037366804225021092

SZURDOKI E. \& ÓDOR P. (2004): Distribution and expansion of Sphagnum fimbriatum Wils. in Hungary. - Lindbergia 29: 136-142. 
SzÜCs P. (2005): Mohaflorisztikai vizsgálatok a Fertőmelléki-dombsor területén. - In: SzABó I., HERMANN T. \& SzALóKy I. (eds): Aktuális flóra- és vegetációkutatás a Kárpát-medencében VI., Keszthely, 2004. Összefoglaló kötet. Veszprémi Egyetem, Georgikon Mezőgazdaságtudományi Kar, Növénytani és Növényélettani Tanszék, Keszthely, p. 62.

Tótн Z. \& SzURDoki E. (2004): Részletes vegetációtérképezés a Belső-Örség területén. - Tájökológiai lapok 2: 77-108.

\section{5}

Buczkó K. \& Wojtal A. (2005): Moss inhabiting siliceous algae from Hungarian peat bogs. Studia bot. hung. 36: 21-42.

Csintalan Zs., Juhász A., Benkö Zs., Raschi A. \& Tuba Z. (2005): Photosynthetic responses of forest-floor moss species to elevated $\mathrm{CO}_{2}$ level by a natural $\mathrm{CO}_{2}$ vents. - Cer. Res. Com. 33(1): 177-180. https://doi.org/10.1556/crc.33.2005.1.43

Erzberger P. (2005): The bulbilliferous species of Pohlia (Bryaceae, Musci) in Hungary. - Studia bot. hung. 36: 67-75.

Juhász A., Balogh J., Csintalan Zs. \& Tuba Z. (2005): The influence of the watercontent on the photosynthetic features and carbon balance of the poikilohydric moss carpet vegetation. - Cer. Res. Com. 33(1): 235-237. https://doi.org/10.1556/crc.33.2005.1.57

MarsChall M. \& BeCKetT R. P. (2005): Photosynthetic responses in the inducible mechanisms of desiccation tolerance of a liverwort and a moss. - Acta Biol. Szeged. 49(1-2): 155-156.

Molnár K., Sass-Gyarmati A., Kis G., Orbán S., Pénzesné Kónya E. \& Sántha T. (2005): Mohák, zuzmók és nagygombák florisztikai feldolgozása acidofil erdöállományokban a Bükk hegység területén. - In: Lengyel Sz., Sólymos P. \& KLein Á. (eds): A III. Magyar Természetvédelmi Biológiai Konferencia Program és Absztrakt kötete. Magyar Biológiai Társaság, Budapest, p. 169.

Ódor P., Heilmann-Clausen J., Christensen M., Siller I., Aude E., Piltaver A., van Dort K. \& WALlEYN R. (2005): A korhadó fán megjeleno” gomba és moha közösségek kompoziciója és diverzitása Európa bükköseiben. - In: Lengyel Sz., Sólymos P. \& KLEIN Á. (eds): A III. Magyar Természetvédelmi Biológiai Konferencia Program és Absztrakt kötete. Magyar Biológiai Társaság, Budapest, p. 180.

Ódor P., van Dort K. W., Aude E., Heilmann-Clausen J. \& Christensen M. (2005): Diversity and composition of dead wood inhabiting bryophyte communities in European beech forests. - Bol. Soc. Esp. Briol. 26-27: 85-102.

ÖTvös E. \& TuBA Z. (2005): Ecophysiology of mosses under elevated air $\mathrm{CO}_{2}$ concentration: overview. - Physiol. Mol. Biol. Plants 11: 65-70.

PAPP B., Ódor P. \& SzURDOKI E. (2005): Gyeptársulások mohavegetációjának dinamikai vizsgálata. - In: Lengyel Sz., Sólymos P. \& Klein Á. (eds): A III. Magyar Természetvédelmi Biológiai Konferencia Program és Absztrakt kötete. Magyar Biológiai Társaság, Budapest, p. 185.

PAPP B., Ódor P. \& Szurdoki E. (2005): Methodological overview and a case study of the Hungarian Bryophyte Monitoring Program. - Bol. Soc. Esp. Briol. 26-27: 23-32.

PÉNZES-KóNYA E. (2005): Fine-scale spatial and temporal changes in the population structure of terricolous bryophyte species in acidophilous forest communities: the state of bryophyte ecology. In: Bryophyte population and landscape analysis network (Bryoplanet) 15. Kéked, Magyarország, 2005, Összefoglalók, p. 15.

Pócs T. (2005): A globális felmelegedés jelei hazánk mohaflórájában. - In: JoRDÁN F. (ed.): A DNStől a globális felmelegedésig. A 70 éves Vida Gábor köszöntése. Scientia Kiadó, Budapest, pp. 149-157. 
Singh M.K., Juhász A., Csintalan Zs., Kaligaric M., Marek M., Urban O. \& Tuba Z. (2005): Preliminary estimation of bryophyte biomass and carbon pool from three contrasting different vegetation types. - Cer. Res. Com. 33(1): 267-270.

https://doi.org/10.1556/CRC.33.2005.1.65

Szücs P. (2005): Mohaflorisztikai vizsgálatok a Fertőmelléki-dombsor területén. (Survey of the bryoflora of Fertő Hills (West-Hungary)). - Kitaibelia 10(1): 24-44.

van ZANTEN B. O. (2005): Studies on the cryptogamic vegetation of loess cliffs, VIII. Dicranella howei Ren. \& Card., a new addition to the Hungarian bryoflora. - Kitaibelia 10(1): 45-47.

\section{6}

Fodor L., Török K., Horváth F., Ódor P., PApp B., PÁl-Fám F., Siller I. \& Szurdoki E. (2006): Results of the Hungarian biodiversity monitoring system: habitat mapping, mosses and macrofungi. - In: Book of Abstracts, 1st European Congress of Conservation Biology, 22-26 August 2006, Eger, Hungary, p. 110.

Hock Zs., Ódor P., PAPp B., SzövéNyi P., SZurdoki E. \& Tóth Z. (2006): Mohák. - In: Ujhelyi P. \& Molnár V. A. (eds): Élővilág Enciklopédia II. A Kárpát-medence gombái és növényei. Kossuth Kiadó, Budapest, pp. 79-103.

Hock Zs., SzövénYi P. \& Tóth Z. (2006): Diaspórabank, mint genetikai memória a Mannia fragrans populációiban. - In: Szentesi Á., SzövéNYI G. \& TöRök J. (eds): 7. Magyar Ökológus Kongresszus 2006. szeptember 4-6, Budapest. Előadások és poszterek összefoglalói, p. 84.

JAKAB G. \& SüMEgi P. (2006): Magyar vegetáció fejlődése a legújabb környezettörténeti adatok alapján I. A magyarországi lápok és tavak fejlődése és a reliktumkérdés. - Kitaibelia 11(1): p. 15.

KIs G. \& Pócs T. (2006): Supplementum and corrections of the non European types and list of exsiccata in the Eger Cryptogamic Herbarium (EGR). - Folia Hist.-nat. Mus. Matr. 30: 35-41.

Lhotsky B., Kröel-Dulay Gy., Garadnai J. \& Kovácsné Láng E. (2006): A kriptogám réteg szerepe az évelö nyílt homokpusztagyepben. - In: SzEnTEsi Á., SzövÉNYi G. \& TöRöK J. (eds): 7. Magyar Ökológus Kongresszus 2006. Budapest, Hungary. Előadások és poszterek összefoglalói, p. 133.

MÉszÁros Sz. \& ÓdOR P. (2006): Mohaközösségek dinamikája. Kolonizáció, eltűnés és túlélés holtfán élő mohaközösségekben. (Dynamics of moss communities: Colonisation, disappearance and survival in moss communities inhabiting dead wood). - Kitaibelia 11(1): 66.

Ódor P., Heilmann-Clausen J., Christensen M., Aude E., van Dort K. W., Piltaver A., Siller I., Veerkamp M. T., Walleyn R., Standovár T., van Hees A. F. M., Kosec J., Matočec N., Kraigher H. \& Grebenc T. (2006): Diversity of dead wood inhabiting fungi and bryophytes in semi-natural beech forests in Europe. - Biol. Conservation 131: 58-71. https://doi.org/10.1016/j.biocon.2006.02.004

Ódor P. \& MÉszÁros Sz. (2006): Korhadó fán megjelenő mohaközösségek dinamikája. - In: SzENTESI Á., SzÖvÉNYI G. \& TöRÖK J. (eds): 7. Magyar Ökológus Kongresszus 2006. szeptember 4-6, Budapest. Előadások és poszterek összefoglalói, p. 163.

OrBán S. (2006): Acidofil erdei és sziklai társulások mohaökológiai vizsgálata a Bükk hegységben. In: Kalapos T. (ed.): Jelez a flóra és a vegetáció. A 80 éves Simon Tibort köszöntjük. Scientia, Budapest, pp. 33-40.

PApp B. (2006): Védett mohák. - In: Ujhelyi P. \& Molnár V. A. (eds): Élővilág Enciklopédia II. A Kárpát-medence gombái és növényei. - Kossuth Kiadó, Budapest, p. 104.

PAPP B., Ódor P. \& SzURDoki E. (2006): A mohák monitorozásának eredményei. - In: TöRöK K. \& Fodor L. (eds): A Nemzeti Biodiverzitás-monitorozó Rendszer eredményei I. Élőhelyek, 
mohák és gombák. Környezetvédelmi és Vízügyi Minisztérium, Természetvédelmi Hivatal, Budapest, pp. 99-152.

PÉNZES-KónYA E. (2006): Fine-scale spatial and temporal changes in the population structure of terricolous bryophyte species in forest communities. - Acta Bot. Hung. 48(3-4): 381-394. https://doi.org/10.1556/abot.48.2006.3-4.12

PÉNZES-KóNYA E. (2006): Mohafaj-komplexek időbeli dinamikája különböző erdőtársulásokban. - Kitaibelia 11(1): 62.

PÉNZES-KónYA E. (2006): The main driving factors affecting the bryophyte vegetation of forest communities. In: Book of Abstracts, 1st European Congress of Conservation Biology, 22-26 August 2006, Eger, Hungary, p. 148.

Pócs T. (2006): A kryptobiotikus kéreg és szerepe a szárazföldi ökoszisztémákban. - In: VIzI E. Sz. \& BERTók K. (eds): Székfoglalók a Magyar Tudományos Akadémián, 2001, MTA, Budapest, pp. 439-478.

Rabnecz Gy., Pócs T., PAPP B., VÉgváRi Gy. \& TubA Z. (2006): Légköri nehézfémszennyezés nagy tér és idöléptékü összehasonlitó vizsgálata moha bioindikáció technikával Magyarországon és trópusokon. - In: Szentesi Á., SzövénYi G. \& Török J. (eds): 7. Magyar Ökológus Kongresszus 2006. Budapest, Hungary. Előadások és poszterek összefoglalói, p. 177.

STANDOVÁR T., ÓDOR P., AszaLós R. \& GÁLHIDY L. (2006): Sensitivity of ground layer vegetation diversity descriptors in indicating forest naturalness. - Community Ecology 7(2): 199-209. https://doi.org/10.1556/comec.7.2006.2.7

Szövényi P., Hock Zs., Urmi E. \& SChneller J. J. (2006): Contrasting phylogeographic patterns in Sphagnum fimbriatum and Sphagnum squarrosum (Bryophyta, Sphagnopsida) in Europe. - New Phytol. 172(4): 784-794. https://doi.org/10.1111/j.1469-8137.2006.01870.x

Szövényi P., Hock Zs., Urmi E. \& Schneller J. J. (2006): A Sphagnum fimbriatum Wils. és a S. squarrosum Crome Európa szintű infraspecifikus molekuláris filogeografikája: az életmenet és demográfia hatása. (Infraspecific molecular phylogeography of Sphagnum fimbriatum Wils. and S. squarrosum Crome in Europe: effects of life history and demography). Kitaibelia 11(1): 80.

SzURDoKi E. (2006): Tözegmohalápok és tözegmohák vizkémiai vizsgálata. - In: SzENTEsi Á., SzövÉNYI G. \& TÖRÖK J. (eds): 7. Magyar Ökológus Kongresszus 2006. Budapest, Hungary. Előadások és poszterek összefoglalói, p. 203.

Traser Gy., SzÜcs P. \& Winkler D. (2006): Collembola diversity of moss habitats in the Sopron region, NW-Hungary. - Acta Silv. Lign. Hung. 2: 69-80.

\section{7}

Csintalan Zs., Tuba Z., Ötvös E. \& RaBnecz Gy. (2007): Táj- és országos léptékű moha-bioindikációs módszerek és alkalmazásuk. - Magyar Tudomány 167(10): 1288-1295.

Hock Zs. (2007): Propagule banks in bryophytes and ferns: dynamics, genetic composition and the role of the life history. - PhD thesis, Zürich.

Kenderes K., Tímár G., Ódor P., Bartha D., Standovár T., Bodonczi L., Bölöni J., Szmorad F. \& Aszalós R. (2007): A természetvédelem hatása középhegységi erdeinkre. (The impact of conservation on the forests in the Hungarian mountain chain). - Természetvédelmi Közlem. 13: 69-80.

Naszradi T., Badacsonyi A., Keresztényi I., Podar D., Csintalan Zs. \& Tuba Z. (2007): Comparison of two metal surveys by moss Tortula ruralis in Budapest, Hungary. - Environ. Monit. Assess. 134(1-3): 279-285. https://doi.org/10.1007/s10661-007-9617-2

NÉmetн Cs. (2007): Data on the distribution of some rare alpine-boreal bryophytes in the Vértes Mts. (Hungary). - Studia bot. hung. 38: 59-70. 
Orbán S. (2007): A mohák törzsei. - In: Tuba Z., Szerdahelyi T., Engloner A. \& Nagy J. (eds): Botanika: bevezetés a növénytanba, algológiába, gombatanba és funkcionális növényökológiába. Tankönyvkiadó, Budapest, pp. 361-381.

PAPP B., Ódor P. \& SzURDOKI E. (2007): Bryophyte biodiversity monitoring system in Hungary, Eastern Central Europe. - Chenia 9: 143-158.

PÉNZESNÉ KóNYA E. (2007): Mohafajok térbeli mintázatának és időbeli dinamikájának vizsgálata radiolarit alapkőzetü területeken. - PhD disszertáció, ELTE, TTK, Budapest, 112 pp.

Pócs T. (2007): On the Research Group for Bryology of the Hungarian Academy of Sciences at the Eszterházy College, Eger, Hungary. - The Bryological Times 124: 11-13.

Rabnecz Gy., PApp B. \& VÉgváry Gy. (2007): Comparison of heavy metal deposition by large scale biomonitoring in Europe and tropical Africa. - Cer. Res. Com. 35(2): 961-965. https://doi.org/10.1556/crc.35.2007.2.199

Söderström L., URMi E. \& VÁŇA J. (2007): The distribution of Hepaticae and Anthocerotae in Europe and Macaronesia. Update 1-427. - Cryptog., Bryol. 28: 299-350.

Szücs P. (2007): A Campylopus introflexus Hedw. új hazai előfordulása az Ácsi-erdőben. - Kitaibelia 12(1): 145 .

Szücs P. (2007): Dunaalmás és Neszmély környékének mohaflórája. - Bot. Közlem. 94(1-2): $91-115$.

Szücs P. \& Erzberger P. (2007): Campylopus introflexus (Hedw.) Brid. (In: Blockeel T. L. (ed.): New national and regional bryophyte records, 16). - J. Bryol. 29(3): 199. https://doi.org/10.1179/174328207X209203

SzŰCS P. \& ERzBERger P. (2007): Ritka mohák előfordulása és termőhelyi viszonyai a Naszályhegyröl. - In: Poster at the Conference of Science, Nature conservation Section. EKTV-TK Konferencia Kiadvány, Sopron, pp. 166-167.

Tuba Z., Csintalan Zs., Nagy Z., Szente K. \& TAkács Z. (2007): Sampling of terricolous lichen and moss species for trace element analysis, with special reference to bioindication of air pollution. - In: MAR Kert B. (ed.): Environmental Sampling for Trace Analysis. VCH, Weinheim, New York, Basel, Cambridge, Tokyo, pp. 415-434. https://doi.org/10.1002/9783527615872.ch22

\section{8}

BAuer N., Lőkös L. \& PAPP, B. (2008): Distribution and habitats of Cardaminopsis petraea in Hungary. - Studia bot. hung. 39: 113-138.

Borosné KenYeres J. \& OrBán S. (2008): List of the scientific publications of Ádám Boros 19001973 (Verzeichnis der wissenschaftlichen Publikationen von Ádám Boros 1900-1973). - In: Szabó I. L. \& Szabó L. Gy. (eds): Boros Ádám Breviárium. Pannon Egyetem, Georgikon Kar, Keszthely, pp. 159-170.

Erzberger P. \& MAIER E. (2008): Grimmia decipiens (Schultz) Lindb. (In: Blockeel T. L. (ed.): New national and regional bryophyte records, 18). - J. Bryol. 30(2): 163. https://doi.org/10.1179/174328208X282463

Erzberger P. \& Maier E. (2008): Grimmia lisae De Not. (In: Blockeel T. L. (ed.): New national and regional bryophyte records, 18). - J. Bryol. 30(2): 163. https://doi.org/10.1179/174328208X282463

Erzberger P., Maier E. \& Szücs P. (2008): Grimmia elatior Bruch ex Bals.-Criv. \& De Not. (In: Blockeel T. L. (ed.): New national and regional bryophyte records, 18). - J. Bryol. 30(2): 163. https://doi.org/10.1179/174328208X282463

ERzberger P. \& SCHRöder W. (2008): The genus Schistidium (Grimmiaceae, Musci) in Hungary. - Studia bot. hung. 39: 27-88. 
Hock Zs., Szövényi P., SChneller J. J., URmi E. \& Tóth Z. (2008): Are sexual or asexual events determining the genetic structure of populations in the liverwort Mannia fragrans? - J. Bryol. 30(1): 66-73. https://doi.org/10.1179/174328208x282120

Hock Zs., Szövényi P., SChneller J. J., URmi E. \& Tóth Z. (2008): Bryophyte diaspore bank - a genetic memory? Genetic structure and genetic diversity of surface populations and diaspore bank in the liverwort Mannia fragrans (Aytoniaceae). - Amer. J. Bot. 95(5): 542-548. https://doi.org/10.3732/ajb.2007283

Hock Zs., Szövényi P., Tóth Z., SChneller J. J. \& URmi E. (2008): A szaporodási rendszer populációgenetikai következményei az illatos májmoha (Mannia fragrans) esetében. (Population genetic consequences of the reproductive system in the liverwort Mannia fragrans). Kitaibelia 13(1): 105.

Hock Zs., Szövényi P., Tóth Z., SChneller J. J. \& URmi E. (2008): Moha diaspórabank - genetikai memória? A Mannia fragrans felszíni populációinak és diaspórabank genetikai összetétele. (Bryophyte diaspore bank - a genetic memory? Genetic structure and genetic diversity of surface populations and diaspore bank in the liverwort Mannia fragrans). - Kitaibelia 13(1): 104.

JuHÁsz A., PÉLI E.R. \& BENKő Zs. (2008): Some photosynthetic features of desiccation-tolerant terricolous lichen and moss species transplanted to a natural $\mathrm{CO}_{2}$ vents: preliminary communication. - Cer. Res. Com. 36(Suppl.): 2015-2018.

KIRÁLY I. \& ÓdOR P. (2008): A faállomány változóinak hatása az őrségi erdők kéreglakó mohaközösségére. - In: Lengyel Sz., Miнó K B., Lendvai Á. Z. \& Sólymos P. (eds): „Molekuláktól a globális folyamatokig” V. Magyar Természetvédelmi Biológiai Konferencia. Nyíregyháza, 2008. november 6-9. Program és absztrakt-kötet. Magyar Biológiai Társasság, Budapest, p. 125.

Németr Cs. (2008): Adatok a Súri-Bakonyalja, a Bakony és a Vértes mohaflórájához. - Flora Pannonica 6: 79-87.

ORBÁN S. (2008): Acidofil erdőtársulások mohavegetációjának vizsgálata a Bükk hegységben. Kitaibelia 13(1): 123.

Orbán S. (2008): A magyarországi mohászat rövid története. - In: Szabó I. L. \& Szabó L. Gy. (eds): Boros Ádám Breviárium. Pannon Egyetem, Georgikon Kar, Keszthely, pp. 57-59.

Orbán S., Pénzesné Kónya E. \& Sass-Gyarmati A. (2008): Acidofil erdőtársulások kriptogám szinúziumainak florisztikai, cönológiai és ökológiai vizsgálata a Bükk hegységben. - Kitaibelia 13(1): 183 .

PAPP B. (2008): A mohák védelme Magyarországon kis kitekintéssel Európára (Conservation of bryophytes in Hungary with some outlook to Europe). - In: KRöEl-Dulay Gy., Kalapos T. \& Mojzes A. (eds): Talaj-vegetáció-klíma kölcsönhatások. Köszöntjük a 70 éves Láng Editet. (Interactions of soil-vegetation-climate. Congratulation to the 70 years old Edit Láng). MTA ÖBKI, Vácrátót, pp. 167-177.

PAPP B. (2008): Boros Ádám hagyatékának szerepe a mai mohászati kutatásokban. - In: SzABó I. L. \& Szabó L. Gy. (eds): Boros Ádám breviárium. Pannon Egyetem, Georgikon Kar, Keszthely, pp. 60-68.

PAPP B. (2008): Selection of Important Bryophyte Areas in Hungary. - Folia Cryptog. Estonica 44: 101-111.

PAPP B., Ódor P. \& SzURdoki E. (2008): Fontos mohavédelmi területek az Európai Vörös Könyves mohafajok védelmének lehetőségei. - In: Lengyel Sz., Miнó к B., Lendvai Á. Z. \& Sólymos P. (eds): „Molekuláktól a globális folyamatokig”. V. Magyar Természetvédelmi Biológiai Konferencia. Nyíregyháza, 2008. november 6-9. Program és absztrakt-kötet. Magyar Biológiai Társasság, Budapest, p. 95.

PÉli E. R., ÖTvös E., JuHÁsz A. \& BENKö Zs. (2008): Effects of elevated air $\mathrm{CO}_{2}$ concentrations on heavy metal content of terricolous mosses and lichens: a preliminary study of bioindication under doubled air $\mathrm{CO}_{2}$ concentration. - Cer. Res. Com. 36(Suppl.): 2011-2014. 
Rabnecz Gy., Csintalan Zs., Keresztényi I., IsaÁk Gy. \& Jócsák I. (2008): A water quality investigation around an oil refinery in Hungary using the Fontinalis antipyretica (Hedw.) as bioindicator. - Acta Biol. Szeged. 52(1): 75-77.

Szövényi P., Hock Zs., Korpelainen H. \& SHAw J. A. (2008): A migrációs nyomás és lokális adaptáció kapcsolatának vizsgálata egy modell mohafaj segítségével. (Migration load and local adaptation in a bryophyte model system). - Kitaibelia 13: 192.

Szurdoki E., HudÁx K. \& G. FARKAS T. (2008): A keleméri Mohos-tavak bibliográfiája. - In: BoLDogh S. \& G. FARKAS T. (eds): A keleméri Mohos-tavak. Kutatás, kezelés, védelem (ANP füzetek IV). Aggteleki Nemzeti Park Igazgatósága, Jósvafö, pp. 325-334.

Szurdoki E., Ódor P. \& PAPp B. (2008): A keleméri Mohos-tavak mohaflórája. (The bryophyte flora of Mohos lakes). - In: Boldogh S. \& G. FArkas T. (eds): A keleméri Mohos-tavak. Kutatás, kezelés, Védelem. (ANP füzetek IV). Aggteleki Nemzeti Park Igazgatóság, Jósvafő, pp. 65-95.

SzÜcs P. \& Erzberger P. (2008): A Hedwigia ciliata var. leucophaea Bruch et Schimp. érdekes előfordulása Komáromnál. - Bot. Közlem. 95(1-2): 155.

Tuba Z., Csintalan Zs., Szente K., Nagy Z., Fenete G., Larcher W. \&. Lichtenthaler H. K. (2008): Winter photosynthetic activity of twenty temperate semi-desert sand grassland species. - J. Plant Physiol. 165(14): 1438-1454. https://doi.org/10.1016/j.jplph.2007.10.017

\section{9}

Berényi P., Fodor A., Szövényi P. \& Szurdoki E. (2009): A köszegi alsó-erdei fiatal láp tözegmoha párnáinak változásai. - In: KörmöCzI L. (ed.): 8. Magyar Ökológus Kongresszus: Elöadások és poszterek összefoglalói. Szegedi Tudományegyetem, Szeged, p. 23.

Csintalan Zs. (2009): Dr. Tuba Zoltán (1951-2009). - Bot. Közlem. 96(1-2): 1-2.

Csintalan Zs., Fogarasi G. \& NAGy J. (2009): Tözegmohafajok kiszáradástürésének vizsgálata klorofill fluoreszcencia változás mérése alapján. - In: KöRMöczI L. (ed.): 8. Magyar Ökológus Kongresszus: Előadások és poszterek összefoglalói. Szegedi Tudományegyetem, Szeged, p. 47.

Erzberger P. (2009): Coscinodon cribrosus (Hedw.) Spruce. (In: Blockeel T. L. (ed.): New national and regional bryophyte records, 20). - J. Bryol. 31(1): 55. https://doi.org/10.1179/jbr.2009.31.1.64

Erzberger P. (2009): Pseudoleskea incurvata (Hedw.) Loeske. (In: Blockeel T. L. (ed.): New national and regional bryophyte records, 20). - J. Bryol. 31(1): 57. https://doi.org/10.1179/jbr.2009.31.1.64

ERzBerger P. (2009): Racomitrium aciculare (Hew.) Brid. (In: Blockeel T. L. (ed.): New national and regional bryophyte records, 20). - J. Bryol. 31(1): 57. https://doi.org/10.1179/jbr.2009.31.1.

ERzberger P. (2009): The genera Grimmia and Coscinodon (Grimmiaceae, Musci) in Hungary. Studia bot. hung. 40: 37-124.

ERzberger P. \& SCHRöder W. (2009): Schistidium confusum H. H. Blom. (In: Blockeel T. L. (ed.): New national and regional bryophyte records, 20). - J. Bryol. 31 : 58. https://doi.org/10.1179/jbr.2009.31.1.64

Fodor A., Szövényi P. \& Tót H Z. (2009): A ciprusmoha (Hypnum cupressiforme Hedw.) reprodukciós biológiája. In: KörmöczI L. (ed.): 8. Magyar Ökológus Kongresszus: Előadások és poszterek összefoglalói. Szegedi Tudományegyetem, Szeged, p. 67.

Hock Zs., Szövényi P., Schneller J. J., Urmi E. \& Tóth Z. (2009): Population genetic consequences of the reproductive system in the liverwort Mannia fragrans. - Plant Ecol. 202(1): 123-134. https://doi.org/10.1007/s11258-008-9541-8 
Jakab G., Sümegi P., Majkut P. \& Juhász I. (2009): Antropogén és klimatikus hatások szerepe a nagybárkányi Nádas-tó fejlődésében. - In: KöRmöczi L. (ed.): 8. Magyar Ökológus Kongresszus: Előadások és poszterek összefoglalói. Szegedi Tudományegyetem, Szeged, p. 96.

MARSCHALL M. (2009): Fruktántartalmú mohafajok metabolikus aktivitása különbözö környezeti tényezők függvényében. - In: KörmöczI L. (ed.): 8. Magyar Ökológus Kongresszus: Előadások és poszterek összefoglalói. Szegedi Tudományegyetem, Szeged, p. 145.

MÁrialigeti S., NéMETH B., Tinya F. \& Ódor P. (2009): The effects of stand structure on groundfloor bryophyte assemblages in temperate mixed forests. - Biodiversity and Conservation 18: 2223-2241. https://doi.org/10.1007/s10531-009-9586-6

NÉmeth Cs. (2009): Adatok a Dicranum tauricum Sapjegin hazai elterjedéséhez. - Flora Pannonica 7: $51-55$.

ORBÁN S. (2009): Acidofil erdötársulások moháinak életstratégiái a Bükk hegységben. - In: KöRMÖCZI L. (ed.): 8. Magyar Ökológus Kongresszus: Előadások és poszterek összefoglalói. Szegedi Tudományegyetem, Szeged, p. 168.

Orbán S., PÉnZesné Kónya E. \& Sass-Gyarmati A. (2009): Mészkerülő erdötársulások domináns mohafajainak mintázat vizsgálata. - In: Kör MöczI L. (ed.): 8. Magyar Ökológus Kongresszus: Előadások és poszterek összefoglalói. Szegedi Tudományegyetem, Szeged, p. 169.

ORBÁN S., PÉNZESNÉ KónYA E. \& SASS-GyARMATI A. (2009): Radiolarit és agyagpala alapkőzeten kialakult acidofil erdőtársulások kriptogám vegetációjának leírása a Bükk hegységből. - Acta Acad. Paed. Agr., Sect. Biol. 36: 3-20.

PAPP B. (2009): Introduction. - In: PAPP B. (ed.): The flora of the Aggtelek National Park. Cryptogams. Natural history of the national parks of Hungary, Magyar Természettudományi Múzeum, Budapest, Vol. 14: 9-12.

PAPp B. (2009): The bryophyte flora of the Aggtelek National Park. - In: PAPP B. (ed.): The flora of the Aggtelek National Park. Cryptogams. Natural history of the national parks of Hungary, Magyar Természettudományi Múzeum, Budapest, Vol. 14: 175-230.

PAPP B. (2009): Pohlia nutans (Hedw.) Lindb. subsp. schimperi (Müll. Hal.) Nyholm. (In: Bloc KeEL T. L. (ed.): New national and regional bryophyte records, 20). - J. Bryol. 31(1): 57. https://doi.org/10.1179/jbr.2009.31.1.64

PAPP B. (2009): Grimmia crinita Brid. (In BlockeEL T. L. (ed.): New national and regional bryophyte records, 21). - J. Bryol. 31(2): 134. https://doi.org/10.1179/174328209X431213

PAPP B. (2009): Gymnostomum viridulum Brid. (In: BlockeEL T. L. (ed.): New national and regional bryophyte records, 21). - J. Bryol. 31(2): 134-135. https://doi.org/10.1179/174328209X431213

PAPp B. (2009): Pohlia lescuriana (Sull.) Ochi. (In: BlockeEL T. L. (ed.): New national and regional bryophyte records, 21). - J. Bryol. 31(2): 136. https://doi.org/10.1179/174328209X431213

PAPP B., ÓDOR P. \& SzurdoKi E. (2009): Száraz gyepek mohaközösségének dinamikája. - In: KöRмöczI L. (ed.): 8. Magyar Ökológus Kongresszus: Előadások és poszterek összefoglalói. Szegedi Tudományegyetem, Szeged, p. 175.

PAPP B., RAJCZY M. (2009): Changes of aquatic-riparian bryophyte vegetation between 1991/92 and 2004 in the Szigetköz branch-system after the diversion of the Danube. - Acta Bot. Hung. 51(1-2): 129-145. https://doi.org/10.1556/abot.51.2009.1-2.15

PÉli E. R., Cserhalmi D. \& NAGy J. (2009): Két beregi tözegmohás élőhely szezonális ökofiziológiai vizsgálata. - In: Körmöczi L. (ed.): 8. Magyar Ökológus Kongresszus: Előadások és poszterek összefoglalói. Szegedi Tudományegyetem, Szeged, p. 178.

PÉNZESNÉ KóNYA E. (2009): Ivaros és vegetativ terjedési sajátosságok Dicranum fajoknál. - In: KöRмÖczı L. (ed.): 8. Magyar Ökológus Kongresszus: Előadások és poszterek összefoglalói. Szegedi Tudományegyetem, Szeged, p. 179. 
PÉNZESNÉ KóNYA E. (2009): The examination of spatial heterogeneity of the terricolous bryophyte vegetation in acidofil forest communities. - Acta Acad. Paed. Agr., Nov. Ser.: Sect. Biol. 13: 69-89.

Rabnecz Gy. \& Csintalan Zs. (2009): Nagy tér- és időléptékủ moha bioindikáció. - Bot. Közlem. 96(1-2): 21-22.

Rabnecz Gy., Keresztényi I., IsaÁk Gy., Jócsák I., Varga Zs. \& Péli E. (2009): A biomonitoring investigation around an oil refinery in Hungary based on mosses. - Acta Bot. Hung. 51(1-2): 179-184. https://doi.org/10.1556/abot.51.2009.1-2.17

Sass L, Csintalan Zs., Tuba Z. \& VAss I. (2009): A fotoszintetikus apparatátus müködése és UV toleranciája kiszáradástürő zuzmókban és mohákban. - Bot. Közlem. 96(1-2): 27-28.

SZURDoki E., MAJOR Á. \& SzÖvÉNYi P. (2009): A Sphagnum recurvum fajcsoport vizsgálata. - In: Körmöczı L. (ed.): 8. Magyar Ökológus Kongresszus: Előadások és poszterek összefoglalói. Szegedi Tudományegyetem, Szeged, p. 215.

Szűcs P. (2009): A Campylopus introflexus (Hedw.) Brid. új hazai adata a Bockerek-erdőből. Kitaibelia 14(1): 123.

SzÜcs P. (2009): Mohaadatok az Agostyáni Arborétumból. - Komárom-Esztergom Megy. Múz. Közlem. 15: 159-164.

Szücs P. (2009): Mohaflorisztikai vizsgálatok az Örség területén. - Praenorica Folia HistoricoNaturalia 11: 13-48.

SzÜCs P. \& SzMORAD F. (2009): Ergänzungen zur Moosflora des Ödenburger Gebirges (Kiegészítések a Soproni-hegység mohaflórájához). - Flora Pannonica 7: 61-72.

Tinya F., Márialigeti S., Király I., Németh B. \& Ódor P. (2009): The effect of light conditions on herbs, bryophytes and seedlings of temperate mixed forests in Örség, Western Hungary. - Plant Ecol. 204: 69-81. https://doi.org/10.1007/s11258-008-9566-z

\section{0}

BODORNÉ JUHÁsz A. (2010): Syntrichia ruralis szénmérlege, ökofiziológiai és növekedési sajátosságai száraz homokpusztagyepben, és kriptogám fajok válaszreakciói a növekvő légköri $\mathrm{CO}_{2}$ szintre. - Doktori értekezés tézisei, Szent István Egyetem, Gödöllő, 20 pp.

Dulai S. \& Molnár I. (2010): A csökkenö viztartalom hatása a PS II. hömérsékleti stabilitására eltérö fényklimájú termőhelyekröl származó Homalothecium lutescens (Hedw.) mohafajban. In: BARTHA S. \& NAGY Z. (eds): Botanikai, Növényélettani és Ökológiai Kutatások. Tuba Zoltán professzor úr emlékének. Szent István Egyetem, Gödöllő, pp. 57-64.

ERZBERger P. (2010): Racomitrium lanuginosum (Hedw.) Brid., Riccia crozalsii Levier. (In: ElLis L. T. (ed.): New national and regional bryophyte records, 25). - J. Bryol. 32(4): 317. https://doi.org/10.1179/jbr.2010.32.4.311

Galambos I. (2010): A 3. Biodiverzitás Nap (Porva) keretében gyüjtött mohok (Bryophyta). - Fol. Mus. Hist.-nat. Bakonyiensis 27: 15-18.

JAKAB G. \& SÜMEGi P. (2010): Preliminary data on the bog surface wetness from the Sirok Nyírjestó peat bog, Mátra Mts, Hungary. - Central European Geology 53(1): 43-65. https://doi.org/10.1556/ceugeol.53.2010.1.3

JAKAB G. \& SÜMEGI P. (2010): The role of bryophyte paleoecology in quaternary climate reconstructions. - In: Veress B. \& Szigethy J. (eds): Horizons in Earth Science Research. Nova Science Publishers, Washington, pp. 2-33.

JAKAB G., SÜMEgi P. \& SzURDoki E. (2010): Paleoecology of peatlands - Quaternary climate reconstructions from Hungary. - In: Veress B. \& SZIGEThy J. (eds): Horizons in Earth Science Research. Nova Science Publishers, Washington, pp. 1-33. 
KIRÁLY I. \& Ódor P. (2010): The effect of stand structure and tree species composition on epiphytic bryophytes in mixed deciduous - coniferous forests of Western Hungary. - Biol. Conservation 143(9): 2063-2069. https://doi.org/10.1016/j.biocon.2010.05.014

LÁJER K. (2010): A Devecseri-Bakonyalja növényvilága. (The vegetation of the landscape Devecseri-Bakonyalja). - Kanitzia 17: 121-150.

MARSCHALl M. (2010): Fruktántartalmú mohafajok metabolikus aktivitása különbözö környezeti tényező́k függvényében. - In: BARTHA S. \& NAGY Z. (eds): Botanikai, növényélettani és ökológiai kutatások. Tuba Zoltán professzor úr emlékének. Szent István Egyetem, Gödöllő, pp. 77-84.

Marschall M. (2010): Photosynthetic responses, carbohydrate composition and invertase activity in fructan accumulating bryophytes (Porella platyphylla and Sphagnum flexuosum) under different environmental conditions (carbohydrate treatments, dark starvation, low temperature, desiccation). - Acta Biol. Hung. 61(Suppl. 1): 120-129.

https://doi.org/10.1556/abiol.61.2010.suppl.12

Misık T. \& MisıK-BARTóк D. (2010): Új tőzegmoha előfordulás a Mátrában. - Kitaibelia 15(12): 180.

Orbán S. (2010): Moha stratégia-ökológiai kutatások. - In: Botanika Hete, Eszterházy Károly Főiskola, 2010., Eger, p. 3.

PAPP B. (2010): Néhány aktuális adat Pécs környékének érdekes, ritka moháiról - egy fontos mohavédelmi terület kijelölése. (Some actual data about the valuable, rare bryophytes from the surrounding of Pécs - selection of an IBrA (Important Bryophyte Area)). - Dunántúli Dolg. Term. Tud. Sorozat 12: 42-50.

Papp B., Erzberger P., Ódor P., Hock Zs., Szövényi P., Szurdoki E. \& Tóth Z. (2010): Updated checklist and red list of Hungarian bryophytes. - Studia bot. hung. 41: 31-59.

PAPP B., Ódor P. \& SZURDoKI E. (2010): Bryophyte biodiversity monitoring system in Hungary, Eastern Central Europe. - In: International Academic Memorial Issue for Prof. Pan-Chieh. Nanjing Normal University. Nanjing Normal University Press, Nanjing, pp. 95-111.

Sass-Gyarmati A., Molnár K., Vojt Kó A. \& Dulai S. (2010): Bryophyte and lichen species collected by Antal Margittai found in the Herbarium of Eger (EGR). - In: ANDRIK E. (ed.): Bicentenary of vegetation cover studies of the Carpathians: Proceedings of International Scientific Conference devoted to the 130th anniversary since Antal Margittai's birthday. Karpaty, Uzhhorod, pp. 220-226.

Sass-Gyarmati A. \& Vojt Kó A. (2010): The herbarium of the botanical department in Károly Eszterházy College (Eger). - Acta Biol. Plant. Agr. 1(1): 7-13.

SZARVAS V.E., TAKÁCs A. \& NAGY M. (2010): A Debreceni Egyetem Herbáriumának mohagyüjteménye. (The bryophyte-collection of the University of Debrecen). - Kitaibelia 15(1-2): 65-72.

SZURDOKI E., Ódor P., TímÁR G. \& TóTH Z. (2010): A Fias-tó és az azt körülvevő cseres-kocsányos tölgyesek bemutatása. - In: MolnÁr Cs., Molnár Zs. \& VARGA A. (eds): „Hol az a táj szab az életnek teret, Mit az Isten csak Jókedvében teremt.”: Válogatás az első tizenhárom MÉTAtúrafüzetből. 2003-2009. - MTA ÖBKI, Vácrátót, pp. 149-154.

SzÜcs P. (2010): A Naszály mohaflórája. - In: Pin TÉR B. \& Tím ÁR G. (eds): A Naszály természetrajza. Rosalia 5. Duna-Ipoly Nemzeti Park Igazgatóság, Budapest, pp. 177-216.

SzÜcs P. (2010): Jövevény mohafajok Európában és Magyarországon. - manuscript (PhD theses), NymE EMK, Roth Gyula Erdészeti- és Vadgazdálkodási Tudományok Doktori Iskola, Sopron, $21 \mathrm{pp}$.

SzŰcs P. \& BidLó A. (2010): A Phaeoceros carolinianus (Michx.) Proskauer és a Riccia glauca L. előfordulása és termőhelye Öriszentpéternél. - Kitaibelia 15(1-2): 181. 


\section{1}

Bednarek-Ochyra H., Erzberger P. \& Ochyra R. (2011): Bucklandiella microcarpa (Hedw.) Bednarek-Ochyra \& Ochyra. (In: ElLis L. T. (ed.): New national and regional bryophyte records, 29). - J. Bryol. 33(4): 317-318. https://doi.org/10.1179/1743282011Y.0000000031

JAKAB G. \& SÜMEGI P. (2011): The role of bryophyte paleoecology in quaternary climate reconstructions. - In: Tuba Z., Slack N. G. \& Stark L. R. (eds): Bryophyte ecology and climate change. Cambridge University Press, London, pp. 335-357.

Kevey B., Ódor P., Szurdoki E., BARTha D., TímÁr G. \& Bölöni J. (2011): Jla - Füzlápok. - In: BölöNi J., MolnÁr Zs. \& KUn A. (eds): Magyarország Élőhelyei. Vegetációtípusok leírása és határozója: ÁNÉR 2011. MTA Ökológiai és Botanikai Kutatóintézet, Vácrátót, pp. 208-211.

MARSChall M. \& BorbéLy P. (2011): Photosynthetic responses of the desiccation intolerant Sphagnum angustifolium in relation to increasing its desiccation tolerance by exogenous ABA. - Acta Biol. Szeged. 55(1): 119-121.

Németh Cs. \& PAPp B. (2011): Mannia triandra in the Transdanubian Mountain Range (Hungary). - Studia bot. hung. 42: 23-29.

Ódor P., Szurdoki E. (2011): Hookeria lucens (Hedw.) Sm. (In: Ellis L. T. (ed.): New national and regional bryophyte records, 26). - J. Bryol. 33(1): 68. https://doi.org/10.1179/1743282010Y.0000000014

Ódor P., Szurdoki E., KeVey B. \& Riezing N. (2011): J1b - Nyírlápok, nyíres tözegmohalápok. - In: BölöNi J., MolnÁr Zs. \& KUn A. (eds): Magyarország Élőhelyei. Vegetációtípusok leírása és határozója: ÁNÉR 2011. - MTA Ökológiai és Botanikai Kutatóintézet, Vácrátót, pp. 234-237.

Ódor P., SZurdoki E., Rédei T., Bölöni J., Bodonczi L. \& LÁjer K. (2011): C23 - Tözegmohás átmeneti lápok és tözegmohalápok. - In: BölöNi J., Molnár Zs. \& KUN A. (eds): Magyarország Élőhelyei. Vegetációtípusok leírása és határozója: ÁNÉR 2011. - MTA Ökológiai és Botanikai Kutatóintézet, Vácrátót, pp. 71-75.

Ódor P., Tinya F., Márialigeti S., Mag Zs. \& Király I. (2011): A faállomány és különböző erdei élőlénycsoportok kapcsolata az örségi erdőkben. (Connection between stands and different organism groups in the forests of Örség (Western Hungary)). - Erdészeti Lapok 146(1): 23-26.

Orbán S. (2011): Acidofil erdók moháinak diverzitása. - In: Orbán S. \& ANTAL K. (eds): Magyar Tudomány Ünnepe 2011. - Előadások, 2011.11.09., EKF, TTK, Eger, p. 4.

Pócs T. (2011): Signs of climate changes in the bryoflora of Hungary. - In: TUBA Z., SLACK N. G. \& STARK L. R. (eds): Bryophyte ecology and climate change. Cambridge University Press, Cambridge, pp. 359-370. https://doi.org/10.1017/cbo9780511779701.019

SzÜCs P., Fodor A. \& BALOGH L. (2011): Adatok Nyugat-Magyarország mohaflórájához, a Savaria Múzeum gyüjteménye alapján. - Savaria, Vas Megy. Múz. Értesitöje 34(1): 9-25.

\section{2}

BARThA D. (2012): A magyarországi védett mohák ismertetése. - In: BARTHA D. (ed.): Természetvédelmi növénytan. - Mezőgazda Kiadó, Budapest, pp. 104-111.

Désamoré A., Laenen B., STech M., Papp B., Hedenäs L., Mateo R. \& Vanderpoorten A. (2012): How do temperate bryophytes face the challenge of a changing environment? Lessons from the past and predictions for the future. - Global Change Biology 18(9): 2915-2924. https://doi.org/10.1111/j.1365-2486.2012.02752.x 
ERzBerger P. (2012): Project plan: bryophyte mapping of Hungary. - In: 8th Conference of European Committee for Conservation of Bryophytes, Bryophyte conservation follow up on the 2010 biodiversity target. European Committee for Conservation of Bryophytes, The Hungarian Natural History Museum, p. 12.

Fogarasi G., NAgy J. Gy., Péli E., Csintalan Zs. \& Tóth Zs. (2012): A kiszáradás-türés szerepe két Sphagnum faj zonációjában. (The role of desiccation tolerance of two Sphagnum species in their zonation). - Kitaibelia 17(1): 24.

Fogarasi G., Nagy J., Péli E., Csintalan Zs. \& Tóth Zs. (2012): Kiszáradás utáni feléledésmenet egy zsombéktetön és egy semlyékben élö tözegmohán. - In: BARTHA S. \& MÁzsA K. (eds): 9. Magyar Ökológus Kongresszus Keszthely, 2012. szeptember 5-7. Programfüzet. Előadások és poszterek összefoglalói, 9. Magyar Ökológus Kongresszus, MTA ÖK Ökológiai és Botanikai Intézet, p. 44.

Jámbor I., Papp M., Lökös L., Papp B., Novák T., Kovásznai-Oláh R., Kovács Z. \& Matus G. (2012): Adatok nyirségi mészkerülo" nyillt homoki gyep szervezödéséhez és dinamikájához. - In: Bartha S. \& MÁzsA K. (eds): 9. Magyar Ökológus Kongresszus Keszthely, 2012. szeptember 5-7. Programfüzet. Előadások és poszterek összefoglalói, 9. Magyar Ökológus Kongresszus, MTA ÖK Ökológiai és Botanikai Intézet, p. 57.

Kalo M. \& Tóтн Z. (2012): A Balaton-felvidéki Fekete-hegy flórája és élőhelytípusai. (The flora and habitats of Fekete-hegy (Balaton-felvidék, Hungary). - Kitaibelia 17(1): 107.

MARSCHALL M. (2012): Fotoszintézis adaptációk mohafajokban az élőhelyi fényviszonyok, a morfológia és a kiszáradástürésük vonatkozásában. - In: BARTHA S. \& MÁzsA K. (eds): 9. Magyar Ökológus Kongresszus Keszthely, 2012. szeptember 5-7. Programfüzet. Előadások és poszterek összefoglalói, 9. Magyar Ökológus Kongresszus, MTA ÖK Ökológiai és Botanikai Intézet, p. 69.

MÁrton O., SzÖvÉNyi P. \& SZURdoki E. (2012): A Sphagnum recurvum fajcsoport morfológiai és genetikai vizsgálata Európában. (Morphological and genetical investigation of Sphagnum recurvum group in Europe). - Kitaibelia 17(1): 117.

Misik T. \& Misık-BARTók D. (2012): Distribution of Sphagnum quinquefarium in Hungary. Short comments. - Acta Biol. Plant. Agr. 2: 97-99.

ÓdOR P., KIRÁLY I. \& MÁRIALIGETI S. (2012): Effect of stand structure on the diversity of epiphytic and ground-floor bryophytes assemblages in Hungarian mixed forests. - In: 8th Conference of European Committee for Conservation of Bryophytes, Bryophyte conservation follow up on the 2010 biodiversity target. European Committee for Conservation of Bryophytes, The Hungarian Natural History Museum, p. 24.

ORBÁN S. (2012): Adatok a debreceni Nagyerdő mohaflórájához. - Calandrella 15: 73-75.

OrBáN S. (2012): Kriptogámok (gombák, zuzmók, mohák) védelmének alakulása Magyarországon az elmúlt évtizedekben. - In: Kiss Cs. (ed.): 1972-2012. Ember és Bioszféra Konferencia, 2012.02.22., Eger, p. 4 .

PAPP B. (2012): Mohavédelem a XXI. században. - TermészetBúvár 67(4): 36-38.

PAPP B. (2012): The Hungarian Biodiversity Research Society and some bryological results of the Biodiveristy Days in 2011. - In: 8th Conference of European Committee for Conservation of Bryophytes, Bryophyte conservation follow up on the 2010 biodiversity target. European Committee for Conservation of Bryophytes, The Hungarian Natural History Museum, pp. 26-27.

Papp B., Erzberger P., Ódor P., Hock Zs., Szövényi P., Szurdoki E. \& Tóth Z. (2010): Red list of Hungarian bryophytes. - In: 8th Conference of European Committee for Conservation of Bryophytes, Bryophyte conservation follow up on the 2010 biodiversity target. European Committee for Conservation of Bryophytes, The Hungarian Natural History Museum, p. 25. 
PAPP B., Ódor P. \& SzURdoki E. (2012): Mohaközösségek-monitorozása a Budai Sas-hegyen különös tekintettel az orgonairtások hatásaira - In: KÉzDY P. \& TóTH Z. (eds): Természetvédelem és kutatás a Sas-hegyen. Rosalia 8. Duna-Ipoly Nemzeti Park Igazgatóság, Budapest, pp. 129-139.

PAPp B. \& TóTh Z. (2012): A Sas-hegy mohaflórája - jelen és múlt. - In: KÉZDy P. \& TóTH Z. (eds): Természetvédelem és kutatás a Sas-hegyen. Rosalia 8. Duna-Ipoly Nemzeti Park Igazgatóság, Budapest, pp. 179-188.

PÉNZES-KóNYA E. (2012): Case study of vegetative regeneration: a perspective way for ex situ conservation of bryophytes. - In: 8th Conference of European Committee for Conservation of Bryophytes, Bryophyte conservation follow up on the 2010 biodiversity target. European Committee for Conservation of Bryophytes, The Hungarian Natural History Museum, p. 27.

RABNECZ Gy. (2012): Különbözzö tér- és időléptékü mohabioindikációs vizsgálatok Magyarországon és a trópusokon. - Doktori értekezés tézisei, Gödöllö, 11 pp.

Sabovljević M., Papp B., Vujičić M., Szurdoki E., Segarra-Moragues J.G. \& Sabovljević A. (2012): In vitro micropropagation of rare and endangered moss Entosthodon hungaricus (Funariaceae). - Biosci.J. 28(4): 632-640.

SCHRöder W. \& ERZberger P. (2012): Bryum subapiculatum Hampe. (In: Ellis L. T. (ed.): New national and regional bryophyte records, 31). - J. Bryol. 34(2): 124. https://doi.org/10.1179/1743282012Y.0000000009

SZAKÁLY Á. \& TóTH Z. (2012): Szőce község és a szöcei tőzegmohás láprétek. (The history of Szőce village and the Sphagnum meadows). - Kitaibelia 17: 142.

SzÜcs P. \& BIDló A. (2012): Számithatunk-e jövevény mohafajok inváziójára Magyarországon? - In: Bartha S. \& Mázsa K. (eds): 9. Magyar Ökológus Kongresszus Keszthely, 2012. szeptember 5-7. Programfüzet. Előadások és poszterek összefoglalói, 9. Magyar Ökológus Kongresszus, MTA ÖK Ökológiai és Botanikai Intézet, p. 102.

SzÜcs P. \& Bidló A. (2012): Orthodontium lineare Schwägr. In: Ellis L.T. (ed.): New national and regional bryophyte records, 33. - J. Bryol. 34(4): 281-291. https://doi.org/10.1179/1743282012Y.0000000030

Tóтн E., Fodor A. \& Tóтн Z. (2012): Egy őrségi láposodó erdeifenyves tőzegmohaflórájának feltárása. (Investigations of the Sphagnums in a damp pine forest in Őrség (W Hungary)). Kitaibelia 17(1): 149.

\section{3}

Bodorné JuHÁsz A. \& Csintalan Zs. (2013): A Syntrichia ruralis mohafaj szénmegkötése, ökofiziológiai és növekedési sajátosságai. - In: PÉNZESNÉ KóNYA E. (ed.): II. Aktuális eredmények a kriptogám növények kutatásában Konferencia, Eger, p. 27.

Csiky J., PURger D. \& Csikyné R. É. (2013): A Riccietum rhenanae Knapp et Stoffers 1962 elöfordulása Magyarországon. (The Riccietum rhenanae Knapp et Stoffers 1962 in Hungary). - Kitaibelia 18(1-2): 129-135.

ERzberger P. \& NÉMETH Cs. (2013): Mohatérképezés Magyarországon - eredmények az iniciális fázisból. - In: PÉNZESNÉ KóNYA E. (ed.): II. Aktuális eredmények a kriptogám növények kutatásában Konferencia. Eger, p. 13.

ERzberger P. \& SCHRöder W. (2013): The genus Bryum (Bryaceae, Musci) in Hungary. - Studia bot. hung. 44: 5-192.

JAKAB G. (2013): A fosszilis mohák szerepe a negyedidőszaki paleobotanikai kutatásokban. - In: PÉNZESNÉ KóNYA E. (ed.): II. Aktuális eredmények a kriptogám növények kutatásában Konferencia, Eger, p. 7. 
Király I., NAsCimbene J., Tinya F. \& Ódor P. (2013): Factors influencing epiphytic bryophyte and lichen species richness at different spatial scales in managed temperate forests. - Biodiversity and Conservation 22(1): 209-223. https://doi.org/10.1007/s10531-012-0415-y

LöKös L., PAPP B. \& MATUS G. (2013): Bükki mészkő sziklagyep kriptogám vegetációja nagyvad elöl elzárt és legelt állományban. - In: PÉNZESNÉ KóNYA E. (ed.): II. Aktuális eredmények a kriptogám növények kutatásában Konferencia, Eger, p. 22.

MARSCHALL M. (2013): Fotoszintézis adaptációk mohafajokban az éloohelyi fényviszonyok, a morfológia és a kiszáradás türésük vonatkozásában. - In: PÉnZesné KóNYA E. (ed.): II. Aktuális eredmények a kriptogám növények kutatásában Konferencia, Eger, p. 14.

Marschall M., TOMKU E. \& BorbéLy P. (2013): Photosynthetic activity, the induction of photosynthesis and photoprotective mechanisms of the desiccation-intolerant (Sphagnum angustifolium) during desiccation/rehydration cycles, after darkness and ABA-hardening. - In: BLAN KENSHIP R. E. \& ORT D. R. (eds): 16th International Congress of Photosynthesis Research. St. Louis (MO), USA, p. 248.

Ódor P., Király I., Tinya F., Bortignon F. \& Nascimbene J. (2013): Epifiton mohák és zuzmók faji összetételét és diverzitását meghatározó tényezök az örségi erdökben. - In: PÉNZESNÉ KóNYA E. (ed.): II. Aktuális eredmények a kriptogám növények kutatásában Konferencia, Eger, p. 9.

Ódor P., Király I., Tinya F., Bortignon F. \& Nascimbene J. (2013): Patterns and drivers of species composition of epiphytic bryophytes and lichens in managed temperate forests. Forest Ecol. Manag. 306: 256-265. https://doi.org/10.1016/j.foreco.2013.07.001

Ódor P., SZURdoki E., BotTA-Dukát Z. \& PAPp B. (2013): Spatial pattern and temporal dynamics of bryophyte assemblages in saline grassland. - Folia Geobot. 48(2): 189-207. https://doi.org/10.1007/s12224-012-9140-2

Orbán S. \& Pénzes-Kónya E. (2013): Professor Tamás Pócs the record of his 80 years. - Polish Bot.J. 58(1): 3-30. https://doi.org/10.2478/pbj-2013-0001

PAPP B. (2013): Adatok a Fekete-hegy mohaflórájához. (Additons to the bryophyte flora of Fekete Hill at Szentbékkálla (Balaton-felvidék region. Hungary)). - Folia Mus. Hist.-nat. Bakonyiensis 29: 47-52.

PApp B. (2013): Pliocén korú moha-fosszília Puláról. - In: Katona L. T. (ed.): A pulai Kráter-tó. Bakonyi Természettudományi Múzeum Baráti Köre, Zirc, p. 15.

PAPP B. (2013): Új Európai Moha Vörös Könyv projekt. - In: PÉnZESné KónYA E. (ed.): II. Aktuális eredmények a kriptogám növények kutatásában Konferencia, Eger, p. 12.

PÉNZESNÉ KóNYA E. \& LAKNERFI K. (2013): Eltérö növekedésformájú talajlakó lombosmoha fajok korai vegetativv regenerációs mechanizmusainak összehasonlítása. - In: PÉNZESNÉ KóNYA E. (ed.): II. Aktuális eredmények a kriptogám növények kutatásában Konferencia, Eger, p. 19.

SZAKÁly Á., SZURDoki E. \& Tóth Z. (2013): Új adatok a szöcei láprétek tözegmoháiról. - In: PÉNZESNÉ KóNYA E. (ed.): II. Aktuális eredmények a kriptogám növények kutatásában Konferencia, Eger, pp. 10-11.

SZURDOKI E., MÁRTON O. \& SZÖVÉNYi P. (2013): A Sphagnum recurvum fajcsoport morfológiai és genetikai vizsgálata Európában. - In: PÉNZESNÉ KóNYA E. (ed.): II. Aktuális eredmények a kriptogám növények kutatásában Konferencia, Eger, p. 15.

SzÜCs P. (2013): A mohák megjelenését meghatározó egyes ökológiai tényezők vizsgálata a Sopronihegységben. - Doktori értekezés, Nyugat-magyarországi Egyetem, Sopron, 84 pp.

SzÜCs P. (2013): A neofiton Campylopus introflexus (Hedw.) Brid. újabb hazai előfordulása Tatabányánál. - Kitaibelia 18(1-2): 186.

SzÜcs P. (2013): Bükkös és lucos állományok mohaközösségeinek összehasonlitása a Soproni-hegységben. - In: PÉNZESNÉ KóNYA E. (ed.): II. Aktuális eredmények a kriptogám növények kutatásában Konferencia, Eger, p. 26. 
Szücs P. (2013): Kiegészítések a Zirci Arborétum mohaflórájához. - Folia Mus. Hist.-nat. Bakonyiensis 30(1): 47-54.

Szücs P. (2013): Mohainvázió Magyarországon? - Természet Világa 144(7): 326-327.

SzÜcs P. \& BıDLó A. (2013): Bükkös és lucos állományok mohaközösségeinek összehasonlítása a Soproni-hegységben. - Erdészettud. Közlem. 3(1): 157-166.

SzÜCs P., Németh Cs. \& Erzberger P. (2013): Adatok a Dicranum tauricum Sapjegin hazai elterjedéséhez II. (Data on the distribution of Dicranum tauricum Sapjegin in Hungary II.). - Bot. Közlem. 100(1-2): 147-154.

\section{4}

Csiky J., Atkári B., Deme J. \& Csikyné Radnai É. (2014): Mohaflorisztikai érdekességek a Nyugat-Mecsekböl. (Interesting moss and liverwort records from the Western Mecsek Mts (South Transdanubia, Hungary)). - Kitaibelia 19(1): 29-38.

Csiky J., At KÁRi B., Deme J. \& Csikyné Radnai É. (2014): Tözegmohás úszólápok a Mecsekben. - In: SChmidt D., KovÁcs M. \& BARThA D. (eds): X. Aktuális flóra- és vegetációkutatás a Kárpát-medencében nemzetközi konferencia absztraktkötete. Nyugat-magyarországi Egyetem Kiadó, Sopron, p. 146.

Csiky J., Erzberger P., Kovács D. \& Deme J. (2014): Campylopus pyriformis (Schultz) Brid. a Ny-Mecsekben. (Campylopus pyriformis (Schultz) Brid. in the Western Mecsek Mts. (South Transdanubia, Hungary)). - Kitaibelia 19(2): 366-367.

ERzBeRger P. (2014): Encalypta rhaptocarpa Schwaegr. (In: Ellis L. T. (ed.): New national and regional bryophyte records, 39). - J. Bryol. 36(2): 140. https://doi.org/10.1179/1743282014Y.0000000100

Erzberger P. \& Meinunger L. (2014): Cephaloziella varians (Gottsche) Stephani var. varians (In: Ellis L. T. (ed.): New national and regional bryophyte records, 39). - J. Bryol. 36(2): 138. https://doi.org/10.1179/1743282014Y.0000000100

Erzberger P. \& Meinunger L. (2014): Scapania praetervisa Meyl. (In: Ellis L. T. (ed.): New national and regional bryophyte records, 39). - J. Bryol. 36(2): 144. https://doi.org/10.1179/1743282014Y.0000000100

Erzberger P. \& Németh Cs. (2014): Campylopus flexuosus (Hedw.) Brid. (In: Ellis L. T. (ed.): New national and regional bryophyte records, 39). - J. Bryol. 36: 137-138. https://doi.org/10.1179/1743282014Y.0000000100

ERZBerger P. \& NÉMETH Cs. (2014): Új faj Magyarország mohaflórájában: Campylopus flexuosus (Hedw.) Brid. (Campylopus flexuosus (Hedw.) Brid.: a moss new to the Hungarian bryophyte flora). - Kitaibelia 19(1): 22-28.

Farkas E. (2014): In honour of the 80 years old Tamás Pócs. - Acta Bot. Acad. Sci. Hung. 56(1-2): 1-7. https://doi.org/10.1556/abot.56.2014.1-2.1

Fodor A. \& Szurdoki E. (2014): Dél-Dunántúl tőzegmohás élőhelyei. (Sphagnum habitats in south-west of Hungary). - Természetvéd. Közlem. 20: 24-49.

Hedenäs L., Désamoré A., Laenen B., Papp B., Quandt D., González-Mancebo J. M., PATIÑO J. VANDERPOORTEN A. \& STECH M. (2014): Three species for the price of one within the moss Homalothecium sericeum s.l. - Taxon 63(2): 249-257.

https://doi.org/10.12705/632.16

Heilmann-Clausen J., Aude E., van Dort K., Christensen M., Piltaver A., Veerkamp M., Walleyn† R., Siller I., Standovár T. \& Ódor P. (2014): Communities of woodinhabiting bryophytes and fungi on dead beech logs in Europe - reflecting substrate quality or shaped by climate and forest conditions? - J. Biogeogr. 41(12): 2269-2282.

https://doi.org/10.1111/jbi.12388 
Katona L., Kutasi Cs., Papp B. \& Tóth S. (2014): Újabb szenzációs őslénytani leletek a pulai alginitbányából (Further remarkable palaeontological finds at the alginite quarry in Pula). Annls hist.-nat. Mus. natn. Hung. 106: 117-140.

KöVENDI-JAKÓ A. \& ÓDOR P. (2014): A moha propagulum bank és a felszini mohavegetáció összehasonlítása az örségi erdőkben. - In: LENG YEL Sz. (ed.): IX. Magyar Természetvédelmi Biológiai Konferencia „Tudományoktól a döntéshozatalig” Absztrakt-kötet. Magyar Biológiai Társaság, Budapest, Szegedi Tudományegyetem Ökológiai Tanszék, MTA Ökológiai Kutatóközpont, Szeged, p. 77.

Nagy J. Gy., Fogarasi G., Tóth Zs., Fogarasi G., Endrédi A., Kissné Uzonyi Á. \& CserhalMI D. (2014): Egy hajdan tözegmohás észak-alföldi láp vegetációjának húsz éves fejlódése. In: Schmidt D., Kovács M. \& BARThA D. (eds): X. Aktuális flóra- és vegetációkutatás a Kárpát-medencében nemzetközi konferencia absztraktkötete. Nyugat-magyarországi Egyetem Kiadó, Sopron, pp. 50-51.

NÉMETH Cs. \& ERZBERger P. (2014): A Bakony mohaflórája. - In: „A Bakony Biodiverzitása” konferencia, Zirc, Absztraktkötet, p. 4.

ÓDOR P. (2014): A korhadó faanyag szerepe az erdei növények biodiverzitásában. - Silva Naturalis 5: $155-170$

Ódor P., Kutszegi G., Papp V., Guba E., József J. \& Benedek L. (2014): Az erdögazdálkodás holtfa viszonyokra és szaproxil biodiverzitásra gyakorolt hatása a Mátrában. - In: LENGYEL Sz. (ed.): IX. Magyar Természetvédelmi Biológiai Konferencia „Tudományoktól a döntéshozatalig” Absztrakt-kötet. Magyar Biológiai Társaság, Budapest, Szegedi Tudományegyetem Ökológiai Tanszék, MTA Ökológiai Kutatóközpont, Szeged, p. 96.

Papp B., Németh Cs., Erzberger, P., Ódor P. \& Szurdoki E. (2014): Védett mohafajok újabb adatai az MTM Mohaherbáriuma alapján. - In: Lengyel Sz. (ed.): IX. Magyar Természetvédelmi Biológiai Konferencia „Tudományoktól a döntéshozatalig” Absztrakt-kötet. Magyar Biológiai Társaság, Budapest, Szegedi Tudományegyetem Ökológiai Tanszék, MTA Ökológiai Kutatóközpont, Szeged, p. 99.

PAPp B., ÓDor P. \& SzURDoKi E. (2014): Sziklai illatosmoha, Zöld koboldmoha, Zöld seprömoha. (Mannia triandra, Buxbaumia viridis, Dicranum viride). - In: HARAszthy L. (ed.): NATURA 2000 fajok és élőhelyek Magyarországon. Pro Vértes Közalapítvány, Csákvár, pp. 22-30.

PAPP B. \& SzURdoKi E. (2014): Új Európai Moha Vörös Könyv projekt magyar vonatkozásai. In: Schmidt D., Kovács M. \& BARTHA D. (eds): X. Aktuális flóra- és vegetációkutatás a Kárpát-medencében nemzetközi konferencia absztraktkötete. Nyugat-magyarországi Egyetem Kiadó, Sopron, pp. 37-38.

Papp B., Szurdoki E., Lockhart N. \& Hodgetts N. (2014): Készülőben az új Európai Moha Vörös Könyv. (The new red data book of European bryophytes in preparation). - Annls hist.nat. Mus. natn. Hung. 106: 157-168.

SZURdoki E., MÁrton O. \& SZÖvénYi, P. (2014): Genetic and morphological diversity of Sphagnum angustifolium, S. flexuosum, S. fallax in Europe. - Taxon 63(2): 237-248. https://doi.org/10.12705/632.6

SzÜcs P. (2014): A Dicranum tauricum Sapjegin (Musci, Dicranaceae) elterjedése a Fenyőfői Ösfenyvesben. - Folia Mus. Hist.-nat. Bakonyiensis 31(1): 39-46.

SzÜCs P., BöRCsöK Z. \& KÁMÁN O. (2014): A Riccia glauca L. és a Riccia sorocarpa Bisch. elöfordulása Barcs belterületén. (Occurrence of Riccia glauca L. and Riccia sorocarpa Bisch. in town of Barcs). - Kitaibelia 19(2): 365.

SzÜcs P., CsıKy J. \& PAPp B. (2014): A neofiton Campylopus introflexus (Hedw.) Brid. elterjedése Magyarországon. (Distribution of Campylopus introflexus (Hedw.) Brid. in Hungary). Kitaibelia 19(2): 212-219. 
SzÜcs P. \& Patocskai Z. (2014): Adatok a Fenyőfői Ösfenyves mohaflórájához. - Folia Mus. Hist.-nat. Bakonyiensis 31(1): 25-38.

\section{5}

Balogh R., Béregi B., Saraiva M. L., Novák T., Lökös L., Papp B., Varga N. \& Matus G. (2015): Moha - zuzmó - mikrogomba közösség összetétele és biomasszája legelt és kizárt mészkerülö nyílt homoki gyepben. - In: SzŰcs P. \& PÉNZESNÉ KóNYA E. (eds): III. Aktuális eredmények a kriptogám növények kutatásában. A konferencia előadásainak és posztereinek összefoglalói. Eszterházy Károly Főiskola, Eger, p. 12.

Barina Z., Benedek L., Boros L., Dima B., FolCz Á., Király G., Koszka A., Malatinszky Á., PAPp D., PıfKó D. \& PAPP V. (2015): Taxonomical and chorological notes 1 (1-19). Studia bot. hung. 46(2): 205-221. https://doi.org/10.17110/StudBot.2015.46.2.205

Csiky J. \& Deme J. (2015): Egy terjeszkedö faj, a Dicranum tauricum Sapjegin sporofitonos állományai Magyarországon. - In: SzÜcs P. \& PÉnZesné KónYA E. (eds): III. Aktuális eredmények a kriptogám növények kutatásában. A konferencia előadásainak és posztereinek összefoglalói. Eszterházy Károly Főiskola, Eger, p. 37.

Csiky J., Erzberger, P., Kovács D. \& Deme J. (2015): Campylopus flexuosus (Hedw.) Brid. Nyugat-Mecsekben.(Campylopus flexuosus (Hedw.) Brid. in the Western Mecsek Mts. (South Transdanubia, Hungary). - Kitaibelia 20(1): 28-37. https://doi.org/10.17542/kit.20.28

Deme J., Csiky J. \& ERzBerger P. (2015): Campylopus fragilis (Brid.) Bruch \& Schimp. (In: ELLIS L. T. (ed.): New national and regional bryophyte records, 43.). - J. Bryol. 37(2): 131-132. https://doi.org/10.1179/1743282015Y.0000000003

Deme J., Kovács D., Tüzes D. \& Csı́xy J. (2015): A magyarországi Campylopus fajok élőhhelypreferenciája a Mecsekben. - In: SzŰCs P. \& PÉnZesné KónYa E. (eds): III. Aktuális eredmények a kriptogám növények kutatásában. A konferencia előadásainak és posztereinek összefoglalói. Eszterházy Károly Főiskola, Eger, p. 15.

Deme J., SZekeres P. \& Csiky J. (2015): A pécsi egyetemi herbárium (JPU) mohagyüjteményének digitális adatbázisa. - In: SzŰCs P. \& PÉNZESNÉ KóNYA E. (eds): III. Aktuális eredmények a kriptogám növények kutatásában. A konferencia előadásainak és posztereinek összefoglalói. Eszterházy Károly Főiskola, Eger, p. 38.

ERzBERGer P. (2015): Bryum barnesii J. B. Wood es Schimp. (In: Ellis L. T. et al. (ed.): New national and regional bryophyte records, 45.). - J. Bryol. 37(4): 310. https://doi.org/10.1179/1743282015Y.0000000035

ERzberger P. \& Németh Cs. (2015): A magyarországi szisztematikus mohatérképezés legújabb eredményei. - In: SZŰCs P. \& PÉNZESNÉ KóNYA E. (eds): III. Aktuális eredmények a kriptogám növények kutatásában. A konferencia előadásainak és posztereinek összefoglalói. Eszterházy Károly Főiskola, Eger, p. 17.

Erzberger P. \& NÉmeth Cs. (2015): Campylium decipiens (Warnst.) Walsem. (In: Ellis L. T. (ed.): New national and regional bryophyte records, 45.). - J. Bryol. 37: 313-314. https://doi.org/10.1179/1743282015Y.0000000035

Erzberger P., Németh Cs., Papp B., Mesterházy A., Csiky J. \& Baráth K. (2015): Revision of the red list status of hungarian Bryophytes 1 . New occurrences of species Previously thought to be regionally extinct or without recent data. - Studia bot. hung. 46(2): 15-53.

https://doi.org/10.17110/studbot.2015.46.2.15

JAKAB G. (2015): A magyarok mohája. - A Földgömb 33(294): 18.

Kovács A. \& Rigó A. (2015): A Budai Arborétum moba-és zuzmóflórája. - manuscript (TDK thesis), Budapesti Corvinus Egyetem, Kertészettudományi Kar, Növénytani Tanszék és Soroksári Botanikus kert, 30 pp. 
Laufer Zs., Dulai S. \& Csintalan Zs. (2015): Eltérő kitettségü élőhelyről származó kriptobiotikus kérgek mohakomponenseinek szezonális ökofiziológiai vizsgálata. - In: SzüCs P. \& PÉNZESNÉ KóNYA E. (eds): III. Aktuális eredmények a kriptogám növények kutatásában. A konferencia előadásainak és posztereinek összefoglalói. Eszterházy Károly Főiskola, Eger, p. 21.

Laufer Zs., Dulai S., Veres K. \& Csintalan Zs. (2015): Seasonal dynamics of photosynthetic thermal stability and xanthophyll cycle pigments in some moss and lichen components of cryptobiotic crusts exposed at different habitat in Bugac, Hungary. - In: Costa VIEIRA C. et al. (eds): XX. Simposio de Botánica Criptogámica: Book of Abstracts. Universidade do Porto, Porto, p. 120.

Liktor-Busa E., Urbán E., Zupkó I., Szücs P. \& Csupor D. (2015): In vitro antibacterial and antiproliferative screening of Hungarian bryophytes. - Planta Medica 81(16): 1442. https://doi.org/10.1055/s-0035-1565443

Lökös L., Varga N., Sass-Gyarmati A., Kerényi-Nagy V. \& Pócs T. (2015): $A$ budapesti Vöröskö-vár Prunetalia cserjéseiben termö kriptogámok. (Cryptogams of Prunetalia shrubs on the Vöröskö-vár(Budapest)). In: Kerényi-Nagy V., Szirmai O., Helyes L., Penksza K. \& NemÉNyi A. (eds): „I. Rózsa- és Galagonya-konferencia a Kárpát-medencében” Nemzetközi konferencia 2015. május 29-30, Gödöllő. Konferencia-kötet. Szent István Egyetemi Kiadó, Gödöllő, pp. 233-234.

MarSCHAll M. \& SüTő Sz. (2015): Különböző mértékü kiszáradásnak alávetett Porella platyphylla újranedvesedést követö fiziológiai regenerációjának sajátosságai. - In: PADIsÁK J., LIKER A. \& Stenger-KovÁcs Cs. (eds): X. Magyar Ökológus Kongresszus. Pannon Egyetem, Veszprém, 2015. augusztus 12-14., p. 106.

MARSCHALL M. \& SÜTö Sz. (2015): Újranedvesedés alatti fényvédelmi és regenerációs mechanizmusok háttérfolyamatainak, komponenseinek vizsgálata kiszáradástürő és kiszáradásérzékeny mohafajokban. - In: Szücs P. \& PÉNZEsné KóNYA E. (eds): III. Aktuális eredmények a kriptogám növények kutatásában. A konferencia előadásainak és posztereinek összefoglalói. Eszterházy Károly Főiskola, Eger, p. 24.

Mák O. K., MÁRTON O. \& SZURDOKI E. (2015): A Sphagnum recurvum fajcsoport morfológiai vizsgálata. - In: SzÜcs P. \& PÉnzesné KónYA E. (eds): III. Aktuális eredmények a kriptogám növények kutatásában. A konferencia előadásainak és posztereinek összefoglalói. Eszterházy Károly Főiskola, Eger, p. 42.

Mesterházy A. \& Németh Cs. (2015): Bruchia flexuosa (Schwägr.) Müll. Hal. (In: Ellis L. T. et al. (ed.): New national and regional bryophyte records, 45). - J. Bryol. 37(4): 310-311. https://doi.org/10.1179/1743282015Y.0000000035

Németh Cs. \& Erzberger P. (2015): Anacamptodon splachnoides (Amblystegiaceae): Hungarian populations of a moss species with a peculiar habitat. - Studia bot. hung. 46(1): 61-75. https://doi.org/10.17110/studbot.2015.46.1.61

NÉmeth Cs. \& Mesterházy A. (2015): Bruchia flexuosa (Schwägr.) Müll. Hal.: egy igazi különlegesség a magyar mohaflórában. (Bruchia flexuosa (Schwägr.) Müll. Hal. a true peculiarity in the Hungarian bryoflora). - Kitaibelia 20(2): 193-201. https://doi.org/10.17542/kit.20.193

Ódor P. \& Kovács B. (2015): Lophocolea heterophylla májmoha túlélése, különböző mikroklímatikus feltételeket biztositó erdészeti beavatkozások után. - In: SzÜCs P. \& PÉNZESNÉ KóNYA E. (eds): III. Aktuális eredmények a kriptogám növények kutatásában. A konferencia előadásainak és posztereinek összefoglalói. Eszterházy Károly Főiskola, Eger, p. 26.

Ódor P., Papp V., Kutszegi G., Németh Cs., Szücs P., Guba E., József J. \& Benedek L. (2015): Az erdögazdálkodás holtfa viszonyokra és szaproxyl biodiverzitásra gyakorolt hatása az Északi középhegységben. - In: PAdisáx J., Liker A. \& STEnger-Kovács Cs. (eds): X. Magyar Ökológus Kongresszus. Pannon Egyetem, Veszprém, 2015. augusztus 12-14., p. 163. 
Saboljevic M., Papp B., Szurdoki E., Vujičic M., Saboljevic A. \& Ódor P. (2017): Eredmények az ex situ moha védelem területén szerb-magyar akadémiai együttmüködés keretében. - In: SzÜCs P. \& PÉnzesné KónYA E. (eds): III. Aktuális eredmények a kriptogám növények kutatásában. A konferencia előadásainak és posztereinek összefoglalói. Eszterházy Károly Föiskola, Eger, p. 30.

SÜTö Sz. \& MARSCHALL M. (2015): Abiotikus stresszfaktorok hatásainak fénymikroszkópos vizsgálata Porella platyphylla sejtekben. - In: SzÜCs P. \& PÉnZEsné KónYA E. (eds): In: SzÜcs P. \& PÉNZESNÉ KóNYA E. (eds): III. Aktuális eredmények a kriptogám növények kutatásában. A konferencia előadásainak és posztereinek összefoglalói. Eszterházy Károly Főiskola, Eger, p. 32.

SzURDOKI E., ÓDOR P. \& PAPP B. (2017): Sziklagyepi mohaközösségek dinamikájának vizsgálata a Nemzeti Biodiverzitás-monitorozó Rendszer keretében. - In: SzÜcs P. \& PÉNZESNÉ KóNYA E. (eds): III. Aktuális eredmények a kriptogám növények kutatásában. A konferencia előadásainak és posztereinek összefoglalói. Eszterházy Károly Főiskola, Eger, p. 34.

SzÜCs P. (2015): A Pterygoneurum squamosum Segarra et Kürschner előfordulása egy Győr melletti rekultivált hulladéklerakón. (The occurrence of Pterygoneurum squamosum Segarra et Kürschner on a reclaimed waste storage near town Győr (NW Hungary)). - Kitaibelia 20(1): 23-27. https://doi.org/10.17542/kit.20.23

SzÜcs P. (2015): Kindbergia praelonga (Hedw.) Ochyra Sopron város mohaflórájában. (Kindbergia praelonga (Hedw.) Ochyra in the urban bryoflora of the town of Sopron (W Hungary)). - Kitaibelia 20(2): 305. https://doi.org/10.17542/kit.20.300

SzŰCs P. (2015): Mohaflorisztikai vizsgálatok az egykori almásfüzitői timföldgyár környékén. (Bryofloristial studies in an abandoned alumina refinery near Almásfüzitő, NW Hungary (a case study)). - Kitaibelia 20(2): 206-212. https://doi.org/10.17542/kit.20.206

SzÜcs P., József J., PApp V. G. \& Kutszegi G. (2015): A veszélyeztetett Anacamptodon splachnoides (Froel. ex Brid.) Brid. új adata a Bükk-hegységből. (A new record of the threatened Anacamptodon splachnoides (Froel. ex Brid.) Brid. from the Bükk Mts. (NE Hungary)). Kitaibelia 20(2): 202-205. https://doi.org/10.17542/kit.20.202

SZÜCs P. \& PÉNZESNÉ KóNYA E. (2015): Mohadiverzitás vizsgálatok Almásfüzitőn. - In: SzüCs P. \& PÉNZESNÉ KóNYA E. (eds): III. Aktuális eredmények a kriptogám növények kutatásában. A konferencia előadásainak és posztereinek összefoglalói. Eszterházy Károly Főiskola, Eger, p. 47.

SzÜcs P., SснміDт D. \& CsiszÁr Á. (2015): Kiegészítések a Soproni-hegység mohaflórájához II. (Contribution to the bryoflora of Sopron Hills (W Hungary) II.). - Kitaibelia 20(1): 59-66. https://doi.org/10.17542/kit.20.59

\section{6}

Balogh R., Béregi B., Saraiva M. L., Novák T., Lökös L., Papp B., Varga N. \& Matus G. (2016): Kriptogám közösség összetétele és biomasszája legelt és kizárt nyírségi Corynephoretum gyepben. (In: Barina Z. (ed.): Növénytani Szakülések). - Bot. Közlem. 103(1): 176.

Baráth K., Erzberger P., Kovács A. \& PAPp B. (2016): Heterocladium dimorphum (Heterocladiaceae, Bryophyta) - an old element of the Hungarian bryophyte flora rediscovered. Studia bot. hung. 47(2): 269-278. https://doi.org/10.17110/StudBot.2016.47.2.269

Caparrós R., Lara F., Draper I., MAzimpaka V. \& Garilleti, R. (2016): Integrative taxonomy sheds light on an old problem: the Ulota crispa complex (Orthotrichaceae, Musci). - Bot. J. Linn. Soc. 180(4): 427-451. https://doi.org/10.1111/boj.12397

Deme J., Erzberger P., Kovács D., Lökös L., Németh Cs., Ódor P., Papp B., Tóth I. Zs. \& CsıKY J. (2016): A levéltelen koboldmoha (Buxbaumia aphylla) magyarországi elterjedése és élöhelyi preferenciája. (Distribution and habitat preference of Buxbaumia aphylla in Hungary). 
- In: Barina Z., Buczkó K., Lő kös L., PApp B., Pif kó D., Szurdoki E. (eds): XI. Aktuális flóra- és vegetációkutatás a Kárpát-medencében nemzetközi konferencia Előadások és poszterek összefoglalói. Magyar Természettudományi Múzeum, Budapest, pp. 31-33.

Erzberger P. (2016): Fissidens crispus Mont. (In: Ellis L. T. (ed.): New national and regional bryophyte records, 48). - J. Bryol. 38(3): 243-244. https://doi.org/10.1080/03736687.2016.1206685

ERzBERGER P. (2016): Mooskartierung in Ungarn. - Herzogiella 3: 40-46.

ERzberger P. (2016): The genus Fissidens (Fissidentaceae, Bryophyta) in Hungary. - Studia bot. hung. 47(1): 41-139. https://doi.org/10.17110/StudBot.2016.47.1.41

Erzberger P., Bednare K-Ochyra H. \& Ochyra R. (2016): Grimmiaceae subfam. Racomitrioideae (Bryophyta) in Hungary. - Polish Bot. J. 61(1): 23-51.

https://doi.org/10.1515/pbj-2016-0015

ERZBERGER P. \& NÉMETH Cs. (2016): Bryophyte recording in Hungary - results 2012-2015 (Mohatérképezés Magyarországon - a 2012 és 2015 közötti periódus eredményei). - In: BARINA Z., Buczkó K., Lökös L., PApp B., Pifkó D., Szurdoki E. (eds): XI. Aktuális flóra- és vegetációkutatás a Kárpát-medencében nemzetközi konferencia Előadások és poszterek összefoglalói. Magyar Természettudományi Múzeum, Budapest, pp. 29-30.

Erzberger P., Németh Cs. \& Mesterházy A. (2016): Callicladium haldanianum (Grev.) H. A. Crum. (In: Ellis L. T. (ed.): New national and regional bryophyte records, 47). - J. Bryol. 38(2): 153-154. https://doi.org/10.1080/03736687.2016.1171453

Erzberger P. \& SCHRöder W. (2016): Bryum tenuisetum Limpr. (In: Ellis L. T. (ed.): New national and regional bryophyte records, 47). - J. Bryol. 38: 152-153. https://doi.org/10.1080/03736687.2016.1171453

FARkas E., Lőkös L., PAPp B., Sinigla M. \& VARgA N. (2016): Zuzmók és mohák biodiverzitásvizsgálata a Szigligeti Kongó-rétek mintaterületen. (Biodiversity of bryophytes, lichen-forming and lichenicolous fungi on "Kongó Meadows" (Hegymagas-Szigliget, Hungary)). - Fol. Mus. Hist.-nat. Bakonyiensis 33: 19-33.

JAкав G. \& SüMegi P. (2016): Ingoványos terepen: Tőzeglápok mélyén. - A Földgömb 34(306): $34-45$.

Kövendi-Jakó A., Márialigeti S., Bidló A. \& Ódor, P. (2016): Environmental drivers of the bryophyte propagule bank and its comparison with forest-floor assemblage in Central European temperate mixed forests. - J. Bryol. 38(2): 118-126. https://doi.org/10.1080/03736687.2015.1115804

Nagy Z., Majláth I., Molnár M. \& Erzberger P. (2016): Martonvásári kastélypark mohaflórája. (Bryofloristical study in the Brunszvik manor park in Martonvásár, Hungary). Kitaibelia 21(2): 198-206. https://doi.org/10.17542/kit.21.198

Németh Cs. (2016): Ditrichum lineare (Sw.) Lindb. (In: Ellis L. T. (ed.): New national and regional bryophyte records, 48). - J. Bryol. 38(3): 242-243. https://doi.org/10.1080/03736687.2016.1206685

Németh Cs., Kovács A. \& Erzberger P. (2016): Seligeria acutifolia Lindb. (In: Ellis L. T. (ed.): New national and regional bryophyte records, 49.). - J. Bryol. 38(4): 340. https://doi.org/10.1080/03736687.2016.1225777

Németh Cs. \& NAgY J. (2016): Barbilophozia hatcheri (Evans) Loeske. (In: Ellis L. T. (ed.): New national and regional bryophyte records, 49.). - J. Bryol. 38(4): 329. https://doi.org/10.1080/03736687.2016.1225777

Németh Cs. \& PAPP B. (2016): Mohák a Soroksári Botanikus kertben. - In: HöHN M. \& PAPP V. (eds): Biodiverzitás a Soroksári Botanikus kertben, Kriptogámok: Gombák, zuzmók, mohák, harasztok. Magyar Biodiverzitás-kutató Társaság \& SZIE Kertészettudományi kar Soroksári Botanikus kert, Budapest, pp. 111-150. 
ÓDor P. (2016): Az erdei biodiverzitást meghatározó tényezö́k az Örségi Nemzeti Parkban. Természetvédelmi biológiai esettanulmány sok élólénycsoport figyelembe vételével. - In: KORDA M. (ed.): Az erdőgazdálkodás hatása az erdők biológiai sokféleségére. Duna-Ipoly Nemzeti Park Igazgatóság, Budapest, pp. 603-624.

ÓDOR P. (2016): Erdögazdálkodás hatása az erdei moha- és zuzmóközösség biodiverzitására. - In: KordA M. (ed.): Az erdőgazdálkodás hatása az erdők biológiai sokféleségére. Duna-Ipoly Nemzeti Park Igazgatóság, Budapest, pp. 57-70.

SÜtö Sz. \& Marschall M. (2016): Light microscopic study of Porella platyphylla (L.) Pfeiff. cells under various abiotic stress factors. - Acta Biol. Plant. Agr. 4: 89-106. https://doi.org/10.21406/abpa.2016.4.89

SzǗcs P. \& PÉNZes-KónYa E. (2016): Mohaadatok az Eszterházy Károly Főiskola Botanikus Kertjéből (Eger). - Acta Acad. Paed. Agr., Sect. Biol. 43(1): 53-57.

\section{7}

BALOGH R. (2017): Kriptogám közösség összetétele és biomasszája nyírségi Corynephoretum eltérö kezelésü részein. - In: MÁNDY Zs. (ed.): Inter Talent Unideb, Absztrakt összefoglalók. Debreceni Egyetem, Debrecen, pp. 18-19.

Balogh R., Farkas E., Lökös L., Papp B., Budai J., Antal K., Novák T. \& Matus G. (2017): Mosses and lichens in dynamics of acidic sandy grasslands: specific response to grazing exclosure. (Mohák és zuzmók legelés kizárásra adott válasza savanyú homoki gyepekben). Acta Biol. Plant. Agr. 5(1): 30. https://doi.org/10.21406/abpa.2017.5.1.30

Baráth K. (2017): A preliminary study of bryophytes in the Pinka Gorge. - Studia bot. hung. 48(1): 67-76. https://doi.org/10.17110/StudBot.2017.48.1.67

BARÁth K. \& Erzberger P. (2017): A mohaflóra terepi felmérésének első eredményei a Kőszegi hegységben (In: BARINA Z. (ed.): Növénytani szakülések). - Bot. Közlem. 104(1): 166-167.

Baráth K. \& Erzberger P. (2017): The bryoflora of the Pinka Gorge. A Pinka-szurdok mohaflórája. - Acta Biol. Plant. Agr. 5(1): 48. https://doi.org/10.21406/abpa.2017.5.1.48

BARÁth K. \& ERZberger P. (2017): Heterocladium heteropterum (Brid.) Schimp. (In: Ellis L. T. (ed.): New national and regional bryophyte records, 50). - J. Bryol. 39(1): 104-105. https://doi.org/10.1080/03736687.2016.1259931

Baráth K. \& Erzberger P. (2017): Plagiothecium latebricola Schimp. (In: Ellis L. T. (ed.): New national and regional bryophyte records, 52). - J. Bryol. 39(3): 293. https://doi.org/10.1080/03736687.2017.1341752

Baráth K., Erzberger P., Deme J. \& Csiky J. (2017): Remarkable results of recent field explorations in the Köszeg Mts. - Acta Biol. Plant. Agr. 5(1): 31. https://doi.org/10.21406/abpa.2017.5.1.33

BARINA Z. (2017): Peter Erzberger and the journal Studia botanica hungarica. - Studia bot. hung. 48(1): 5-20. https://doi.org/10.17110/StudBot.2017.48.1.

Csiky J., Kovács D., Deme J., Takács A., Óvári M., Molnár V. A., Malatinszky Á., Nagy J. \& BARINA Z. (2017): Taxonomical and chorological notes 4 (38-58). - Studia bot. hung. 48(1): 133-144. https://doi.org/10.17110/studbot.2017.48.1.133

Csupor D., Szücs P. \& MARsch All M. (2017): Gyógyító mohák. - Természetbúvár 72(2): 44-46.

Csupor D., Vollár M., Zupkó I., Csupor B., Marschall M., SzÜcs P. \& Urbán E. (2017): Bryophytes as potential source of secondary metabolites with anti-proliferative and antimicrobial activities. - Int. J. Phytocosm. Nat. Ingredients 5: 30. 
Deme J., Erzberger P., Kovács D., Baráth K., Lantos I., Magos G., Nagy J., Nagy K., Nagy Z., Németh Cs., Ódor P., PApp B., Tóth I. Zs. \& Csiky J. (2017): Distribution and habitat preference of Buxbaumia Hedw. species in Hungary. - Acta Biol. Plant. Agr. 5(1): 32.

https://doi.org/10.21406/abpa.2017.5.1.32

Eckstein J., NAgy J. \& Erzberger P. (2017): Sciuro-hypnum curtum (Lindb.) Ignatov. (In: ElLIS L. T. (ed.): New national and regional bryophyte records, 53). - J. Bryol. 39: 378. https://doi.org/10.1080/03736687.2017.1384204

Erzberger P., BARÁth K. (2017): Plagiothecium latebricola Schimp., a new member of the Hungarian bryoflora. - Studia bot. bung. 48 (2): 189-197. https://doi.org/10.17110/StudBot.2017.48.2.189

Erzberger P., Németh Cs., Nagy J., Baráth K., Csiky J., Eckstein J., Mesterházy A., Kovács A. \& PAPP B. (2017): Remarkable finds of bryophytes in Hungary during the last two years (2015-2017). - Acta Biol. Plant. Agr. 5(1): 33. https://doi.org/10.21406/abpa.2017.5.1.33

Köckinger H. \& HedenÄs L. (2017): A farewell to Tortella bambergeri (Pottiaceae) as understood over the last decades. - J. Bryol. 39(3): 213-225. https://doi.org/10.1080/03736687.2017.1307313

MARSCHALL M. (2017): Ecophysiology of bryophytes in the changing environment: Moha-ökofiziológia a változó környezetben. - Acta Biol. Plant. Agr. 5(1): 34. https://doi.org/10.21406/abpa.2017.5.1.34

Marschall M. (2017): Ecophysiology of bryophytes in a changing environment. - Acta Biol. Plant. Agr. 5(2): 61-70. https://doi.org/10.21406/abpa.2017.5.1.34

Marschall M., Borbély P. \& Sütő Sz. (2017): Újranedvesedés alatti fényvédelmi és regenerációs mechanizmusok háttérfolyamatainak, komponenseinek vizsgálata kiszáradástürö és kiszáradásérzékeny mohafajokban. - In: GyöRGYEY J. (ed.): A Magyar Növénybiológiai Társaság XII. Kongresszusa 2017. augusztus 30. - szeptember 1. Szeged, MTA Szegedi Biológiai Kutatóközpont. Program. Összefoglalók. A Magyar Növénybiológiai Társaság, Szeged, p. 15.

Marschall M., Szücs P., Bárdos B., Hilyákné Kadlott M., Tóth B. \& Csupor D. (2017): In vitro micropropagation of 4 Hungarian bryophytes as potential sources for pharmacologically active substrates: Farmakológiailag ígéretes 4 hazai mohafaj in vitro mikroszaporítása. - Acta Biol. Plant. Agr. 5(1): 53. https://doi.org/10.21406/abpa.2017.5.1.53.

Mesterházy A., BAráth K. \& Erzberger P. (2017): Rhabdoweisia crispata (Dicks. ex With.) Lindb. (In: Ellis L. T. (ed.): New national and regional bryophyte records, 50). - J. Bryol. 39(1): 107. https://doi.org/10.1080/03736687.2016.1259931

Mesterházy A., Matus G., Király G., Szücs P., Török P., Valkó O., Pelles G., Papp V. G., Virók V., Nemcsok Z., Rigó A., Hohla M. \& Barina Z. (2017): Taxonomical and chorological notes 5 (59-70). - Studia bot. hung. 48 (2): 263-275. https://doi.org/10.17110/StudBot.2017.48.2.263

NAGY J. \& ERZBERGER P. (2017): Current results of bryophyte mapping of Börzsöny Mts (Hungary). (A Börzsöny hegység mohatérképezésének aktuális eredményei). - Acta Biol. Plant. Agr. 5(1): 35. https://doi.org/10.21406/abpa.2017.5.1.35

Nagy J. \& Németh Cs. (2017): A Pseudoleskea saviana (De Not.) Latzel lombosmoha Magyarországon. (Distribution of Pseudoleskea saviana (De Not.) Latzel in Hungary). - Kitaibelia 22(2): 272-285. https://doi.org/10.17542/kit.22.272

NAGy K., Deme J. \& CsiKy J. (2017): Distribution and habitat preference of Leucobryum Hampe species in the Mecsek Mts. (Hungary). - Acta Biol. Plant. Agr. 5(1): 55.

https://doi.org/10.21406/abpa.2017.5.1.55 
NÉmeth Cs. (2017): Biodiversity of bryophilous Pezizales in Hungary. - Acta Biol. Plant. Agr. 5(1): 36. https://doi.org/10.21406/abpa.2017.5.1.36

NÉMETH Cs. (2017): Briomikológiai kutatások Magyarországon. In: VI. Magyar Mikológiai Konferencia, Szeged. Absztraktkötet. - Mikol. Közlem., Clusiana 56(1): 42-44.

NÉMETH Cs. (2017): Octospora erzbergeri (Pyronemataceae), a bryophilous ascomycete in Hungary. - Studia bot. hung. 48(1): 105-123. https://doi.org/10.17110/StudBot.2017.48.1.105

NÉMETH Cs., ECKSTEIN J. \& STÖCKLI E. (2017): New European occurrences of Neottiella ricciae, a bryophilous ascomycete. - Herzogia 30(2): 353-361. https://doi.org/10.13158/heia.30.2.2017.353

ÓDOR P. (2017): Effect of forest management on bryophyte communities - a review. (Az erdőgazdálkodás hatása a mohaközösségekre - áttekintés). - Acta Biol. Plant. Agr. 5(1): 28. https://doi.org/10.21406/abpa.2017.5.1.28

PApp B. \& Sinigla M. (2017): Zygodon forsteri (Dicks.) Mitt. (In: Ellis L. T. (ed.): New national and regional bryophyte records, 52.). - J. Bryol. 39(3): 297. https://doi.org/10.1080/03736687.2017.1341752

PAPP B. \& SZURDOKIE. (2017): A Káli-medence környéki hegyek mohaflorisztikai feltárása.(Survey on the bryophyte flora of mountains surrounding Káli Basin (Balaton-felvidék Region, Hungary)). - Acta Biol. Plant. Agr. 5(1): 58. https://doi.org/10.21406/abpa.2017.5.1.58

Patiño J., Hedenäs L., Dirkse M. G., Ignatov S. M., Papp B., Müller F., González-ManCEBo M. J. \& VANDERPoorten A. (2017): Species delimitation in the recalcitrant moss genus Rhynchostegiella (Brachytheciaceae). - Taxon 66(2): 293-308. https://doi.org/10.12705/662.1

Pénzes-Kónya E., Pócs T. \& Sass-Gyarmati A. (2017): In celebration of Prof. Dr. Sándor Orbán: a tribute to 45 years in bryology. - Acta Biol. Plant. Agr. 5(1): 3-25.

https://doi.org/10.21406/abpa.2017.5.1.3

Saboljevic M., Szurdoki E., Saboljevic A. \& Papp B. (2017): Back to Hungary: A story on reintroduction of a European Habitat Directive moss species, Hamatocaulis vernicosus. (Visszatérés Magyarországra: egy közösségi jelentőségű mohafaj, a Hamatocaulis vernicosus visszatelepítési kísérlete). - Acta Biol. Plant. Agr. 5(1): 60. https://doi.org/10.21406/abpa.2017.5.1.60

Sass-Gyarmati A., Pénzes-Kónya E., Kapi D., Stefancsi K G. \& Kelecsényi F. (2017): Bryophyte collection of Eszterházy Károly University (EGR): The digital database of peat moss (Sphagnum) species. - Acta Biol. Plant. Agr. 5(1): 61. https://doi.org/10.21406/abpa.2017.5.1.61

SZURDOKI E. (2017): Water chemical relations and water table of North Hungarian mires. - Studia bot. hung. 48(2): 199-224. https://doi.org/10.17110/studbot.2017.48.2.199

SZurdoki E., Érdiné Szekeres R., KoczKa K., Böhm A., Molnár A. \& Hubayné Horváth N. (2017): Hungary. - In: Joosten H., TANneberger F. \& Moen A. (eds): Mires and peatlands of Europe: Status, distribution and conservation. Schweizerbart Science Publishers, Stuttgart, pp. 432-440.

SZURDOKI E., Ódor P. \& PAPP B. (2017): Az NBmR keretében zajló moha monitorozás történeti áttekintése. - In: Mizsei E. \& Szepesváry Cs. (eds): XI. Magyar Természetvédelmi Biológiai Konferencia „Sikerek és tanulságok a természetvédelemben”. Absztrakt kötet. Magyar Biológiai Társaság, MTA Ökológiai Kutatóközpont, Eger, pp. 144.

Szücs P. (2017): Az inváziós Campylopus introflexus (Hedw.) Brid lombosmoha aktuális hazai elterjedése és aljzati preferenciája. - In: Mizsei E. \& SzePesváry Cs. (eds): XI. Magyar Természetvédelmi Biológiai Konferencia „Sikerek és tanulságok a természetvédelemben”. Absztrakt kötet. Magyar Biológiai Társaság, MTA Ökológiai Kutatóközpont, Eger, pp. 145-146. 
SzÜcs P. (2017): Bryophyte flora of the Botanic Garden of the University of Sopron (W Hungary). - Studia bot. hung. 48(1): 77-88. https://doi.org/10.17110/StudBot.2017.48.1.77

SzÜcs P. \& BALOGH L. (2017): Adatok a Ság hegy mohaflórájához. - Vasi Szemle 71(5): 622-628.

SzÜCs P., BARANYI G. \& ZöLleI T. (2017): Az Erdőtelki Arborétum mohaflorisztikai vizsgálatának elözetes eredményei. - Acta Acad. Paed. Agr., Sect. Biol. 44(1): 121-126.

SzÜCs P., PÉnZes-KónYa E. \& Hofmann T. (2017): The bryophyte flora of the village of Almásfüzitő, a former industrial settlement in NW-Hungary. - Cryptog., Bryol. 38(2): 153-170. https://doi.org/10.7872/cryb/v38.iss2.2017.153

SZÜCs P., TÁborSKÁ J., BARANYi G. \& PÉnZES-KónYA E. (2017): Short-term changes in the bryophyte flora in the botanical garden of Eszterházy Károly University (Eger, NE Hungary). Acta Biol. Plant. Agr. 5(2): 52-60. https://doi.org/10.21406/abpa.2017.5.2.52

TÁborská M., Procházková J., Lengyel A., VRŠKA T., Hort L. \& Ódor P. (2017): Woodinhabiting bryophyte communities are influenced by different management intensities in the past. - Biodiversity and Conservation 26(12): 2893-2909. https://doi.org/10.1007/s10531-017-1395-8

VADAS Á., KovÁcs B. \& ÓDOR P. (2017): The effect of different forest management types on the survival rate of epixylic and epiphytic bryophytes. (Epifiton és epixyl mohafajok túlélésének kísérletes vizsgálata különböző erdészeti kezelések során). - Acta Biol. Plant. Agr. 5(1): 45. https://doi.org/10.21406/abpa.2017.5.1.45

Vollár M., Szücs P., Marschall M., Zupkó I., Gyovai A., Csupor-Löffler B. \& Csupor D. (2017): Hazai mohafajok fitokémiai és farmakológiai vizsgálata. - In: CsUpor D., RÉDEI D. \& Kiss T. (eds): Fiatal Gyógynövénykutatók Fóruma: A Magyar Gyógyszerésztudományi Társaság Gyógynövény Szakosztályának tudományos konferenciája: Absztraktfüzet. Budakalász, Magyarország, 2017. p. 10. https://doi.org/10.14232/fgykf.2017.b1

Zsólyom D. \& Szücs P. (2017): Preliminary results of bryofloristical investigations in Balaton village (NE-Hungary). (Balaton község mohaflorisztikai vizsgálatának kezdeti eredményei). - Acta Biol. Plant. Agr. 5(1): 64. https://doi.org/10.21406/abpa.2017.5.1.64

\section{8}

Alegro A., Šegota V., Papp B., Deme J., Kovács D., Purger D. \& Csiky J. (2018): The invasive moss Campylopus introflexus (Hedw.) Brid. (Bryophyta) spreads further into south-eastern Europe. - Cryptog., Bryol. 39(3): 331-341. https://doi.org/10.7872/cryb/v39.iss3.2018.331

Burrascano S., de Andrade R. B., Paillet Y., Ódor P., Antonini G., Bouget C., Campagnaro T., Gosselin F., Janssen P., Persiani A. M., Nascimbene J., Sabatini F. M., Sitzia T. \& BLASI C. (2018): Congruence across taxa and spatial scales: are we asking too much of species data? - Global Ecol. Biogeogr. 27(8): 980-990. https://doi.org/10.1111/geb.12766

Deme J., Erzberger P., Kovács D. \& Csiky J. (2018): A Mecsek hegység mohatérképezésének aktuális eredményei. (Recent results of bryophyte mapping in the Mecsek Mts (Hungary)). - In: Molnár V. A., Sonkoly J. \& TAKács A. (eds): Program és összefoglalók. XII. Aktuális flóra- és vegetációkutatás a Kárpát-medencében nemzetközi konferencia. Debreceni Egyetem, TTK, Növénytani Tanszék, Debrecen, p. 61.

ERZBERger P. (2018): Fossombronia incurva Lindb. (In: Ellis L. T. (ed.): New national and regional bryophyte records, 54). - J. Bryol. 40(1): 81 . https://doi.org/10.1080/03736687.2018.1425573

Erzberger P. (2018): Pellia neesiana (Gottsche) Limpr. (In: Ellis L. T. (ed.): New national and regional bryophyte records, 54). - J. Bryol. 40(1): 84.

https://doi.org/10.1080/03736687.2018.1425573 
Erzberger P., Baráth K. \& Gallego M. T. (2018): Syntrichia ruralis (Hedw.) F. Weber \& D. Mohr var. epilosa (Venturi) J. J. Amann. (In: Ellis L. T. (ed.): New national and regional bryophyte records, 57). - J. Bryol. 40: 412. https://doi.org/10.1080/03736687.2018.1523601

Erzberger P., Németh Cs., Baráth K. \& Mesterházy A. (2018): Sematophyllum adnatum (Michx.) E. Britton. (In: Ellis L. T. (ed.): New national and regional bryophyte records, 54). - J. Bryol. 40(1): 89. https://doi.org/10.1080/03736687.2018.1425573

Erzberger P., Németh Cs., Deme J. \& Csiky J. (2018): Stomatal anatomy allows clarification of historical collections of Buxbaumia species in Hungary. - Studia bot. hung. 49(1): 71-82. https://doi.org/10.17110/StudBot.2018.49.1.71

ERzBerger P. \& PAPp B. (2018): Tortella fasciculata and T. pseudofragilis (Pottiaceae, Bryophyta) in Hungary. - Studia bot. hung. 49(2): 39-48. https://doi.org/10.17110/studbot.2018.49.2.39

Kučera J., Blockeel T. L., Erzberger P., Papp B., Soldán Z., Vellak K., Werner O. \& M. Ros R. (2018): The Didymodon tophaceus complex (Pottiaceae, Bryophyta) revisited: new data support the subspecific rank of currently recognized species. - Cryptog., Bryol. 39(2): 241-257. https://doi.org/10.7872/cryb/v39.iss2.2018.241

Marschall M., Borbély P., PÉnzesné KónYa E. \& SÜTö Sz. (2018): Background processes and the components of photoprotection and regeneration under rehydration in desiccation-tolerant and desiccation-sensitive bryophytes. - In: University of Copenhagen (ed.): Plant Biology Europe 2018 Conference: Abstract Book. Department of Plant and Environmental Sciences, University of Copenhagen, Copenhagen, p. 80.

Matus G., Csiky J., Bauer N., Baráth K., Vasuta G., Barabás A., Hricsovinyi D., Takács A., Antal K., Budai J., Erzberger P., Molnár P. \& Barina Z. (2018): Taxonomical and chorological notes 7 (75-84). - Studia bot. hung. 49(2): 83-94.

https://doi.org/10.17110/StudBot.2018.49.2.83

Nagy J. \& Erzberger P. (2018): Crossidium squamiferum (Viv.) Jur. (In: Ellis L. T. (ed.): New national and regional bryophyte records, 55.). - J. Bryol. 40(2): 176-177. https://doi.org/10.1080/03736687.2018.1454161

NAGy J. \& PAPp B. (2018): A Grimmia plagiopodia Hedw. természetvédelmi helyzete Magyarországon. Conservational status of Grimmia plagiopodia Hedw. in Hungary. - In: Molnár V. A., SON KOLY J. \& TAKÁcs A. (eds): Program és összefoglalók. XII. Aktuális flóra- és vegetációkutatás a Kárpát-medencében nemzetközi konferencia. Debreceni Egyetem, TTK Növénytani Tanszék, Debrecen, p. 81.

NAGY J. \& PAPP B. (2018): A Grimmia plagiopodia Hedw. természetvédelmi helyzete Magyarországon. (Conservational status of Grimmia plagiopodia Hedw. in Hungary). - Kitaibelia 23(2): 133-140. https://doi.org/10.17542/kit.23.133

Ódor P., Aszalós R., Boros G., Elek Z., Kovács B., Samu F., Sass V., Tinya F., Tóth B. \& VADAS Á. (2018): Erdészeti fahasználatok termőhelyre, biodiverzitásra és felújulásra gyakorolt hatásának kisérletes vizsgálata. - In: 11. Magyar Ökológus Kongresszus, Nyíregyháza, 2018. augusztus 28-30. Absztraktkötet, Magyar Ökológusok Tudományos Egyesülete, Nyíregyháza, p. 60.

Palotai B. (2018): A Vácrátóti Nemzeti Botanikus Kert moháinak ismételt térképezése. - Szent István Egyetem, Kertészettudományi Kar, Növénytani Tanszék és Soroksári Botanikus Kert. (szakdolgozat).

PAPp B. \& SzURDoki E. (2018): Bryophyte flora of the forests of Vétyem and Oltárc protected areas (Zala County, W Hungary). - Studia bot. hung. 49(1): 83-96. https://doi.org/10.17110/studbot.2018.49.1.83

PAPP B. \& SzURDoki E. (2018): Védett mohafajok új populációi a Balaton-felvidéki Nemzeti Park területén és védelmük lehetöségei. (New populations of protected bryophytes in the territory of 
the Balaton-felvidék National Park and their conservation management). - In: MolNÁR V. A., Sonkoly J. \& TAKÁcs A. (eds): Program és összefoglalók. XII. Aktuális flóra- és vegetációkutatás a Kárpát-medencében nemzetközi konferencia. Debreceni Egyetem, TTK, Növénytani Tanszék, Debrecen, p. 12.

PÉli E. R., NAgy J. Gy. \& Cserhalmi D. (2018): Tözegmohafajok diverzitás viszonyainak változásai a semlyék-zsombék relációban, kiszáradás toleranciájuk függvényében. - In: 11. Magyar Ökológus Kongresszus, Nyíregyháza, 2018. augusztus 28-30. Absztraktkötet, Magyar Ökológusok Tudományos Egyesülete, Nyíregyháza, p. 99.

SChmotzer A., TÁвors KÁ J. \& SzÜcs P. (2018): A bükkaljai oligocén kavicson kialakult mészkerüló tölgyesek társulástani viszonyai. (Acidophilous oak forests developed on Oligocenic gravel on the Bükkfoothills). - In: Molnár V. A., Sonkoly J. \& TAKács A. (eds): Program és összefoglalók. XII. Aktuális flóra- és vegetációkutatás a Kárpát-medencében nemzetközi konferencia. Debreceni Egyetem, TTK, Növénytani Tanszék, Debrecen, p. 86.

SzÜCs P. (2018): Hernád menti kunhalmok mohaflorisztikai felmérésének eredményei. (Survey of the bryophyte flora of the kurgans along the river Hernád). - In: MOLNÁR V. A., SONKOLY J. \& TAKÁcs A. (eds): Program és összefoglalók. XII. Aktuális flóra- és vegetációkutatás a Kárpát-medencében nemzetközi konferencia. Debreceni Egyetem, TTK, Növénytani Tanszék, Debrecen, p. 92.

SzÜCs P. (2018): New data on the distribution of Campylopus introflexus (Hedw.) Brid. in Hungary. - Acta Biol. Plant. Agr. 6: 133-139. https://doi.org/10.21406/abpa.2018.6.133

SzÜCS P., BARANYI G. \& Fint HA G. (2018): The bryophyte flora of the park of Mátrai Gyógyintézet Sanatorium (NE Hungary). - Acta Biol. Plant. Agr. 6: 123-132. https://doi.org/10.21406/abpa.2018.6.123

SZURDoki E. \& MÁRTON O. (2018): A Sphagnum recurvum fajcsoport morfológiai vizsgálata. - In: Csontos P., Hanga Z., Hajdu T., Korsós Z., Kovács-Hostyánszki A., Mecsnóber M., Szurdoki E. \& Vitályos G. Á. (eds): A Magyar Biológiai Társaság XXXI. Vándorgyűlése: összefoglalók. Fővárosi Állat- és Növénykert, Magyar Biológiai Társaság, Budapest, pp. 23-24.

Vollár M. \& CsUPor D. (2018): Hazai mohafajok fitokémiai és farmakológiai vizsgálata. - In: Csupor D., RÉDEI D. \& KISs T. (eds): Fiatal Gyógynövénykutatók Fóruma: A Magyar Gyógyszerésztudományi Társaság Gyógynövény Szakosztályának tudományos konferenciája. Absztraktfüzet. Szeged, Magyarország, 2018, p. 6. https://doi.org/10.14232/fgykf.2018.a1

Vollár M., Gyovai A., Szücs P., Zupkó I., Marschall M., Csupor-Löffler B., Bérdi P., Vecsernyés A., Csorba A., Liktor-Busa E., Urbán E. \& Csupor D. (2018): Antiproliferative and antimicrobial activities of selected bryophytes. - Molecules 23(7): 1520. https://doi.org/10.3390/molecules23071520

Vollár M., Zupkó I., Szücs P., Csupor-Löffler B., Marschall M., Kúsz N. \& Csupor D. (2018): New phenanthrenes from Paraleucobryum longifolium. - In: The 66th Annual Meeting of the Society for Medicinal Plant and Natural Product Research (GA), 2018.08.26-29., Sanghaj, Kína. PO-130.

Zsólyom D. \& Szücs P. (2018): Balaton település (Heves megye) mohaflórája. (The bryophyte flora of Balaton village (Heves county, Hungary)). - Bot. Közlem. 105(2): 231-242. https://doi.org/10.17716/botkozlem.2018.105.2.231

Összefoglaló: Munkánk célja volt, hogy összeállítsuk az 1968-2018 időszakban Magyarországon (illetve Magyarországon gyüjtött mohamintákkal) végzett mohakutatásokkal kapcsolatban 
megjelent irodalmak jegyzékét. Ennek során húsz hazai és több nemzetközi tudományos folyóirat tartalmát tekintettük át. A publikációk gyűjtésének hagyományos módszerei mellett, az általunk alkalmazott módszerek közé tartozott az online adatbázisokban való kutatás, a már publikált életrajzi bibliográfiák áttekintése, továbbá kutatók személyes megkeresése és vonatkozó publikációik bekérése. Munkánk eredményeként mintegy 835, a legkülönbözőbb típusokba (könyv, könyvrészlet, tudományos cikk, bibliográfia, absztrakt, ismeretterjesztő cikk, kézirat) tartozó közleményt gyüjtöttünk össze, amelyeket éves bontásban adunk közre.

(submitted: 16.04.2019, accepted: 22.05.2019) 